\author{
UNIVERSIDADE DE SÃO PAULO \\ FACULDADE DE CIÊNCIAS FARMACÊUTICAS \\ Programa de Pós-Graduação em Ciência dos Alimentos \\ Departamento de Alimentos e Nutrição Experimental
}

Geraniol, mas não beta-ionona ou associação desses

isoprenóides, possui atividade quimiopreventiva em ratos

submetidos a modelo de carcinogênese de cólon

Alessandra Vieira

Dissertação para obtenção do grau de

MESTRE

Orientador:

Prof. Titular Fernando Salvador Moreno

São Paulo

2007 
Ficha Catalográ fica

Elaborada pela Divisão de Biblioteca e

Documentação do Conjunto das Químicas da USP.

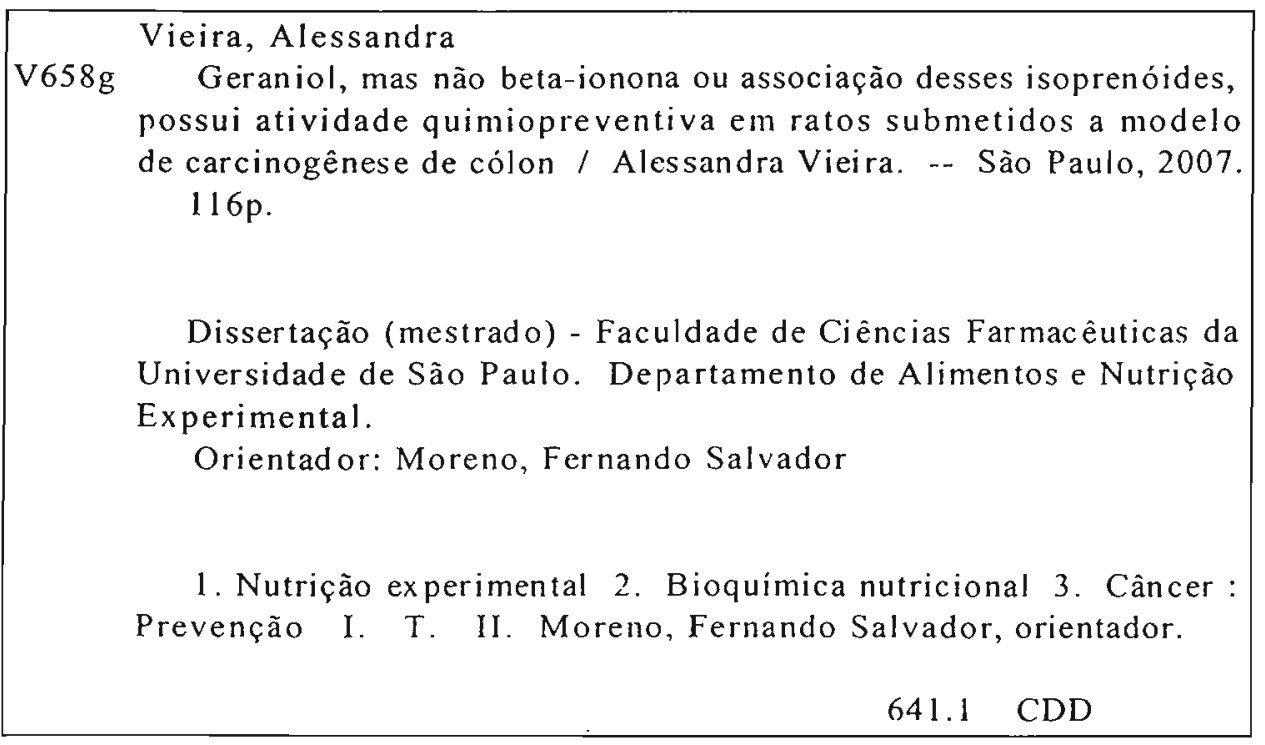




\section{Alessandra Vieira}

Geraniol, mas não beta-ionona ou associação desses isoprenóides, possui atividade quimiopreventiva em ratos submetidos a modelo de carcinogênese de cólon

Comissão Julgadora

da

Dissertação para obtenção do grau de Mestre

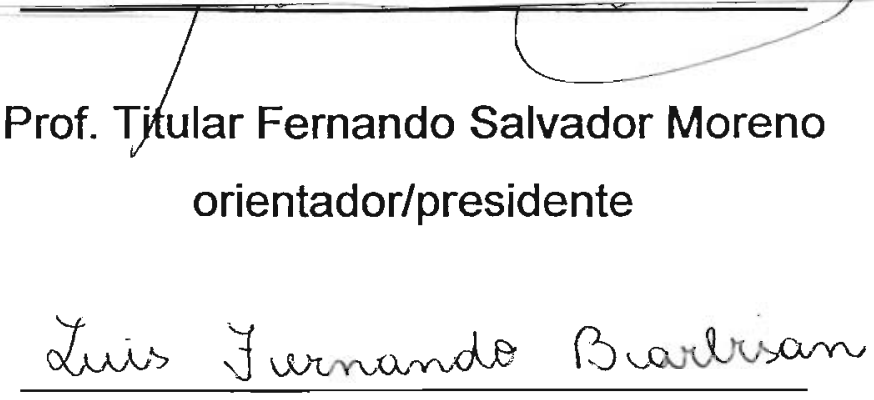

10. examinador

maria Lúcirs Zadain Dagli

2o. examinador

São Paulo, 05 de vout de 2007. 
Dedico esse trabalho à minha Família, pois ela representa a minha razão de existir e tudo o que eu tenfo de mais precioso na vida! 


\section{Agradecimentos:}

Meus sinceros agradecimentos a pessoas muito especiais e importantes em minfa vida que contribuíram tanto para o meu crescimento pessoal quanto intelectual e que possibilitaram a realizaf̧ão deste trabalho.

Agradeço, inicialmente, ao meu orientador Professor Litular Femando Saluador Moreno, não somente pela oportunidade, confiança e orientação sempre presentes, mas principalmente pela sua capacidade de estar sempre nos transmitindo o amor que sente pela pesquisa, ensinando a buscar novos confecimentos e a gostar realmente daquilo que fazemos.. Isso, com certeza, é um grande estímulo a continuarmos seguindo em frente pelo caminfio científico. Desde o inicio, meu orientador me recebeu de braços abertos e sou muito grata pela chance concedida e por todos seus ensinamentos. Biólogos são idealistas, mas tenfio certeza de que o professor Femando é bem mais do que qualquer um deles...

Agradeģo ao meu maior exemplo de mulher, minfia mãe Márcia, pelo que ela é e por ter me proporcionado a educafãa necessária à formajāo do meu caráter, por ter me guiado perante as dificuldades da vida, por sempre ter me ensinado a ser uma pessoa fonesta e cometa, a 6atalhar pelos meus objetivos e por ter feito o possivel e o impassivel para ver todos os seus filhos felizes;

Ao meu pai, Sebastiāo, que infelizmente não está mais entre nós, mas que está sempre junto de mim, de uma forma ou de outra, em minfia mente e em meu corafäo;

Aos meus imäas, Rodrigo, Marcelo e Cristiane pelo amor incondicional, profunda amizade, carinfio e respeito que nos une; pessoas com quem poderei contar para sempre, em qualquer situafāo, meus maiores amigos;

Ao Professor Doutor Thomas Prates Ong, pelas inúmeras ajudas, apoio, sugestōes e participaçōes importantes em todos os trabaftios do laboratório;

À professora Maria Lúcia Zadain Dagli da Faculdade de Medicina e Veterinária e Zootecnia USP $e$ ao professor Luis Femando Barbisan do Instituto de Biociências da Vniversidade Estadual Paulista - Unesp/Botucatu pelas valiosas contribuiçoes no meu exame de qualificação;

Aos amigos do laboratónio, pessoas incriveis, com as quais criei uma grande amizade e respeito durante todo o mestrado: Aline, Bianca, Bruna, Camila, Carlos, Clarissa, Douglas, Giuliana, Joice, Mônica, André e Letícia; obrigada pelo convívio tāo alegre e gostoso em nosso ambiente de trabalho, 
pelos momentos felizes que ficarão guardados em mintia memória para sempre. Foi um enorme prazer passar todos esses dias ao lado de pessoas tão maravifhosas...

Um agradecimento especial ao meu amigo Renato, por termos permanecidos juntos desde o início da padronizafãa desse trabalho. Enfrentamos dificuldades e, com elas, crescemos, ajudamos um ao outro, compartifhamos opiniōes, idéias, informações, enfim, fomos grandes companheiros em tudo;

A todos os funcionários, tanto do biotério, quanto do Departamento de Alimentos e $\mathcal{N u t r i c ̧ a ̄ o ~}$ Experimental que proporcionaram as condiçōes necessárias para a concretizafāo desse trabalfio;

À minfa querida amiga de infância, Samira, pela grande pessoa que é e por tudo que já vivemos juntas; por essa amizade incomparável e tão fundamental em minfia vida. Vma pessoa que, com certeza, considero uma immä;

Às minfas amigas em especial, Elaine, Jufiana (SR), Jufiana (RC) Cinthia, Betina, Bruna, pelo amor, amizade, companfeirismo, confidências, momentos alegres, difíceis e inesquecíveis que passamos todas juntas;

Aos meus amigos da Unesp de Rio Claro, que mesmo depois de formados, continuamos com grande contato e pelos quais tenfo muito carinfo e saudades dos tempos de graduação;

Ao Fenrique, uma pessoa que apareceu de surpresa na minfa vida, que se tomou muito especial $e$ que me mostrou que o tempo não é o fator mais importante para a intensidade do momento que estamos vivendo. Obrigada por todo carinfio, apoio, paciência e compreensäo nessa fase final do meu mestrado;

Às agências de fomento, CNPq, Capes, Fapesp, pela bolsa de mestrado concedida e pelo auxílio financeiro à nossa pesquỉsa;

A todas as pessoas que conviveram comigo e que participaram de alguma forma deste trabalho;

$E$, mais que tudo, agradeço a Deus pela vida que tenfio, por nunca ter me faltado nada, pelo amor presente na minfa família e nas minfias amizades e pela oportunidade que Ele está me dando de realizar meus sonfos... 
"O destino não é uma questão de sorte, é uma questão de escolha; não é algo a se esperar, é algo a se conquistar" William Jennings Bryan 
I INTRODUÇÃO

II OBJETIVOS

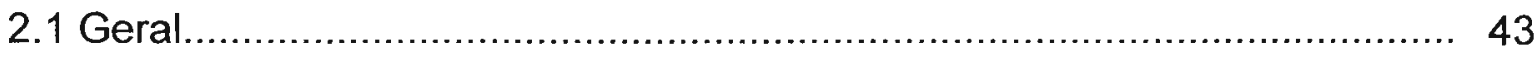

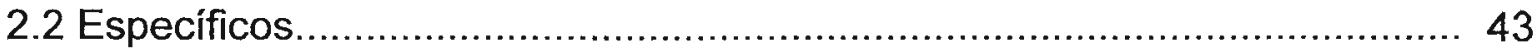

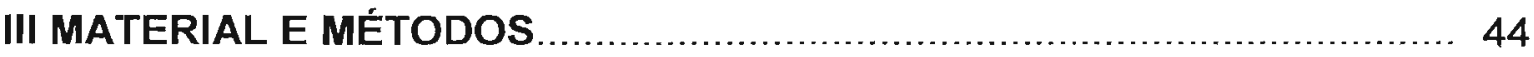

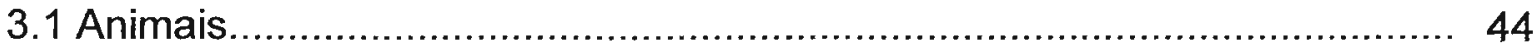

3.2 Protocolo Experimental................................................................. 44

3.3 Eutanásia dos animais e coleta do material........................................ 47

3.4 Pesquisa de Focos de Criptas Aberrantes (FCAs) ................................ 48

3.5 Determinação das Concentrações de Colesterol Plasmático Total............. 49

3.6 Avaliação de Danos no DNA da Mucosa do Cólon.................................... 50

3.7 Preparação de Extrato Protéico.............................................................. 51

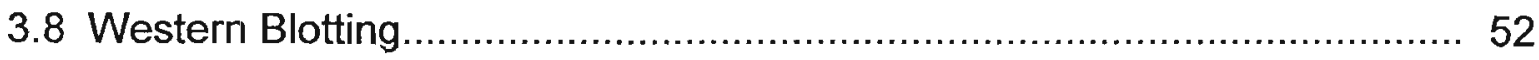

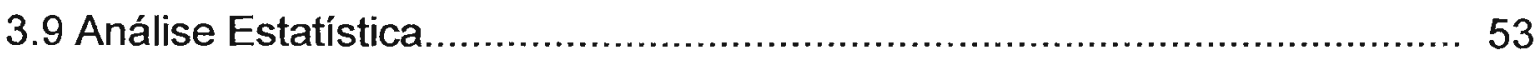

IV RESULTADOS

4.1 Peso Corpóreo e Consumo de Ração dos Animais Submetidos ao Modelo de Carcinogênese de Cólon............................................................ 54

4.2 Pesquisa de Focos de Criptas Aberrantes (FCAs) ............................... 57

4.3 Determinação das Concentrações de Colesterol Plasmático Total dos Animais Submetidos ao Modelo Experimental de Carcinogênese de Cólon..... 61 4.4 Avaliação de Danos no DNA Colônico dos Animais................................... 63

4.5 Expressão de $\mathrm{Bcl}-2$ de extratos citoplasmáticos de mucosa colônica de animais tratados com geraniol ou beta-ionona, isoladamente ou em associação, durante as etapas de iniciação e pós-iniciação de modelo de carcinogênese de cólon 
V DISCUSSÃO. 69

VI CONCLUSÕES 89

VII REFERÊNCIAS BIBLIOGRÁFICAS. 90

VIII ANEXOS OBRIGATÓRIOS 106 


\section{LISTA DE ILUSTRAÇÕES}

Figura 1. Diagrama representando as zonas de uma cripta no cólon.............. 20

Figura 2. Seqüência Adenoma-Adenocarcinoma de cólon.............................. 23

Figura 3. Esquema do metabolismo da DMH 29

Figura 4. Via resumida do mevalonato.................................................... 33

Figura 5. Estrutura química do monoterpeno geraniol................................... 37

Figura 6. Estrutura química do isoprenóide beta-ionona.............................. 39

Figura 7. Protocolo experimental....................................................... 46

Figura 8. Esquema representando a região do cólon do rato a ser analisada. 47

Figura 9. Esquema representando a divisão dos fragmentos do cólon............ 48

Figura 10. Evolução do peso de ratos Wistar normais ou tratados com água, óleo de milho, geraniol, beta-ionona ou associação durante 9 semanas consecutivas, em período compreendendo as etapas de iniciação e pósiniciação de modelo de carcinogênese de cólon.

Figura 11. Consumo de ração de ratos Wistar normais ou tratados com água, óleo de milho, geraniol, beta-ionona ou associação durante 9 semanas consecutivas, em periodo compreendendo as etapas de iniciação e pósiniciação de modelo de carcinogênese de cólon.

Figura 12. Focos de Criptas Aberrantes contendo 3,4 e 6 criptas, respectivamente, de cólon de rato Wistar submetido ao modelo de carcinogênese quando corado com Azul de Metileno.

Figura 13. Exemplos de "cometas" em células de mucosa colônica de ratos Wistar tratados com óleo de milho e submetidos ao modelo de carcinogênese de cólon

Figura 14. Expressão de $B c l-2$ avaliada por "westem blot" utilizando-se amostras de proteínas de extratos citiplasmáticos de mucosas colônicas de ratos Wistar sem tratamento ou tratados com OM, BI, GO ou GO+BI durante as etapas de iniciação e pós-iniciaçāo de modelo de carcinogênese de cólon Figura 15. Expressão normalizada dos valores obtidos por meio de "western blotting" para a proteina Bcl-2 entre nos diferentes grupos 


\section{LISTA DE TABELAS}

Tabela 1. Pesos corpóreos e consumo de ração de ratos Wistar normais ou tratados com $\mathrm{OM}, \mathrm{GO}, \mathrm{BI}$ ou $\mathrm{GO}+\mathrm{Bl}$ durante 9 semanas consecutivas, em periodo compreendendo as etapas de iniciação e pós-iniciação de modelo de carcinogênese de cólon

Tabela 2: Número total de FCAs e sua multiplicidade (FCAs < ou $\geq 4$ criptas) presentes em cólons de ratos Wistar tratados com OM, GO, BI ou GO + $\mathrm{BI}$ durante as etapas de iniciacão e pós-iniciação de modelo de carcinogênese de cólon

Tabela 3: Número total de FCAs e sua multiplicidade (FCAs $<$ ou $\geq 4$ criptas) presentes no cólon distal de ratos Wistar tratados com OM, GO, BI ou GO + BI durante as etapas de iniciação e pós-iniciaçāo de modelo de carcinogênese de cólon.

Tabela 4: Número total de FCAs e sua multiplicidade (FCAs < ou $\geq 4$ criptas) presentes no cólon proximal de ratos Wistar tratados com OM, GO, BI ou GO + Bl durante as etapas de iniciação e pós-iniciação de modelo de carcinogênese de cólon.

Tabela 5 - Concentração de Colesterol Plasmático Total de ratos Wistar sem tratamento ou tratados com OM, GO, BI ou GO+BI durantes as etapas de iniciação e pós-iniciação de modelo de carcinogênese de cólon

Tabela 6. Comprimento dos "cometas" de amostras de mucosas colônicas de ratos Wistar tratados com OM, GO, BI ou GO + BI durante as etapas de iniciação e pós-iniciação de modelo de carcinogênese de cólon e, também, das mucosas de ratos normais $(N)$, tratados ou não com peróxido de hidrogênio ( $\mathrm{PH}$ - Controle Positivo). 


\section{LISTA DE ABREVIAÇÕES}

AOM - azoximetano

$\mathrm{BI}$ - beta-ionona

DMH - dimetilhiidrazina

EROs - espécies reativas de oxigênio

FCA - focos de criptas aberrantes

GO - geraniol

$\mathrm{GO}+\mathrm{Bl}$ - geraniol + beta-ionona

HMG-CoA - 3-hidroxi-3-metilglutaril Coenzima A

INCA - Instituto Nacional do Câncer

OMS - Organização Mundial da Saúde 
Geraniol, mas não beta-ionona ou associação desses isoprenóides, possui atividade quimiopreventiva em ratos submetidos a modelo de carcinogénese de cólon.

\section{Resumo}

VIEIRA, A. Geraniol, mas não beta-ionona ou associação desses isoprenóides, possui atividade quimiopreventiva em ratos submetidos a modelo de carcinogênese de cólon. 2007. 116 f. Dissertação (Mestrado) Faculdade de Ciências Farmacêuticas, Universidade de São Paulo, São Paulo, 2007.

Diversos estudos epidemiológicos têm demonstrado que isoprenóides presentes em frutas e hortaliças possuem ação protetora contra o desenvolvimento de câncer. Objetivou-se, no presente trabalho, avaliar as eventuais atividades quimiopreventivas dos isoprenóides geraniol (GO) e beta-ionona (BI) quando administrados a ratos Wistar, isoladamente ou em associação, continuamente durante as etapas de iniciação e pós-iniciação de modelo de carcinogênese de cólon induzida por dimetilhidrazina. A atividade quimiopreventiva desses compostos foi observada microscopicamente por meio da análise de Focos de Criptas Aberrantes (FCAs) em cólons corados com azul de metileno $(0,02 \%)$. Verificou-se que, em comparação ao grupo controle apenas os ratos tratados com GO, mas não com BI, apresentaram redução $(p \leq 0,05)$ do número de lesões pré-neoplásicas (FCAs), no cólon distal, tanto em relação ao número de focos totais quanto aqueles com número maior ou igual do que quatro criptas. Por outro lado, somente tratamento com $\mathrm{BI}$ foi capaz de reduzir a concentração de colesterol plasmático total. Posteriormente, raspagem da mucosa colônica foi utilizada para a avaliação de danos no DNA pelo método do "Cometa". Em comparação ao grupo controle, tratamentos com GO, BI e GO+BI reduziram $(p \leq 0,05)$ o comprimento dos cometas indicando, dessa forma, diminuição de danos no DNA. Avaliou-se, ainda, a expressão de $B c l-2$, em nível de 
proteína, em mucosas colônicas dos animais dos diferentes grupos pele

Western Blot. Foi possivel notar uma redução nos valores da expressão pelos tratamentos com GO $(p \leq 0,05)$. Embora somente o tratamento com $\mathrm{GO}$ tenha inibido a formação de FCAs, tratamentos com $\mathrm{BI}$ e GO+BI podem ter apresentado efeitos protetores por inibirem os danos do DNA que não foram suficiente para a inibição da formação e crescimento de lesões pré-neoplásicas.

Palavras-chave: quimioprevenção, carcinogênese de cólon, geraniol, beta-ionona 


\begin{abstract}
VIEIRA, A. Geraniol, but not beta-ionone or association this isoprenoids, has chemopreventive activity in rats submitted to model of colon carcinogenesis. 2007. 116 f. Master's degree dissertation - Faculty of Pharmaceutical Sciences, University of Sao Paulo, Sao Paulo, 2007.

Several epidemiologic studies have shown consistently that isoprenoids presents in fruits and vegetables have a protective action against cancer. The objective of this study was to evaluate the chemopreventive effects of isoprenoids geraniol (GO) and beta-ionone $(\mathrm{Bl})$ during the initiation and pós-initiation phases of in rats submitted to model of chemical colon carcinogenesis induced by dimethylhydrazine (DMH). Aberrant Crypt Focus (ACFs) were detected using a light microscope in colons stained with $0,02 \%$ methylene blue. Treatment with GO significantly suppressed the total number of ACF and ACFs $\geq 4$ crypts per colon compared with the control group corn oil $(p \leq 0,05)$, mainly in the distal colon. In other hand, only treatment with $\mathrm{BI}$ reduced total plasma cholesterol levels compared with the control group $(p \leq 0,05)$. Subsequently colonic mucosa scraping was used for asses DNA damage through comet assay and expressed as comet length. DNA damage was inhibited in our study by all treatments $(p \leq 0,05)$. Analysis of $B c l-2$ protein from colonic mucosa scraping by Western Blot showed that treatment with $\mathrm{GO}$ reduced the values of expression de $B c /-2 \quad(p \leq 0,05)$. Although the results of this study suggest that treatment with $\mathrm{GO}$ has chemopreventive effects, treatments with $\mathrm{BI}$ and $\mathrm{GO}+\mathrm{BI}$ has initial protective action that maybe wasn't sufficient to reduce formation ACF.
\end{abstract}

Key-words: chemoprevention, colon carcinogenesis, geraniol, beta-ionone. 


\section{Introdução}

O câncer é uma das principais causas de morte em todo o mundo. De um total de 58 milhões de óbitos ocorridos em 2005, neoplasias malignas foram responsáveis por 7,6 milhões (13\%) deles. Segundo estimativas da Organização Mundial de Saúde (OMS, 2007) o câncer será responsável por 9 milhões de mortes em 2015 e 11,4 milhões em 2030.

Atualmente, mais de 11 milhões de indivíduos são diagnosticados com câncer a cada ano. Entretanto, estima-se que até 2020 esse número aumentará para 16 milhões de casos novos (OMS, 2007). Os principais tipos de cânceres que levam à mortalidade no mundo são: pulmão, estômago, fígado, cólon e mama.

Acompanhando a tendência mundial, o câncer é responsável por $13 \%$ dos óbitos no Brasil e é considerado um problema de saúde pública (KLIGERMAN, 2002). Assim, em 2006, foram constatados para o Brasil 234.570 casos novos para o sexo masculino e 237.480 para o sexo feminino. O câncer de pele não melanoma (116 mil casos novos) foi o mais prevalente na população brasileira, seguido pelo câncer de mama feminino (49 mil), próstata (47 mil), traquéia, brônquios e pulmão (27 mil), cólon e reto (25 mil), estômago (23 mil) e colo do útero (19 mil).

Em 2006, as neoplasias mais prevalentes para o sexo masculino, foram as de pele não melanoma (55 mil novos casos), próstata ( 47 mil), traquéia, brônquio e pulmão (18 mil), estômago (15 mil), cólon e reto (11 mil). Para o sexo feminino, destacaram-se as de pele não melanoma (61 mil casos novos), mama (49 mil), colo do útero (19 mil), cólon e reto (14 mil) e traquéia, brônquio e pulmão (nove mil) (INCÁ, Żồí, 
Geraniol, mas não beta-ionona ou associação desses isoprenóides, possui atividade quimiopreventiva em ratos submetidos a modelo de carcinogênese de cólon.

Dentre os cânceres mais comuns, o de cólon e reto soma a cada ano cerca de 943 mil casos novos em todo o mundo. É o segundo mais prevalente (após o câncer de mama), com uma estimativa de 2,4 milhões de indivíduos diagnosticados nos últimos cinco anos. A incidência de câncer de cólon e reto é mais elevada na América do Norte, Europa, Austrália, Nova Zelândia e na região sul da América do Sul. As menores taxas de incidência são encontradas na África e na Ásia; entretanto, as mesmas vêm aumentando nestas populações. Nos países desenvolvidos a incidência desse tipo de câncer é maior do que naqueles em desenvolvimento (INCA, 2006).

As estimativas de incidência de câncer no Brasil para 2006, publicadas pelo Instituto Nacional do Câncer (INCA), apontaram o câncer de cólon e reto como o $5^{\circ}$ tumor maligno mais freqüente em homens (com 11.390 novos casos) e o $4^{\circ} \mathrm{em}$ mulheres (13.970 novos casos). A maior incidência de casos ocorreu na faixa etária entre 50 e 70 anos, mas as possibilidades de desenvolvimento já aumentam a partir dos 40 anos (INCA, 2006).

Os principais fatores de risco são: idade acima de 50 anos; história familiar de câncer de cólon e reto; história pessoal pregressa de câncer de ovário, endométrio ou mama; dieta com conteúdo elevado de gordura, carne e teor reduzido de cálcio; obesidade e sedentarismo. Também são fatores de risco doenças inflamatórias do cólon como retocolite ulcerativa crônica; algumas condições hereditárias Polipose Adenomatosa Familiar e Câncer Colorretal Hereditário sem Polipose (INCA, 2006).

Neste contexto, a menos que se tomem medidas rigorosas de controle, o câncer converter-se-á na principal causa de mortes em muitos países no início deste século (OMS, 2007). 
Geraniol, mas não beta-ionona ou associação desses isoprenóides, possui atividade quimiopreventiva em ratos submetidos a modelo de carcinogênese de cólon.

Existem mais de 100 tipos e subtipos de neoplasias, que podem ser classificadas em benignas ou malignas. As primeiras apresentam uma proliferação celular localizada e circunscrita, exercendo pressão nos tecidos adjacentes, mas que não ultrapassam suas divisas. Em contraste, neoplasias malignas ou cânceres têm a capacidade de se multiplicar e invadir diferentes partes do organismo (HANAHAN; WEINBERG, 2000).

O desenvolvimento do câncer, ou seja, a carcinogênese consiste em um processo longo, ainda não bem elucidado, envolvendo múltiplas etapas na transformação das células normais em células neoplásicas (FARBER; SARMA, 1987; LOEB et al., 2003).

A perda do controle da proliferação e a aquisição de características associadas com a progressão tumoral são conseqüências de alterações que ocorrem no conteúdo genético das células normais. A célula alterada, por adquirir maior capacidade de proliferação em relação às células vizinhas, sofre uma expansão clonal, transmitindo geneticamente sua alteração a todas as células que, a partir dela, se originam. O câncer pode ser considerado uma doença genética complexa que resulta de alterações simultâneas em genes geralmente relacionados à proliferação, diferenciação, reparo do DNA e morte celular (FRIEDBERG, 2003; PARMIGIANI; CAMARGO, 2004).

O desenvolvimento de neoplasia é considerado um processo ativo induzido por uma série de agentes de natureza física, biológica ou química. Os carcinógenos químicos que não necessitam de ativação prévia são denominados de carcinógenos diretos, enquanto que os indiretos (ou pró-carcinógenos) são convertidos a carcinógenos definitivos após metabolização por enzimas de fase I (VENITT, 1994). 
Exemplos de carcinógenos diretos são as nitrosamidas (alquil nitrosouréia), o bis (cloro) metil éter e a mostarda nitrogenada. Já as aminas aromáticas do tipo 2acetilaminofluoreno e 2-naftilamina, hidrocarbonetos aromáticos policíclicos (como, por exemplo, o benzopireno), as aflatoxinas, o cloreto de vinila, nitrosamidas e nitrocompostos aromáticos, compostos heterocíclicos do tipo dos nitrofuranos e a dimetilhidrazina (DMH) constituem pró-carcinógenos (DIPPLE, 1995; GUSTIN; BRENNER, 2002).

A carcinogênese pode ser dividida em múltiplas etapas, que basicamente se classificam em: iniciação, promoção e progressão (PITOT, 2001; YOUNG; YANG; COLBURN, 2003).

A iniciação é definida como uma fase com mudanças permanentes e irreversíveis nas células (PITOT; DRAGAN, 1996), caracterizada por diversas modificaçōes moleculares, incluindo danos no DNA (FARBER; SARMA, 1987) e mutações em genes específicos, como genes supressores de tumor e oncogenes (POIRIER, 2004). Essas mutações específicas em regiōes com formação de adutos no DNA durante sua replicação ou durante o reparo de protooncogenes seriam responsáveis pelo processo de iniciação, e um ciclo de proliferação celular fixaria tais mutações. A partir desse momento a célula iniciada pode se transformar em maligna, se receber ou não estímulos promotores de malignidade (HEMMINKI, 1993, FORMAN et al., 2004).

A etapa subseqüente à iniciação é representada pela promoção que, por sua vez, apresenta longa duração (SING E GABY, 1991). Nessa etapa ocorre a expansão clonal seletiva das células iniciadas pela ação de um agente promotor formando, assim, lesões pré-neoplásicas (KLAUNIG et al., 2000; PITOT, 2001; 
YOUNG et al., 2003, FORMAN et al., 2004). Dessa forma, diferentemente da iniciação, a promoção é caracterizada pela sua reversibilidade que resulta da remoção do agente promotor (PITOT, 2001).

O último estágio, a progressão, é caracterizado por instabilidade cariotípica e metástase. Alterações na estrutura do genoma das células estão relacionadas, nesta etapa, com uma taxa de proliferação aumentada, com o caráter invasivo e alterações bioquímicas nas células (PITOT, DRAGAN, 1996; YOUNG et al., 2003).

Especificamente no caso de cânceres de cólon, cerca de 95\% deles originamse da superfície epitelial. As células epiteliais do cólon são particularmente mais vulneráveis às alterações genéticas devido à constante exposição a carcinógenos presentes na dieta e àqueles produzidos pela flora bacteriana (BUTLER et al., 1999).

O epitélio intestinal é um tecido que apresenta proliferação celular elevada, sendo sua homeostase regulada por um balanço entre a proliferação, a apoptose e a diferenciação celular. Aceita-se, atualmente, que os tipos celulares diferenciados do intestino são derivados de uma célula progenitora pluripotente comum, a stem cell ou célula-tronco, localizada na base da cripta do cólon. No intestino grosso, a proliferação celular ocorre na região basal (zona proliferativa) das criptas intestinais onde a taxa de apoptose é muito pequena. Células-tronco pluripotentes dividem-se e, quando diferenciadas, migram em direção à superfície da mucosa. Nas regiōes superiores, o processo de divisão celular cessa, sendo que na superfície epitelial da cripta as células senescentes são perdidas por uma forma de morte celular programada, chamada de anoikis, em que a esfoliação precede a apoptose. Dessa forma, as células perdem sua propriedade de adesão o que, em contrapartida, induz a apoptose (RONCUCCl et al., 2000; JOHNSON, 2002; WONG; GIBSON, 2003). 
Geraniol, mas não beta-ionona ou associação desses isoprenóides, possui atividade quimiopreventiva em ratos submetidos a modelo de carcinogênese de cólon.

A capacidade da célula de sofrer apoptose é determinada pela sua posição (ou hierarquia) na cripta e de possiveis mudanças às quais essas células são submetidas no meio extracelular à medida que alcançam o topo da cripta (POTTEN et al., 1997). Figura 1.

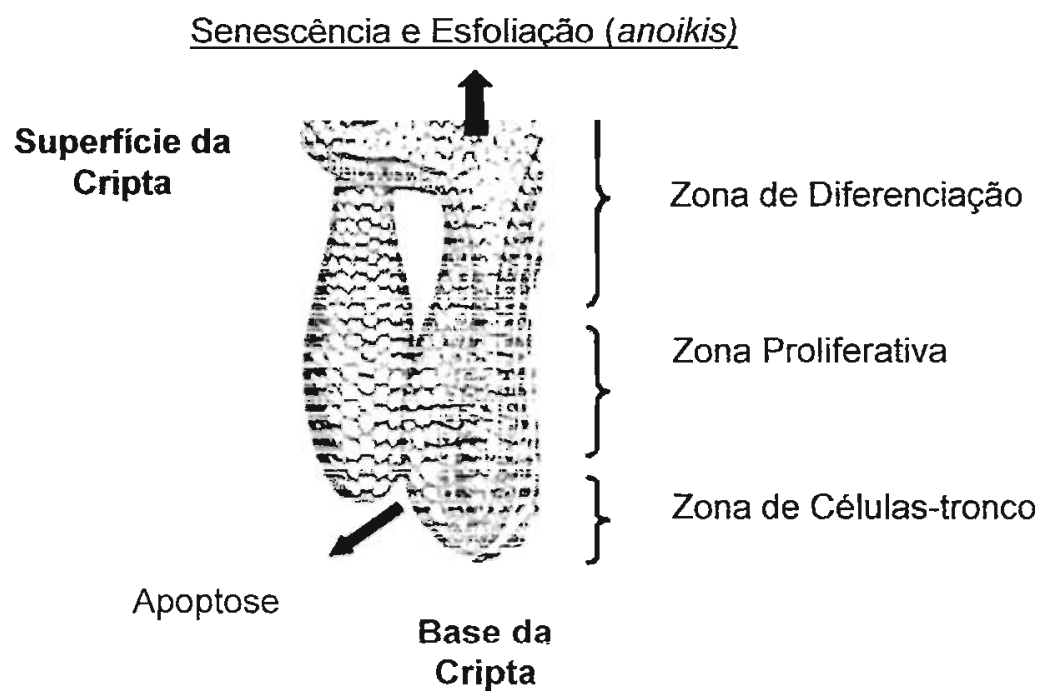

Figura 1. Diagrama representando as zonas de uma cripta no cólon (Johnson, 2002).

A zona proliferativa da cripta também é responsável pela ocorrência de apoptoses espontâneas que atuam como um mecanismo de controle da expansão da população de células-tronco nas criptas, embora tal mecanismo ocorra em uma proporção significativamente menor no cólon, em comparação ao intestino delgado (POTTEN et al., 1997; JOHNSON, 2002). Considerando-se que o cólon apresenta uma menor capacidade de remover sua população adicional de células-tronco, o maior número dessas células resultaria em um aumento da quantidade de criptas 

submetidos a modelo de carcinogênese de cólon.

susceptiveis ao desenvolvimento de mutações e, dessa forma, na expansão clonal das células iniciadas (POTTEN et al., 1997; WONG, GIBSON, 2003).

A apoptose é intensamente regulada por proteínas da familia Bcl-2. Essas podem exercer papel pró ou anti-apoptótico e participam de uma ampla variedade de cascatas de sinalizações. Interações entre proteínas dessa família com outras resultam na morte ou não da célula. Dessa forma, descreve-se que os membros da familia de proteínas $\mathrm{Bcl}-2$ são importantes reguladores da morte celular programada e a sua expressão estaria alterada em diversos tipos de neoplasias. O papel especifico de $\mathrm{BCl}-2$ seria o de inibir a apoptose. Logo um aumento de sua expressão significaria para a célula uma menor tendência em sofrer apoptose. Portanto, o acúmulo dessa proteína citoplasmática seria um indicativo de estado patológico (SHANMUGATHASAN; JOTHY, 2000).

Relatos de alterações de $\mathrm{Bcl}-2$ na carcinogênese de cólon confirmam o acima descrito. Essa proteína é altamente expressa na base da cripta colônica indicando que pode estar envolvida no principal mecanismo de homeostase nessas células. Essa hipótese é suportada por estudos em camundongos "knockout" para $\mathrm{BCl}-2$, onde a incidência de apoptoses espontâneas e induzidas é dramaticamente aumentada na região das células-tronco das criptas colônicas (RENEHAN et al., 2001). Esse gene tarnbém está mais expresso em epitélio não displásico adjacente a lesões displásicas, o que indica que expressão de $\mathrm{Bcl}-2$ já está elevada antes mesmo do desenvolvimento da displasia morfológica, ou seja, em fases iniciais da carcinogênese de cólon (RUPNARAIN et al., 2004).

Assim, o cólon é uma das sedes mais freqüente de neoplasias primárias no organismo, sendo que o evento mais precoce na carcinogênese de cólon envolve o 
Geraniol, mas não beta-ionona ou associação desses isoprenóides, possui atividade quimiopreventiva em ratos submetidos a modelo de carcinogénese de cólon.

desequilibrio da homeostase do epitélio colônico (POTTEN et al., 1997; WONG, GIBSON, 2003). Dessa maneira, a alteração do padrão proliferativo de células epiteliais nas criptas e a perda do controle de morte celular programada estão presentes nas fases iniciais na formação de neoplasias colônicas (RONCUCCl et al., 2000).

Dados clínicos e histopatológicos confirmam o fato de que neoplasias colônicas malignas (carcinomas) originam-se de neoplasias benignas (adenomas) preexistentes (FEARON, VOGELSTEIN, 1990). Dessa forma, uma associação entre carcinomas e pólipos de cólon foi descrita baseada em observações epidemiológicas e patológicas, sendo conhecida hoje como a seqüência ADENOMA - CARCINOMA (Figura 2). De uma forma geral, pode-se dizer que a carcinogênese de cólon é um processo que envolve múltiplas etapas, levando a mucosa normal ao desenvolvimento do carcinoma, através de uma série de alterações genéticas (FEARON, VOGELSTEIN, 1990). 
Geraniol, mas não beta-ionona ou associação desses isoprenóides, possui atividade quimiopreventiva em ratos submetidos a modelo de carcinogênese de cólon.
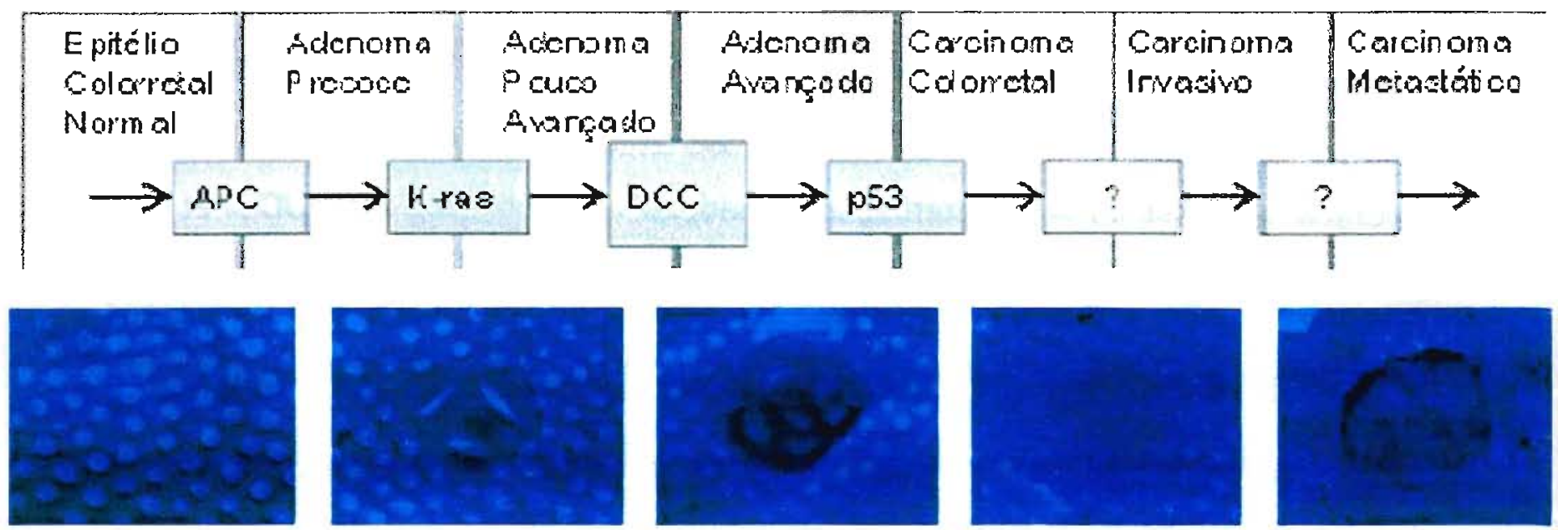

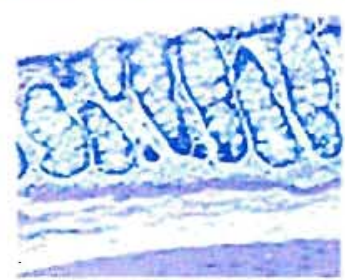

Epitélio Normal

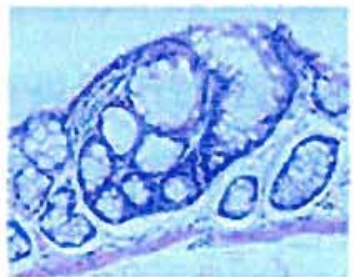

FCA nãodisplásico

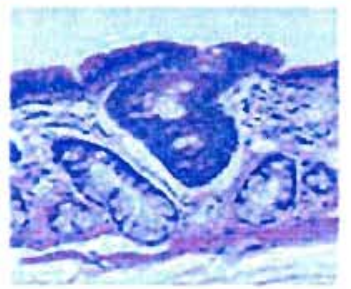

FCA displásico $(<$ grau $)$

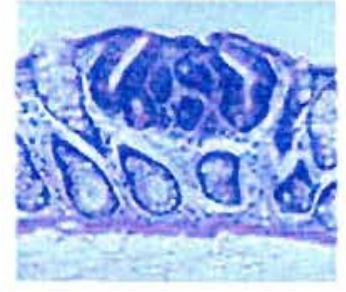

FCA displásico (> grau)

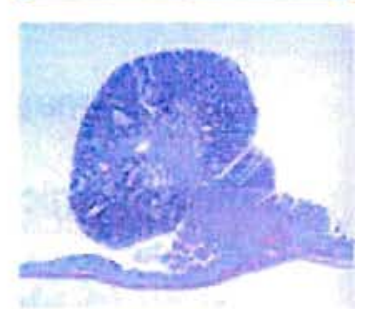

Adenocarcinoma

Figura 2. Seqüência Adenoma-Adenocarcinoma de cólon (Gil, Rowland, 2002).

Primeiramente. a neoplasia de cólon parece originar-se como resultado da ativação mutacional de oncogenes juntamente com uma inativação mutacional de genes supressores de tumor. Posteriormente, um acúmulo de mutações genéticas em quatro ou cinco genes adicionais é requerido para a formação de um tumor maligno. Assim, Fearon e Vogelstein em 1990, a partir de observações em neoplasias esporádicas, postularam a provável seqüência de mutações genéticas mais freqüentemente identificadas na carcinogênese de cólon, bem como correlacionaram a ocorrência de tais mutações com lesões amplamentes aceitas como precursoras do câncer de cólon. 
Geraniol, mas não beta-ionona ou associaçăo desses isoprenóides, possui atividade quimiopreventiva em ratos submetidos a modelo de carcinogénese de cólon.

Nos anos 1980, Ranjana Bird, examinando a superfície da mucosa de cólons corados com azul de metileno de ratos tratados com o carcinógeno azoximetano (AOM) observou, sob um microscópio de luz, a presença de criptas que apresentavam maior tamanho e espessura, e que se coravam mais intensamente quando comparadas às criptas normais (BIRD, 1987). Essas criptas foram denominadas de aberrantes e consideradas prováveis precursoras do câncer de cólon experimental. Essas lesões tendiam a se agrupar em aglomerados chamados Focos de Criptas Aberrantes (FCAs), os quais aumentavam de tamanho com o tempo. Esses focos foram posteriormente descritos na mucosa do cólon de seres humanos (PRETLOW, 1991) e amplamente associados com o risco de desenvolvimento de câncer de cólon nos mesmos.

FCAs são lesões precursoras do câncer de cólon. Sua indução, especificidade, crescimento, alterações morfológicas e genéticas confirmam a noção de que são lesões pré-neoplásicas. Características chaves sustentam essa hipótese: vários FCAs exibem displasia (uma característica citológica pré-cancerosa em muitos órgãos) e exibem atipia proliferativa e genética em comum com àquela encontrada no câncer. Com isso, nota-se a importância desse biomarcador para compreensão da patogênese do câncer de cólon (MECLELLAN; MEDLINE; BIRD, 1991; BIRD; GOOD, 2000).

Por outro lado, somente um determinado número de lesões pré-neoplásicas desenvolve-se em adenomas, alguns dos quais desenvolvem-se, subseqüentemente, em adenocarcinomas. Esse fato inclui o conceito de que lesões precursoras regridem, remodelam ou apenas deixam de progredir (BIRD, 1995). Isto explica a maior incidência de FCAs quando comparada à de neoplasias 
Geraniol, mas não beta-ionona ou associação desses isoprenóides, possui atividade quimiopreventiva em ratos submetidos a modelo de carcinogênese de cólon.

propriamente ditas. Além disso, há indícios de que FCAs podem se originar de eventos de iniciação independentes e, quando examinados histologicamente, mostram características distintas, variando em hiperplasia a diferentes graus de displasia (CHENG; LAI, 2003).

Assim, dois tipos de FCAs podem ser reconhecidos: hiperplásicos ou displásicos. FCA hiperplásico é a variedade mais comum, geralmente apresenta mutação em K-ras, mas evidências sugerem pequena probabilidade de que progrida para lesões neoplásicas. Menos comum, porém mais importante, é o FCA displásico, uma provável lesão precursora que está fortemente relacionada à progressão neoplásica. Os dois tipos podem apresentar aumento de proliferação celular, mas somente FCAs displásicos possuem mutações no gene APC (Polipose Adenomatosa Coli) e podem ser considerados precursores de adenomas (RENEHAN et al., 2001). Atualmente, novos tipos de lesões têm sido descritas em modelo de FCAs induzidos por AOM. Yamada et al identificaram criptas com acúmulo de beta-catenina por métodos de imunoistoquímica e Caderni et al. observaram focos depletados de mucina em cólons não seccionados corados com azul de alciano (CADERNI et al, 2003; VOLATE et al., 2005,). Mais recentemente ainda, foram identificados por Paulsen et al. os chamados "FCAs planos", caracterizados por abertura luminal comprimida, coloração azul brilhante e por criptas não elevadas em relação à mucosa ao redor. Essas lesões podiam ser vistas em cólons não seccionados corados com azul de metileno e analisados por transluminação em microscópio de luz invertida. Todas essas lesões citadas apresentam redução na produção de mucina, acredita-se que sejam lesões prémalignas antes que pré-neoplásicas (ou seja, lesões mais tardias e mais 
Geraniol, mas não beta-ionona ou associação desses isoprenóides, possui atividade quimiopreventiva em ratos submetidos a modelo de carcinogénese de cólon.

avançadas), que estejam relacionadas com displasia e com o controle alterado da via de sinalização de beta-catenina (Via Wnt-Tcf4), o que não é observado em parte dos FCAs clássicos (já caracterizados por hiperplasia, expressão normal de betacatenina e crescimento lento das criptas, o que não estaria diretamente relacionado ao desenvolvimento de neoplasias malignas). Na maioria dos cânceres de cólon esporádicos (assim como no caso da síndrome de Polipose Adenomatosa Familial) uma conseqüência da mutação do gene APC é o acúmulo de beta catenina. Com isso, ela pode translocar-se para o núcleo com conseqüente ativação da transcrição de oncogenes como o c-myc, ciclina D1 e c-jun (CORPET; PIERRE, 2005).

Em humanos, FCAs foram descritos e parcialmente caracterizados por Pretlow em 1991 e posteriormente em 1994 foi detectada atividade enzimática e proliferação celular alterada em suas criptas. FCAs em cólons humanos assemelham-se àqueles observados em roedores tratados com carcinógenos e também são localizados mais freqüentemente no cólon distal do que no proximal, apresentam epitélio hiperproliferativo com expansão da zona proliferativa para regiōes superiores da cripta, seu tamanho pode aumentar com a idade e em pacientes com adenomas e é evidente que a atipia nuclear observada em alguns FCAs é similar àquelas vistas em criptas de adenocarcinomas de cólon de roedores (CHENG, LAl; 2003). Além disso FCAs hiperplásicos de humanos tarnbém apresentam mutações em K-Ras e mutações em APC são restritas aos FCAs displásicos (RENEHAN et al., 2001).

Porém, não podemos excluir o fato de que alguns FCAs clássicos possam representar estágios mais precoces dos FCAS displásicos, ou que alguns dos grandes FCAs clássicos (ou seja, aqueles de maior multiplicidade) possam adquirir 
Geraniol, mas não beta-ionona ou associação desses isoprenóides, possui atividade quimiopreventiva em ratos submetidos a modelo de carcinogênese de cólon.

mutações adicionais transformando-se em lesões com displasia grave e ativação aberrante da via Wnt. Isso pode ocorrer levando-se em conta que múltiplas doses de carcinógeno são administradas em modelos experimentais e também devido às mudanças epigenéticas que podem ocorrer na carcinogênese (PAULSEN et al., 2005).

Dessa maneira, compostos naturais que inibem o desenvolvimento de FCAs estão sendo testados para prevenir o câncer de cólon experimental. Por isso a análise de Focos de Criptas Aberrantes vem sendo largamente utilizada como biomarcador para avaliar agentes quimiopreventivos da carcinogênese de cólon em ratos (BAZO et al., 2002). As mudanças celulares e moleculares que ocorrem no interior dessas lesões podem fornecer importantes indícios a respeito da seqüência dos principais eventos em lesões mais avançadas (BIRD et al., 1997).

Visto que o padrão do desenvolvimento de neoplasias de cólon em ratos é semelhante ao observado em humanos (PRETLOW, 1991), modelos experimentais de carcinogênese de cólon vêm sendo considerados dentre os melhores para o estudo de neoplasias in vivo. Banerjee e Quirke (1998) detalharam os principais modelos destacando aqueles que utilizavam indução por agentes químicos em roedores. Frequentemente são usados carcinógenos químicos incluindo a dimetilhidrazina (DMH), azoximetano (AOM), metoximetano (MAM) e $N$-metil- $N$-nitroN-nitrosoguanidina (MNNG). A maioria desses compostos age por meio da metilação de nucleosídeos do DNA resultando em mutações críticas no material genético (GUSTIN; BRENNER, 2002).

DMH é um potente carcinógeno completo de cólon que é muito utilizado em estudos de efeitos da dieta em diferentes etapas da carcinogênese. Tratamentos 
com substâncias presentes na alimentação podem ter início antes da exposição à DMH, durante a fase de iniciação, durante a fase de pós-iniciação/promoção ou ainda na fase de progressão. Agentes quimiopreventivos podem ser categorizados em dois principais grupos: aqueles que afetam a iniciação bloqueando ou reparando o efeito genotóxico do carcinógeno (agentes bloqueadores) e aqueles que afetam os eventos de pós-iniciação atuando na proliferação de células iniciadas ou modificando o ambiente ao redor delas (agentes supressores) (BIRD, 1995). Vale ressaltar, ainda, a importância da escolha do protocolo experimental, visto que o agente testado pode inibir, bem como promover, o desenvolvimento de câncer dependendo de qual fase da carcinogênese esteja ocorrendo sua intervenção. Ainda, pode haver uma interação do agente testado com o carcinógeno quando utilizados ao mesmo tempo em um protocolo de iniciação. E para identificar agentes que poderiam inibir, retardar ou regredir o desenvolvimento de câncer de cólon é importante um sistema que possa quantificar o número e crescimento de lesões préneoplásicas como a análise de FCAs (BIRD, 1995).

Além disso, DMH é um agente alquilante e tratamento com esse composto quimico induz adutos nas bases nitrogenadas do DNA pela doação de grupamentos metilas, mutações pontuais, micronúcleo, troca de cromátides-irmãs, apoptose (BLAKEY et al., 1985), além de um aumento na proliferação em células epiteliais colônicas, características comuns ao câncer de cólon humano (MA et al., 2002). DMH é altamente específica para o cólon. Neoplasias induzidas por esse composto são de origem epitelial com histologia, morfologia e anatornia similares às neoplasias humanas, o que torna esse modelo excelente para estudo. (MASKENS, 1976; NEWELL; HEDDLE, 2004). 
Geraniol, mas não beta-ionona ou associação desses isoprenóides, possui atividade quimiopreventiva em ratos submetidos a modelo de carcinogênese de cólon.

Esse carcinógeno é metabolicamente ativado em vários compostos que apresentam a capacidade de metilar o DNA. Primeiramente a DMH é oxidada no figado transformando-se em azometano e este é oxidado novamente a azoximetano (AOM). Posteriormente, por n-hidroxilação, AOM é convertido a metilazoximetanol que será conjugado com o ácido glicurônico e secretado pela bile. Ao atingir o intestino é hidrolisado por beta-glicuronidases produzidas pelas bactérias intestinais e, assim, é desconjugado novamente a metilazoximetanol. Este último é oxidado a metilazoxiformaldeído, transformando-se em metildiazônio que forma o íon carbônio, sendo que este último pode causar metilação do material genético das células epiteliais do cólon (Figura 3) (SOHN et al., 2001).

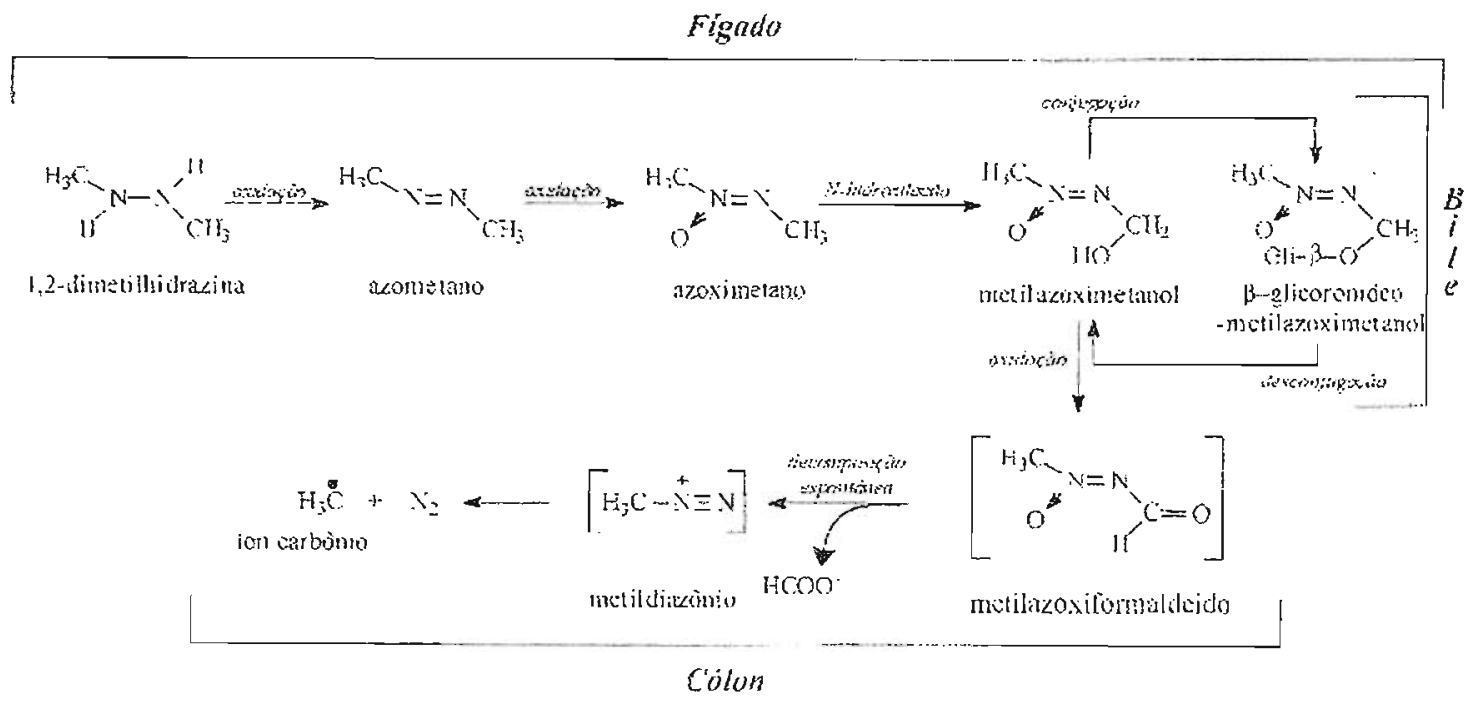

Figura 3: Esquema do metabolismo da DMH. Modificado de SOHN et al., 2001

Estudos têm mostrado que há um aumento em O6-metilguanina (O6-MeG) nas lesões formadas após a administração de $\mathrm{DMH}$ e este dano é encontrado 
primariamente no cólon distal. Se não reparado, essas lesões podem ser fixadas em mutações (COOPER et al, 1978).

É possivel um aumento das mutações no tratamento com múltiplas doses de DMH devido à saturação da via de reparo. A administração de DMH resulta na formação de adutos de O6-MeG, os quais são reparados (principalmente quando administrada em doses menores) pela enzima metilguanina metiltransferase (MGMT). Em elevadas doses, porém, a grande quantidade de adutos pode, eventualmente, saturar o sítio dessas enzimas levando a um aumento desproporcional nas mutações, aumentando, assim, a mutagenicidade do carcinógeno (ROGERS; PEGG, 1977).

Assim, esse modelo induz mudanças histológicas e moleculares na mucosa intestinal de roedores que replicam a seqüência adenoma-carcinoma vista em humanos (GUSTIN; BRENNER, 2002) onde a primeira, menor e mais precoce evidência histopatológica reconhecida em ambos os casos é a formação de Focos de Criptas Aberrantes. Esse modelo experimental também possibilita o estudo de agentes que possam interferir nesse processo.

Sabe-se que diversos compostos bioativos presentes em alimentos (CBAs) são capazes de modular distintos eventos biológicos relacionados à carcinogênese e à quimioprevenção de neoplasias, como a proliferação celular e a apoptose (MO; ELSON, 2004); contudo, seus mecanismos de ação são pouco compreendidos (AGGARWAL; SHISHODIA, 2006). Nesse contexto, a investigação desses mecanismos contribui não somente para a elucidação de aspectos fundamentais da carcinogênese e do comportamento biológico das neoplasias malignas, como também pode ter ainda um grande impacto em estratégias de prevenção (DE 
Geraniol, mas não beta-ionona ou associação desses isoprenóides, possui atividade quimiopreventiva em ratos submetidos a modelo de carcinogênese de cólon.

FLORA, FERGUSON, 2005). Assim, devido à complexidade dessa doença e às dificuldades de tratamento, diversos tipos de cânceres devem ser prevenidos, através de modificações no estilo de vida, como a adoção de bons hábitos alimentares (DOLL, 1992). Dessa forma, a quimioprevenção é considerada mais apropriada para diminuir o risco ou até mesmo evitar o desenvolvimento do câncer (THIERY-VUILLEMIN et al, 2005).

A quimioprevenção é definida como o uso de compostos naturais ou sintéticos que podem impedir, bloquear ou diminuir o risco da progressão carcinogênica para o câncer invasivo (THIERY-VUILLEMIN et al, 2005). Esse termo foi utilizado pela primeira vez por Michael Sporn, em 1976, como uma forma de se prevenir a doença por meio da administração de um ou mais compostos químicos durante as etapas iniciais pré-neoplásicas da carcinogênese, ou seja, na fase de iniciação ou promoção, e antes do estabelecimento da etapa de progressão (SPORN et al., 1976; LEE, PARK, 2003).

A quimioprevenção pode ser classificada de acordo com três estratégias:

1: Prevenção Primária do câncer em indivíduos saudáveis de alto risco (como por exemplo no caso de fumantes que possuem maior risco de desenvolverem câncer de pulmão ou de cabeça e pescoço);

2: Prevenção Secundária do câncer em indivíduos com lesões pré-cancerosas (como displasias por exemplo);

3: Prevenção Terciária, focada em pacientes que já tiveram câncer e para prevenir o desenvolvimento de tumor secundário (THIERY-VUILLEMIN et al, 2005; DE FLORA, FERGUSON, 2005). 
Geraniol, mas não beta-ionona ou associaçăo desses isoprenóides, possui atividade quimiopreventiva em ratos submetidos a modelo de carcinogénese de cólon.

Em 1981, uma revisão publicada por Doll e Peto forneceu estimativas quantitativas da proporção da variação da incidência do câncer em relação aos fatores ambientais incluindo a dieta (MATHERS, 2004). Assim, o comportamento alimentar contribui para com um terço da variação no risco de câncer, o que reforça a idéia de que a maioria dos cânceres da faixa etária de 65 anos pode ser potencialmente prevenida. Além disso, esses pesquisadores sugeriram que seria plausivel reduzir em $35 \%$ (com uma variação de 10 a $70 \%$ ) a mortalidade por câncer nos EUA por meio de modificações a serem realizadas na alimentação (MATHERS, 2004). Diversos estudos epidemiológicos ou com animais enfocaram a relação direta entre dieta e câncer de pulmão, cólon, mama, próstata, estômago, bexiga, entre outros (WARGOVICH et al., 2000; FORMAN et al., 2004), sendo que dieta contendo frutas, hortaliças e fibras apresentou efeito protetor (DOLL, 1990; VOLATE et al., 2005; VANAMALA et al., 2005)., que se deve principalmente à ação dos compostos bioativos presentes nesses alimentos (DAVIS; MILNER, 2004).

Além disso, aspectos da alimentação mencionados como possíveis causas de câncer foram: o consumo de alimentos em excesso (cânceres de útero e vesícula biliar em mulheres), as gorduras (cânceres de mama, cólon e reto) e carnes (cânceres de cólon e reto) (DOLL, 1990).

Vale ressaltar que a avaliação da atividade quimiopreventiva de certos compostos em modelos experimentais com animais é essencial para que se prossiga com ensaios clínicos. Portanto, a busca de mecanismos que elucidem a relação entre dieta e outros fatores de estilos de vida com o câncer é de fundamental importância para esclarecer aspectos dos vários estágios da 
Geraniol, mas não beta-ionona ou associação desses isoprenóides, possui atividade quimiopreventiva em ratos submetidos a modelo de carcinogênese de cólon.

carcinogênese e promover um grande impacto em estratégias de prevenção (FORMAN et al., 2004).

Dentre os inibidores da carcinogênese até agora identificados, pode-se citar alguns derivados do metabolismo do mevalonato em plantas, os assim denominados isoprenóides, em função de sua promissora ação relatada na quimioprevenção e quimioterapia do câncer (ELSON, YU, 1994; MORENO et al., 1995; ELSON et al., 1999; RAO et al., 2002; LIU et al., 2004).

A via do mevalonato é responsável pela formação do colesterol em mamíferos e de diversos isoprenóides no metabolismo secundário de plantas (MO; ELSON, 2004) (Figura 4).

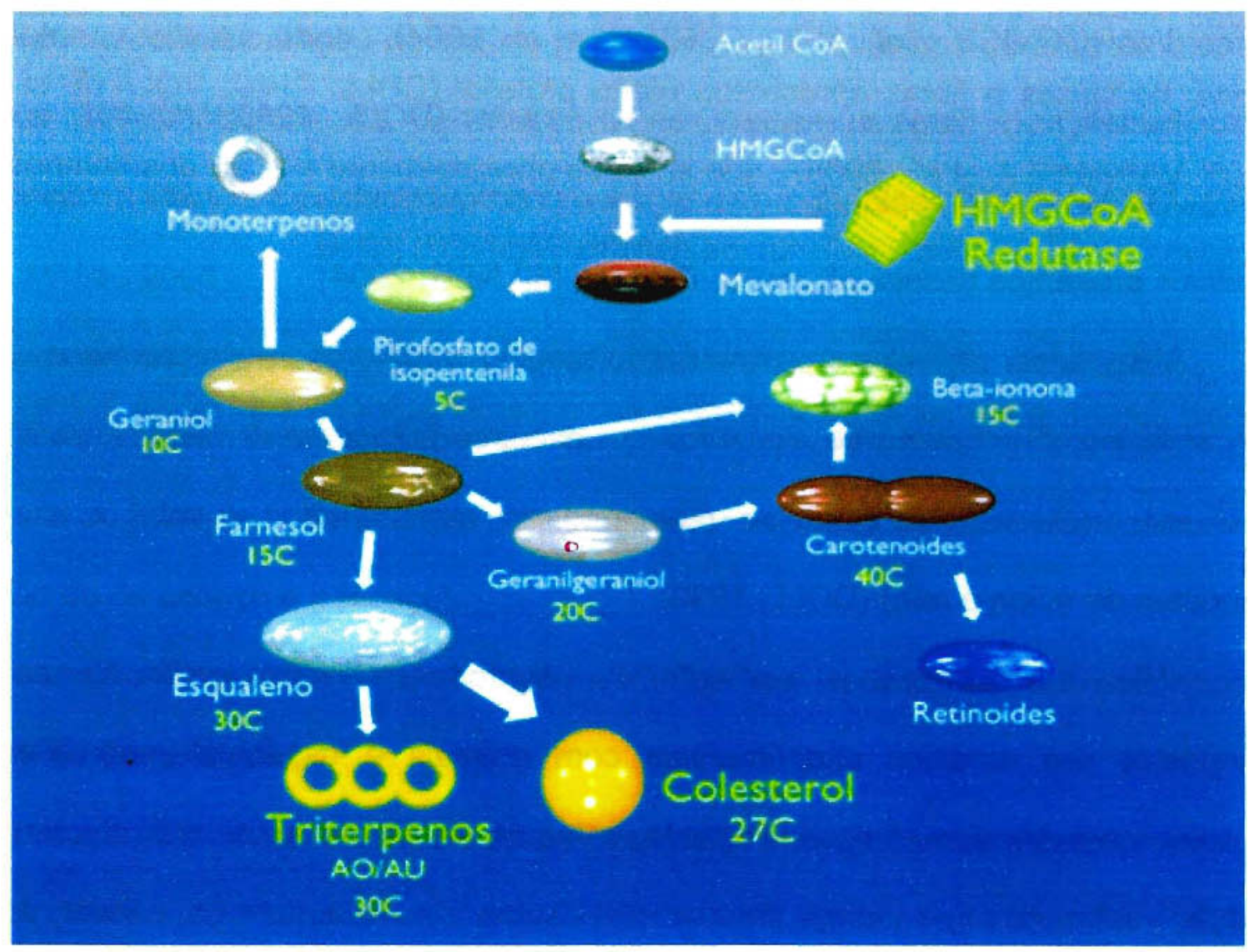

Figura 4: Via resumida do mevalonato (Adaptada de Crowell et al., 1991; Elson, 1995). 
O colesterol é um dos principais componentes da membrana plasmática e é essencial para a proliferação e divisão celular. Desempenha papel vital na manutenção da integridade celular, na regulação da fluidez da membrana e age como hormônios e ácidos biliares (BARKOVICH; LIAO, 2001; SUÁREZ et al, 2005).

Isoprenóides (ou terpenos) derivam seu nome do isopreno, uma molécula composta de cinco carbonos chamada também de unidade isoprênica (C5). A primeira etapa da via do mevalonato é a formação de acetil-CoA que se transforma em 3-hidroxi-3-metilglutaril-CoA e que a seguir é reduzida a mevalonato pela HMGCoA-redutase. Posteriormente, o mevalonato é convertido em pirofosfato de isopentenila (C5) e adições sucessivas de unidades isoprênicas vão formando os diversos isoprenóides. Assim, terpenos são classificados baseando-se no número de unidades isoprênicas presentes em sua estrutura. Monoterpenos possuem dez carbonos (C10), sesquiterpenos possuem quinze carbonos (C15), diterpenos possuem vinte carbonos (C20), sesterterpenos possuem vinte e cinco (C25), triterpenos possuem trinta carbonos (C30) e tetraterpenos possuem quarenta carbonos (C40) (BARKOVICH; LIAO, 2001).

A etapa crítica dessa via consiste justamente na formação do mevalonato que é catalisada por uma das enzimas mais reguladas da natureza: 3-hidroxi-3metilglutaril-Coenzima-A-redutase (HMGCoA-redutase) (MO, ELSON, 2004). Em animais de experimentação foi verificado que HMGCoA-redutase é modulada por um controle multivalente, sendo reprimida por produtos esteróis como o colesterol em niveis transcricionais, e não esteróis, como os isoprenóides derivados do metabolismo do mevalonato, em níveis pós-transcricionais (GOLDSTEIN; BROWN, 1990). 
Geraniol, mas não beta-ionona ou associação desses isoprenóides, possui atividade quimiopreventiva em ratos submetidos a modelo de carcinogênese de cólon.

Na carcinogênese essa enzima possui uma atividade elevada e desregulada e, ainda, apresenta perda do mecanismo de retro-regulação inibitória do colesterol. Por outro lado, em lesões pré-neoplásicas e neoplásicas, ela mantém maior sensibilidade à regulação mediada pelos isoprenóides. Em consequência de tal inibição, limitar-se-ia a disponibilidade de intermediários derivados da via do mevalonato, necessários à modificação pós-traducional de proteinas relacionadas com a proliferação celular (ELSON, 1995; ELSON et al., 1999; TATMAN; MO, 2002; MO; ELSON, 2004). Esta poderia ser uma possível explicação para a atividade inibitória do desenvolvimento de neoplasias, constatada após administração de isoprenóides (ELSON, 1995; MORENO et al., 1995; ELSON et al., 1999).

Frutas, hortaliças e grãos de cereais constituem fontes ricas em derivados do metabolismo do mevalonato. Mais especificamente encontra-se o monoterpeno $d$ limoneno em óleos essenciais da laranja e outras frutas cítricas; álcool perililico na cereja e hortelã; carvona na hortelã, farnesol na erva cidreira (RAO et al., 2002) e no morango (TATMAN; MO, 2002); a beta-ionona em uvas e aromatizantes de vinhos (ESPÍNDOLA et al., 2005) e o geraniol no óleo de erva cidreira (RAO et al., 2002), limão (LOTA et al., 2002) e no vinho tinto.

Isoprenóides cíclicos como o beta-caroteno (MORENO et al., 1995), mentol (CLEGG et al., 1982), beta-ionona (ELSON; YU 1994) e acíclicos como citral (FITCH et al., 1989), licopeno (FUHRMAN et al., 1997) e o geraniol (FITCH et al., 1989) inibem a atividade da enzima HMGCoA redutase por meio de mecanismos póstranscricionais (PEFFLEY, 2003). Tem sido descrito que os isoprenóides cíclicos (CLEGG et al., 1982) e acíclicos "mistos" (PARKER et al., 1993) estimulam a 
degradação da enzima por meio da elevação de farnesol celular, ou ainda, atuando como homólogos deste.

Descreveram-se in vivo e in vitro atividades quimiopreventivas por parte de diversos isoprenóides tais como: farnesol (WARGOVICH et al., 2000; BURKE et al., 1997;2002; RAO et al., 2002, ONG et al., 2005; VOZIYAN et al., 1995), limoneno (ELSON et al., 1988), álcool perilílico (REDDY et al., 1997), esqualeno (RAO et al., 1998), geranilgeraniol (ESPÍNDOLA et al., 2005; OHIZUMI et al., 1995), betacaroteno (MORENO et al., 1991), licopeno (TOLEDO et al., 2003), luteína (TOLEDO et al., 2003), beta-ionona (ESPÍNDOLA et al., 2005) e geraniol (ONG et al., 2005).

Assim, de forma geral, as ações anticarcinogênicas de isoprenóides têm sido relacionadas à inibição da proliferação celular e estímulo da apoptose, decorrentes da supressão da via do mevalonato em lesões pré-neoplásicas e neoplásicas (ELSON, 1995; HE et al., 1997; MO; ELSON, 1999; LIU et al., 2004), como por exemplo alguns isoprenóides (como o álcool perilílico) e inibidores de HMGCoAredutase (como a lovastatina) suprimindo a expressão de genes que codificam proteínas da familia Bcl-2 (AGARWAL et al., 1999; BURKE et al., 2002).

Em trabalhos anteriores de nosso grupo, observou-se atividade quimiopreventiva do $\mathrm{GO}$ e da $\mathrm{Bl}$ quando administrados durante a fase de iniciação e promoção da hepatocarcinogêse em ratos submetidos ao modelo do Hepatócito Resistente. A ação quimiopreventiva por parte do GO foi atribuida à inibição da proliferação celular e indução da apoptose (ONG et al., 2005), enquanto a atividade quimiopreventiva da $\mathrm{BI}$ foi atribuída à inibição da proliferação celular nas lesões pré-neoplásicas e nas áreas sem alterações morfológicas ao redor dessas lesões (ESPINDOLA et al., 2005). Contudo, apesar da existência de alguns 
Geraniol, mas não beta-ionona ou associaçāo desses isoprenóides, possui atividade quimiopreventiva em ratos submetidos a modelo de carcinogênese de cólon.

trabalhos na literatura demonstrando a atividade anti-neoplásica desses compostos in vitro, não há relatos sobre a ação dessas substâncias durante a fase de iriciação e pós-iniciação de carcinogênese de cólon in vivo.

O geraniol é um monoterpeno acíclico encontrado naturalmente em óleos de plantas aromáticas, como a erva cidreira, e vem apresentando atividades quimiopreventivas em diversos modelos de carcinogênese (CARNESECCHI et al., 2004) (Figura 5).

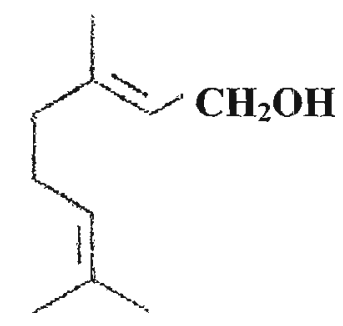

\section{Geraniol}

Figura 5. Estrutura química do monoterpeno geraniol (SHOFF et al., 1991).

Crowell (1999) discutiu a relação entre monoterpenos e câncer, ressaltando como atributos quimiopreventivos ideais desses agentes, uma ação anti-neoplásica eficaz em animais de experimentação, disponibilidade comercial, baixo custo, biodisponibilidade oral e reduziđa toxicidade, o que os tornaria candidatos potenciais para estudos de quimioprevenção contra o câncer em seres humanos.

Relatou-se uma redução na proliferação quando células P388 de leucemia e B16 de melanoma murínicos foram tratadas com geraniol e também quando camundongos transplantados com células P388 receberam ração contendo geraniol 
(SHOFF et al., 1991), esse monoterpeno acíclico considerado uma substância geralmente reconhecida como segura (GRAS), e aprovada para uso como aditivo alimentar (FEMA 2624, apud YU et al., 1995). Os resultados levaram os autores do estudo a sugerirem que monoterpenos e outros isoprenóides possam ser componentes importantes da ação anticarcinogênica de diversas frutas, hortaliças e cereais (SHOFF et al., 1991).

Esse isoprenóide causou inibição da proliferação celular da linhagem celular de adenocarcinoma humano Caco-2, com acúmulo de células na fase $S$ de transição do ciclo celular e, simultaneamente, inibição da síntese de DNA (CARNESECCHI et al., 2001).

Em outro estudo, foi investigada a eficácia anti-neoplásica do geraniol e do 5fluorouracil (utilizado na quimioterapia do câncer de cólon) em culturas de células (Caco-2 e SW 620) quando administrados isoladamente ou em associação. Ambas as substâncias também foram avaliadas em tumores humanos TC-118 transplantados em camundongos. O geraniol causou aumento da tolerância ao 5fluorouracil nas células cancerosas. Em camundongos, a administração combinada de 5 -fluorouracil e geraniol causou $53 \%$ de redução no volume do tumor, embora $26 \%$ desta redução foram observadas com o geraniol isoladamente. 5-fluorouracil isolado não mostrou qualquer efeito (CARNESECCHI et al., 2004).

Burke e col. (1997, 2002) avaliaram, in vivo, a ação anticarcinogênica do geraniol, do álcool perilílico e do farnesol no câncer de pâncreas. O geraniol e farnesol inibiram completamente o crescimento das neoplasias verificando-se, ainda, a regressão de algumas delas. Tanto o geraniol como o farnesol foram, nesse sentido, mais potentes do que o álcool perililico. Estes efeitos ocorreram sem o 
Geraniol, mas não beta-ionona ou associação desses isoprenóides, possui atividade quimiopreventiva em ratos submetidos a modelo de carcinogênese de cólon.

desenvolvimento de toxicidade significante nos animais e alteração na concentração plasmática de colesterol total. De acordo com os autores isto poderia indicar que o mecanismo de ação dessas substâncias possivelmente não se deu devido a uma inibição da atividade da enzima HMGCoA redutase, mas sim, a um estímulo da apoptose. Os autores sugeriram, ainda, que isoprenóides da dieta podem eventualmente representar potenciais agentes quimiopreventivos ou quimioterápicos, para a profilaxia e tratamento do câncer pancreático humano.

Uma promissora ação quimiopreventiva com inibição da proliferação celular, indução de apoptose e redução de danos no DNA pelo monoterpeno geraniol também foi observada quando administrado durante as fases iniciais de hepatocarcinogênese induzida em ratos Wistar (ONG et al., 2005).

Já a beta-ionona é um isoprenóide cíclico constituído por treze átomos de carbono e está presente em uvas e aromatizantes de vinho (Figura 6). É formado a partir da clivagem da molécula de beta-caroteno, resultando na formação de duas moléculas desse derivado isoprênico e uma molécula de dialdeído C14 (SIMKIN et al., 2004).

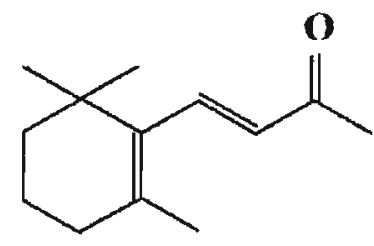

beta-ionona

Figura 6. Estrutura química do isoprenóide beta-ionona (Yu et al., 1994). 
Foi observado que o $\gamma$-tocotrienol e a beta-ionona suprimiram a proliferação de células B16 de camundongos (HE et al., 1997), bem como de células leucêmicas $\mathrm{HI}-60$, de adenocarcinomas de mama (MCF-7) e de cólon (Caco-2) humanos (MO; ELSON, 1999). Nesses casos, o tratamento com isoprenóides resultou em um bloqueio do ciclo celular em G1 e em estímulo da apoptose. Além disso, beta-ionona suprimiu a proliferação de fibroblastos (CCD-18Co) de cólon humano, quando presente em concentrações três vezes maiores comparada àquela requerida para células Caco-2. O isoprenóide induziu a apoptose e, concomitantemente, bloqueou células na fase G1 do ciclo celular, além de suprimir a atividade da enzima HMGCoA redutase (MO; ELSON, 1999).

Outro experimento mostrou que a beta-ionona inibiu a proliferação celular e induziu apoptose de linhagens de células SGC-7901 de adenocarcinoma gástrico (LIU, 2004).

Em modelo de hepatocarcinogênese a beta-ionona inibiu a incidência $e$ multiplicidade de nódulos hepáticos, bem como a área do fígado ocupada por lesões. Foi verificada redução de danos ao DNA em animais tratados com essa substância. Ocorreu, ainda, diminuição da proliferação celular e redução da concentração total de colesterol plasmático como uma medida indireta da atividade da enzima HMGCo-A redutase (ESPINDOLA et al., 2005).

Tratamento de fêmeas de Sprague-Dawley com beta-ionona por duas semanas antes da injeção do carcinógeno 7,12-dimetilbenzoantraceno durante 22 semanas demonstrou maior ação quimiopreventiva que geraniol e d-limoneno e resultou em inibição da incidência e multiplicidade de nódulos mamários (YU et al., 1995). 
Analisou-se os efeitos da beta-ionona e do geraniol na atividade da enzima HMG-CoA redutase em células MCF-7 de câncer de mama. Geraniol inibiu a atividade da HMG-CoA redutase nessas células, sendo que este efeito esteve estreitamente relacionado com a inibição da proliferação celular. Mevalonato exógeno, no entanto, não restaurou a proliferação das células inibidas pelo geraniol, indicando que essa relação não era causal. Já a beta-ionona não inibiu a atividade da HMG-CoA redutase, embora tenha inibido a proliferação celular de maneira dosedependente. Ainda que a depleção de mevalonato não tenha sido responsável pela inibição da proliferação celular por parte da beta-ionona e do geraniol, ambos compostos produziram efeitos na regulação do ciclo celular que são, contudo, similares àqueles já previamente relatados em células na ausência de mevalonato. Esses resultados indicam que a compreensão dos efeitos inibitórios no ciclo celular pelos isoprenóides requer mais investigações a respeito dos mecanismos independentes do mevalonato (DUNCAN et al., 2004).

Descreve-se na literatura que a atuação conjunta de isoprenóides pode favorecer a modulação de mecanismos relacionados à carcinogênese, de forma aditiva ou sinérgica. Trabalhos demonstraram que isoprenóides com estrutura cíclica, associada a isoprenóides com estrutura acíclica, poderiam estimular a degradação da enzima HMG-CoA redutase (CLEGG, et al., 1982; PARKER, et al., 1993).

He et al. (1997) demonstraram um efeito aditivo e potencialmente sinérgico dos isoprenóides beta-ionona (cíclico) e y-tocotrienol (acíclico) quando associados e administrados em cultura de células de melanoma, diminuindo o potencial de crescimento dessas células. Já a associação entre o carvacrol (cíclico) e a beta- 
ionona (cíclico) apresentou um efeito inferior ao previsto. Dessa forma, os autores sugeriram que uma associação entre isoprenóides somente cíclicos ou acíclicos não resulta em ação sinérgica. Mo e Elson (1999), ao avaliarem a associação entre betaionona e outros derivados isoprênicos em cultura de células, também não observaram um sinergismo ao associar isoprenóides somente cíclicos ou acíclicos, sugerindo uma possível atenuação da ação supressora de tumor daquele mais potente.

Assim, as atividades quimiopreventivas dos isoprenóides geraniol e betaionona foram demonstradas em alguns tipos de carcinogênese química. Dessa maneira, a administração dessas substâncias isoladas ou conjuntamente poderia representar uma contribuição importante para a quimioprevenção da carcinogênese de cólon in vivo. Convém ressaltar, ainda, que a literatura é escassa de informações nesse sentido. 
Geraniol, mas năo beta-ionona ou associação desses isoprenóides, possui atividade quimiopreventiva em ratos submetidos a modelo de carcinogênese de cólon.

\section{II- Objetivos:}

\section{Geral:}

Avaliar e comparar os eventuais efeitos quimiopreventivos do geraniol e da beta-ionona quando administrados isoladamente ou em associação a ratos Wistar continuamente durante as etapas de iniciação e pós-iniciação de modelo de carcinogênese de cólon.

\section{Específicos:}

Verificar possíveis modos de ação envolvidos com a ação das substâncias no modelo de carcinogênese de cólon avaliando:

II-1. A concentração plasmática de colesterol;

II-2. A presença de danos no DNA.

II-3. A expressão de $B c /-2$ em nível de proteína 
Geraniol, mas não beta-ionona ou associação desses isoprenóides, possui atividade quimiopreventiva em ratos submetidos a modelo de carcinogénese de cólon.

\section{III- Metodologia:}

\subsection{Animais}

Foram utilizados neste estudo 54 ratos machos albinos da linhagem Wistar, com pesos iniciais compreendidos entre 80 e $90 \mathrm{~g} \mathrm{e}$ obtidos da colônia do biotério da Faculdade de Ciências Farmacêuticas/Instituto de Química da Universidade de São Paulo. Estes permaneceram durante todo o experimento em sala desse mesmo biotério nas seguintes condições: temperatura de $22^{\circ} \mathrm{C} \pm 2^{\circ} \mathrm{C}$ e ciclo de iluminação claro-escuro de $12 \mathrm{~h}$ e receberam ad libitum durante todo o experimento, água filtrada e ração comercial peletizada comum para roedores de laboratório (Purina Nutrimentos Ltda., Brasil). O peso corpóreo e o consumo de ração foram avaliados diariamente.

Os ensaios biológicos foram realizados nas dependências do biotério da FCF/IQ-USP, após a devida aprovação do projeto pelo Comitê de Ética em Pesquisa em Animais de Experimentação (Protocolo CEEA n 75 ), em ambiente apropriado para condução de estudos de carcinogênese.

\subsection{Protocolo Experimental}

Após um período de aclimatação de 7 dias, com exceção de 6 ratos que constituiram um grupo sem tratamento, 48 animais foram submetidos a modelo de carcinogênese de cólon (Figura 7) (WARGOVICH et al., 2000; LIMA et al., 2005). O modelo consistiu na administração intraperitoneal de 4 doses de dimetilhidrazina 
(DMH 40mg/Kg de peso corpóreo p.c.), dissolvida em solução de EDTA (37 mg/100 $\mathrm{mL}$ de água destilada), distribuídas na segunda e terceira semana de experimento (2 doses para cada semana). Todos os animais receberam o tratamento com isoprenóides durante todo o experimento com início 2 semanas antes da administração da DMH (correspondendo às fases de pré-iniciação, iniciação e pósiniciação do modelo) e foram eutanasiados ao final da $9^{a}$ semana. (WARGOVICH et al., 2000; DIAS et al.,2006 ).

Os grupos experimentais, além do grupo que não foi submetido a nenhum tratamento, foram os seguintes:

Grupo óleo de milho (OM); grupo controle: este grupo foi composto por 12 animais tratados diariamente via entubação intragástrica com OM (Mazola $囚 ; 0,25$ mL/100 g p.c./dia);

Grupo Geraniol (GO): este grupo foi composto por 12 animais tratados diariamente via entubação intragástrica com GO (98\%; Sigma, EUA; 25 mg/100 g p.c./dia) dissolvido em OM (Mazola®; 0,25 mL/100 g p.c./dia);

Grupo Beta-ionona (BI): este grupo foi composto por 12 animais tratados diariamente via entubação intragástrica com BI (95\%; Sigma, EUA; 16 mg/100 g p.c./dia) dissolvida em OM (Mazolaß; 0,25 mL/100 g p.c./dia);

Grupo Geraniol + Beta-ionona (GO + BI): este grupo foi composto por 12 animais tratados diariamente via entubação intragástrica com GO (98\%; Sigma, EUA; 25 mg/100 g p.c./dia) e BI (95\%; Sigma, EUA; 16 mg/100 g p.c./dia) dissolvidos em OM (Mazola®; 0,25 mL/100 g p.c./dia). 
Geraniol, mas não beta-ionona ou associação desses isoprenóides, possui atividade quimiopreventiva em ratos submetidos a modelo de carcinogênese de cólon.

\section{Semanas}

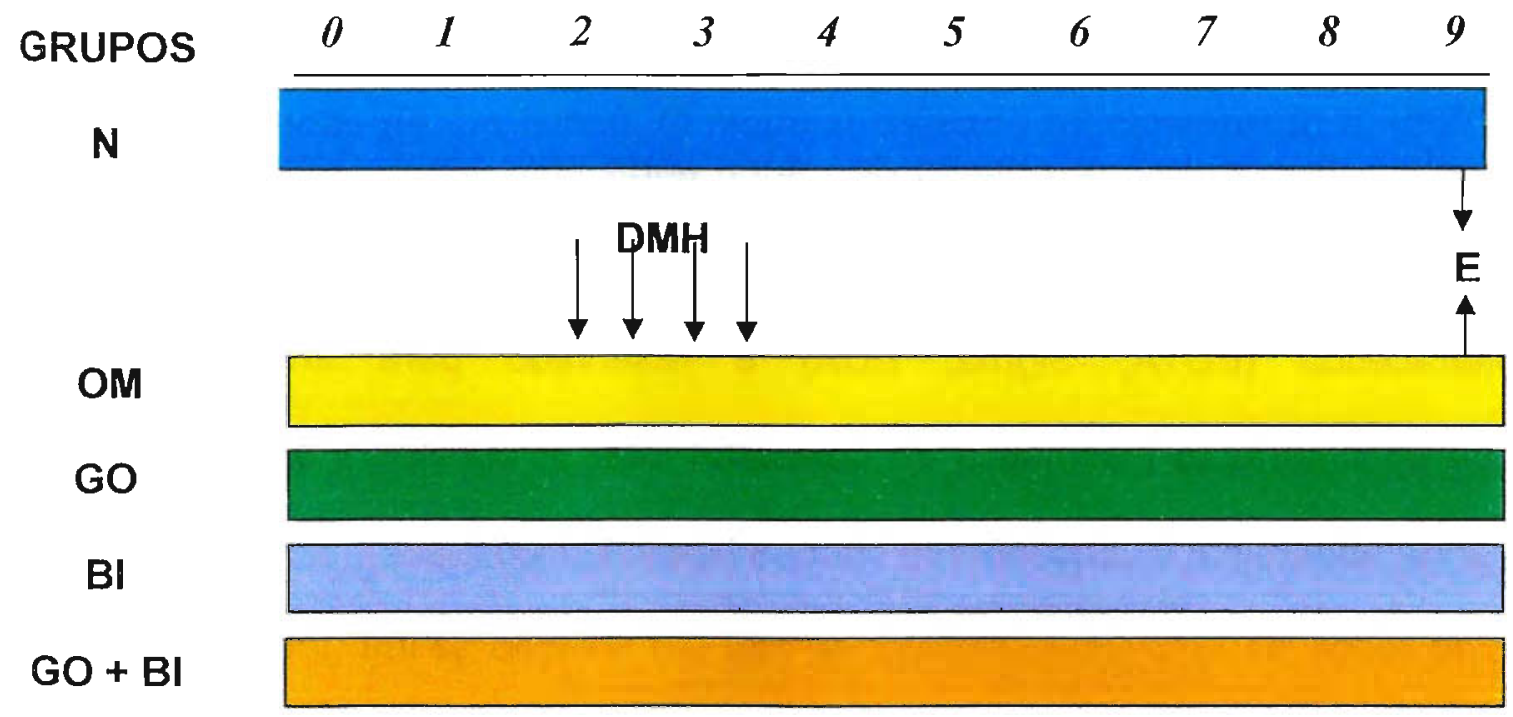

GRUPO SEM TRATAMENTO

GRUPO ÓLEO DE MILHO (OM) (CONTROLE) $(0,25 \mathrm{~mL} / 100 \mathrm{~g}$ p.c.)

GRUPO GERANIOL (GO) (25 mg/100 g p.c.)

GRUPO BETA-IONONA (BI) (16 mg/100 g p.c.)

GRUPO GERANIOL (25MG/100g p. c.) + BETA-IONONA (16 mg/100g p. c.)

DMH - 1,2- dimetilhidrazina (40mg/Kg p. c.)

\section{E - Eutanásia}

Figura 7 : Protocolo experimental. 
Geraniol, mas não beta-ionona ou associação desses isoprenóides, possui atividade quimiopreventiva em ratos submetidos a modelo de carcinogênese de cólon.

\subsection{Eutanásia dos animais e coleta do material}

Ao final da $9^{a}$ semana de experimento os animais foram anestesiados com éter e colocados em decúbito dorsal sobre uma prancha, realizando-se a laparotomia e, em seguida, a coleta de sangue por punção da artéria aorta abdominal. O sangue coletado foi mantido em tubos de polipropileno contendo $5 \mathrm{mg}$ de ácido etilenodiaminotetracético (EDTA, Sigma, EUA) e reservado para imediata determinação da concentração plasmática de colesterol total. A eutanásia ocorreu por secção da aorta abdominal e conseqüente choque hipovolêmico.

O cólon de todos os ratos foi removido, lavado em solução salina gelada a 0,9\% e delimitado seu comprimento (ZHENG et al, 1999). A seguir, foi aberto longitudinalmente, sendo que para a análise foi considerada a porção do cólon a partir de $1 \mathrm{~cm}$ do ceco até $1 \mathrm{~cm}$ do ânus, conforme Figura 8 (DAVIDSON et al., 2000).

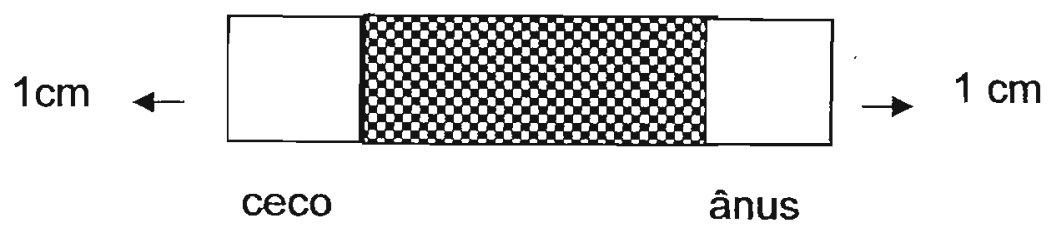

Região do cólon analisada

Figura 8. Esquema representando a região do cólon do rato analisada.

Toda porção do cólon foi dividida longitudinalmente em dois hemicólons. Um deles foi fixado em etanol a $70 \%$ e corado em $0,02 \%$ de azul de metileno (dissolvido em etanol a 70\%) durante 10 minutos (WALI et al, 2002). O cólon permaneceu em 
Geraniol, mas não beta-ionona ou associação desses isoprenóides, possui atividade quimiopreventiva em ratos submetidos a modelo de carcinogênese de cólon.

placa de vidro com a superficie da mucosa voltada para cima para a identificação e classificação, ao microscópio, de focos de criptas aberrantes (KOB-EK-JARSEN et al., 2005). Já a partir do outro hemicólon a mucosa foi coletada por raspagem com a utilização de um bisturi. $\mathrm{O}$ material coletado foi conservado a $-80^{\circ} \mathrm{C}$ para posterior análise da presença de danos no DNA e realização de técnicas de biologia molecular (DAVIDSON et al., 2000; WALI et al., 2002).
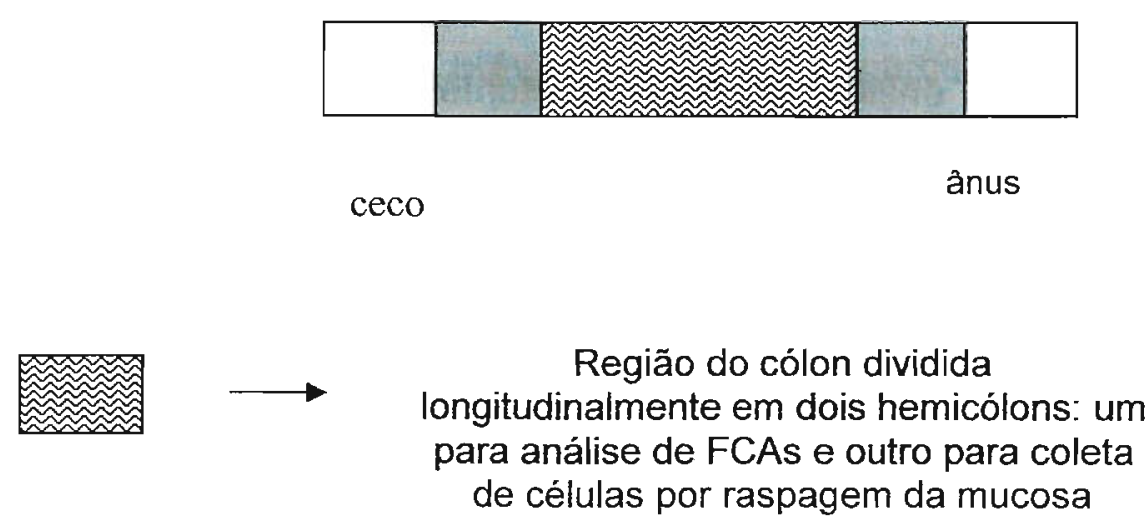

Figura 9. Esquema representando a divisão dos fragmentos do cólon.

\subsection{Pesquisa de Focos de Criptas Aberrantes (FCAs)}

Os cólons foram corados com azul de metileno a $0,02 \%$ por 10 minutos e em seguida analisados ao microscópio (Olympus; Japão) no aumento de 40X quanto à incidência de FCAs, número de criptas por foco (multiplicidade $=1,2,3$ ou $\geq 4$ criptas) e sua localização no cólon (região proximal ou distal) (WALI et al, 2002; WU et al., 2004). 
Os FCAs foram caracterizados por dilatações na abertura luminal, epitélio mais espesso e coloração mais intensa quando comparados às criptas vizinhas (BAZO et al, 2002).

\subsection{Determinação das Concentrações de Colesterol Plasmático Total}

Imediatamente após a colheita, o sangue foi adicionado a tubos de centrifugas contendo $500 \mu \mathrm{l}$ de EDTA $(10 \mu \mathrm{g} / \mu \mathrm{l})$, e centrifugado a $3500 \mathrm{~g}$, a $4^{\circ} \mathrm{C}$, por 10 min. Utilizou-se o "kit" enzimático-espectrofotométrico para a determinação de colesterol total (BioSystems, Espanha). Este se baseia em reações enzimáticas em que o colesterol presente na amostra (esterificado e não-esterificado) é oxidado, produzindo-se, em última instância, um complexo colorido quantificável espectrofotometricamente. O procedimento foi o indicado pelo fabricante: $10 \mu \mathrm{L}$ de amostra de plasma foram adicionados a $1 \mathrm{~mL}$ do reagente fornecido com o "kit". A solução foi homogeneizada e mantida a temperatura ambiente durante 10 min. Decorrido esse tempo, foi realizada leitura espectrofotométrica (U 3410, Hitachi, Japão) das amostras a $500 \mathrm{~nm}$. As absorbâncias das amostras de plasma foram comparadas à de uma amostra padrão de colesterol $(200 \mathrm{mg} / \mathrm{dL})$, que também foi fornecida juntamente com o "kit". De todos os valores de absorbância foi descontada a leitura do branco ( $1 \mathrm{~mL}$ de reagente, sem a adição de amostra ou padrão). Todas as determinações de colesterol plasmático total foram realizadas em triplicata. 


\subsection{Avaliação de Danos no DNA da Mucosa do Cólon:}

A avaliação de danos no DNA do cólon foi realizada em amostras contendo raspagem da mucosa colônica previamente armazenada a $-80^{\circ} \mathrm{C}$, utilizando-se o método do "cometa", conforme descrito por Espíndola et al., 2005. Assim, 10 mg de tecido foram homogeneizados em PBS a $4^{\circ} \mathrm{C}$. As células isoladas foram imobilizadas em matriz de agarose de baixo ponto de fusão (LMP, Sigma, EUA) sobre lâmina de microscopia contendo uma prévia camada de agarose LMP. Posteriormente, as células imobilizadas foram lisadas em solução de lise composta de $2,5 \mathrm{mM} \mathrm{NaCl}, 0.1$ mM EDTA, $10 \mathrm{mM}$ Trizma Base, $1 \%$ de Triton $\mathrm{X}-10$ e $10 \%$ DMSO com $\mathrm{pH}=10$ por 1 hora, lavadas $3 \times 10$ min em água destilada gelada. Na seqüência, as lâminas foram submetidas à eletroforese $(0,3 \mathrm{M} \mathrm{NaOH}, 1 \mathrm{mM}$ EDTA, $\mathrm{pH}>13)$ a $25 \mathrm{~V}$, durante 20 min, no escuro. A seguir, as lâminas foram neutralizadas com solução de Tris $(0,4 M$, pH 7,5). Os nucleóides resultantes foram fixados em solução de ácido tricloroacético (TCA) a $15 \%$ e corados com nitrato de prata (KIZILIAN et al., 1999). Células provenientes de tecidos de ratos normais tratadas ou não com peróxido de hidrogênio (concentração final 10\%, 5 min, à temperatura ambiente) foram utilizadas como controles positivo e negativo da técnica, respectivamente. Foram descartados da análise nucleóides com formatos de "nuvens" ou "pino de boliche" (TOLEDO et al, 2003).

O comprimento dos nucleóides foi avaliado utilizando-se sistema de análise de imagem computadorizada, composto por microscópio (Carl Zeiss Axiostar Plus, Alemanha) ao qual se encontra acoplado uma câmera de vídeo (Pixelink Megapixel 
FireWier camera 3.2, Alemanha) que se conecta a um microcomputador equipado com o programa Axio Vision 40V 4.5 (Carl Zeiss, Alemanha). Foram analisados aleatoriamente 50 nucleóides em cada lâmina, perfazendo 100 nucleóides por animal (TOLEDO et al., 2003).

\subsection{Preparação de Extrato Protéico}

Para a obtenção de extratos protéicos de frações celulares nucleares e citoplasmáticas, utilizou-se o "kit" de extração citoplasmática e nuclear NE-PER® (Pierce, EUA), segundo o manual de instruções do fabricante. Este se baseia na ruptura da membrana plasmática e liberação do conteúdo citoplasmático. Assim, após a separação do núcleo intacto do extrato citoplasmático por centrifugação, a carioteca foi lisada para a liberação do extrato nuclear.

Basicamente, pesou-se cerca de $25 \mathrm{mg}$ da mucosa colônica recolhida por ocasião da eutanásia dos ratos submetidos ao modelo experimental obtendo-se ao final do processo as frações nuclear e citoplasmática.

Posteriormente, realizou-se a quantificação da concentração de proteínas por método espectrofotométrico. Esse método está baseado no fato de que proteínas absorvem luz no comprimento de onda de $280 \mathrm{~nm}$ (UV). Para tanto, utilizou-se aparelho Gene-Quant Pro (Amersham Pharmacia biotec, EUA) ajustado para leitura a $280 \mathrm{~nm}$. A concentração de proteínas foi determinada a partir de curva padrão de albumina (concentração de 0 a $4000 \mu \mathrm{g} / \mathrm{mL}$ ). 


\subsection{Western Blotting}

Os extratos de proteina citoplasmática foram submetidos a eletroforese de gel de poliacrilamida desnaturante (SDS-PAGE), em gel a 15\% e tampão Tris-glicina $1 \mathrm{X}$ (Método de Laemmli), utilizando-se uma cuba de eletroforese vertical (Hoefer mini VE Electrophoresis System). As proteínas foram então transferidas do gel para membrana de nitrocelulose.

O bloqueio das membranas de nitrocelulose foi feito com PBS contendo $5 \%$ de leite em pó, durante uma hora. As membranas foram então incubadas com o anticorpo primário anti-Bcl-2 (Santa Cruz Biotechnology) (1:500), diluído em tampão PBS, durante uma noite a $4^{\circ} \mathrm{C}$. A membrana foi incubada com anticorpo secundário conjugado a peroxidase (HRP) durante uma hora, e a imunodetecção foi feita utilizando-se o sistema de quimioluminescência ECL (Enzimatic Chemoluminescence, Amersham Pharmacia Biotec). A membrana foi exposta a filme de raio-X (Kodak X-Omat) para o desenvolvimento das bandas.

Para se quantificar as intensidades das bandas, utilizou-se um densitômetro BIO-RAD (Modelo GS-700 Imaging Densitometer) com software especifico (Molecular Analyst). Os sinais foram quantificados em unidades arbitrárias. A membrana foi corada com corante de comassie (Comassie Blue, Pierce, Rockford), e os dados foram normalizados utilizando-se o sinal correspondente deste corante para corrigir as variações no carregamento das proteinas.

Os valores de unidades densitométricas arbitrárias assim obtidos foram expressos em relação ao grupo Normal, sendo o mesmo considerado igual a 1. 


\subsection{Análise Estatística}

O ensaio biológico foi realizado em animais devidamente aleatorizados e todos os dados obtidos foram testados quanto à distribuição normal (teste de Shapiro-Wilk) e à homogeneidade das variâncias (testes de Levene e Brown Forsythe).

Para a análise de Focos de Criptas Aberrantes, Concentração de Colesterol Plasmático Total e Teste do Cometa, quando foram satisfeitas as condições para aplicação dos testes estatísticos paramétricos de comparação de médias entre o grupo controle e os grupos experimentais, aplicou-se o teste $t$ de Student bicaudal para dados independentes. Nos casos em que não foram observadas distribuição normal e, principalmente, homogeneidade de variância, as análises estatísticas foram confirmadas pelo teste estatístico não paramétrico de Mann-Whitney.

Para a análise dos resultados de Western Blot, como os dados apresentaram distribuição normal e homogeneidade de variância, foi realizado o teste One-wayANOVA.

Os resultados foram expressos como média \pm desvio padrão e as análises estatísticas realizadas utilizando-se o programa STATISTICA 7.0, adotando-se nivel de significância de $5 \%(p \leq 0,05)$. 


\section{IV- Resultados}

: $\mathrm{BI}$, isoladamente ou em associação, durante as etapas de iniciação e pósiniciação de modelo de carcinogênese de cólon.

A Tabela 1 apresenta os pesos corpóreos iniciais e finais e o consumo de ração de ratos Wistar sem tratamento ou tratados com OM (grupo OM, controle), GO (grupo GO), BI (grupo BI) ou GO + BI (grupo Associação de $\mathrm{GO}$ e $\mathrm{Bl}$ ), durante 9 semanas consecutivas, em período compreendendo as etapas de iniciação e pósiniciação de modelo de carcinogênese de cólon.

E possível verificar que os pesos iniciais dos diferentes grupos foram bastante semelhantes, o que indica que a distribuição dos animais foi realizada de forma adequada e aleatória.

Não foram observadas diferenças estatisticamente significantes $(p>0,05)$ entre os grupos $\mathrm{OM}$ (controle), $\mathrm{GO}, \mathrm{Bl}$ e $\mathrm{GO}+\mathrm{Bl}$ quanto aos pesos corpóreos finais e consumo médio de ração ao longo das 9 semanas de experimento (Tabela 1 e Figuras 10 e 11). Esses dados podem sugerir que as dosagens utilizadas (25 $\mathrm{mg} / 100 \mathrm{~g}$ de p.c/dia. de geraniol e $16 \mathrm{mg} / 100 \mathrm{~g}$ de p.c./dia de beta-ionona) não apresentaram toxicidade aparente.

Em comparação ao grupo de animais não submetidos ao modelo, mas que apenas permaneceu nas mesmas condições que as dos demais (dependências do biotério, temperatura, ciclo luz-escuro) observam-se nos grupos submetido ao 
Geraniol, mas năo beta-ionona ou associaçăo desses isoprenóides, possui atividade quimiopreventiva em ratos submetidos a modelo de carcinogênese de cólon.

modelo de carcinogênese de cólon menores pesos corpóreos dos animais após a administração intraperitoneal de $\mathrm{DMH}$. Isso sugere que a aplicação do modelo ocorreu adequadamente. Assim, nos grupos OM (controle), GO, BI e GO + BI foram observados menores pesos corpóreos finais $(p<0,05)$ quando comparados ao grupo não submetido ao modelo.

Deve-se ressaltar que foram desprezados das análises os animais cujas mortes (33\% no grupo OM, $8 \%$ nos grupos $\mathrm{GO}$ e $\mathrm{GO}+\mathrm{BI})$ ocorreram por ocasião da entubação e que foram consideradas acidentais.

Tabela 1. Pesos corpóreos e consumo de ração de ratos Wistar sem tratamento ou tratados com OM, GO, BI ou GO + BI durante as etapas de iniciação e pós-iniciação de modelo de carcinogênese de cólon.

\begin{tabular}{|c|c|c|c|c|}
\hline Grupos & $\mathbf{n}$ & $\begin{array}{l}\text { Peso corpóreo } \\
\text { inicial* } \\
\text { (g) }\end{array}$ & $\begin{array}{l}\text { Peso corpóreo } \\
\text { final* } \\
\text { (g) }\end{array}$ & $\begin{array}{l}\text { Consumo médio de } \\
\text { ração* } \\
\text { (g/100g de p.c./dia) }\end{array}$ \\
\hline $\mathbf{N}$ & 6 & $86 \pm 5$ & $381 \pm 29$ & $11 \pm 0,4$ \\
\hline OM & 8 & $82 \pm 6$ & $327 \pm 22^{\mathrm{a}}$ & $10 \pm 0,2$ \\
\hline GO & 11 & $84 \pm 3$ & $332 \pm 22^{a}$ & $10 \pm 0,2$ \\
\hline BI & 12 & $84 \pm 3$ & $326 \pm 16^{a}$ & $10 \pm 0,2$ \\
\hline $\mathrm{GO}+\mathrm{BI}$ & 11 & $85 \pm 3$ & $324 \pm 26^{a}$ & $10 \pm 0,2$ \\
\hline
\end{tabular}


Geraniol, mas não beta-ionona ou associação desses isoprenóides, possui atividade quimiopreventiva em ratos submetidos a modelo de carcinogênese de cólon.

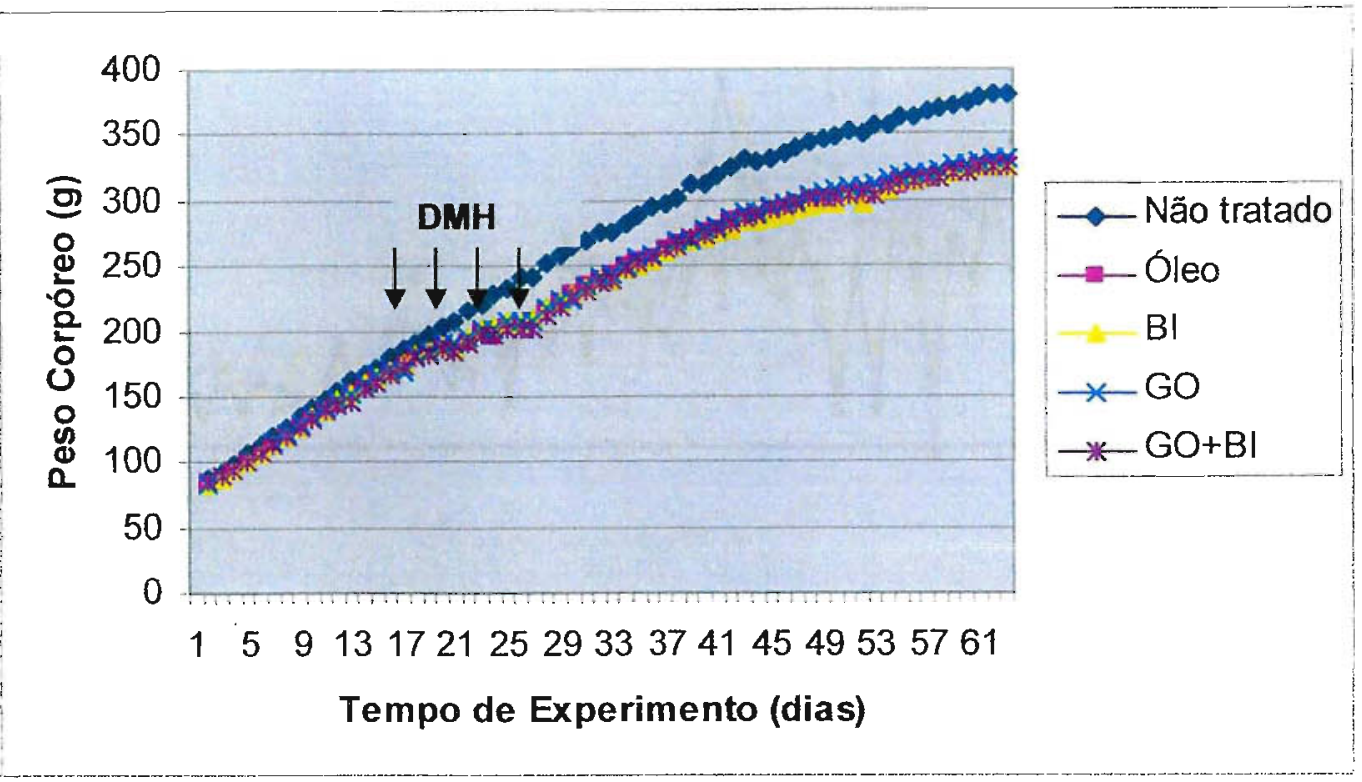

Figura 10. Evolução do peso corpóreo de ratos Wistar sem tratamento ou tratados com $O M, G O, B I$ ou GO + BI durante as etapas de iniciação e pós-iniciação de modelo de carcinogênese de cólon. 
Geraniol, mas não beta-ionona ou associação desses isoprenóides, possui atividade quimiopreventiva em ratos submetidos a modelo de carcinogênese de cólon.

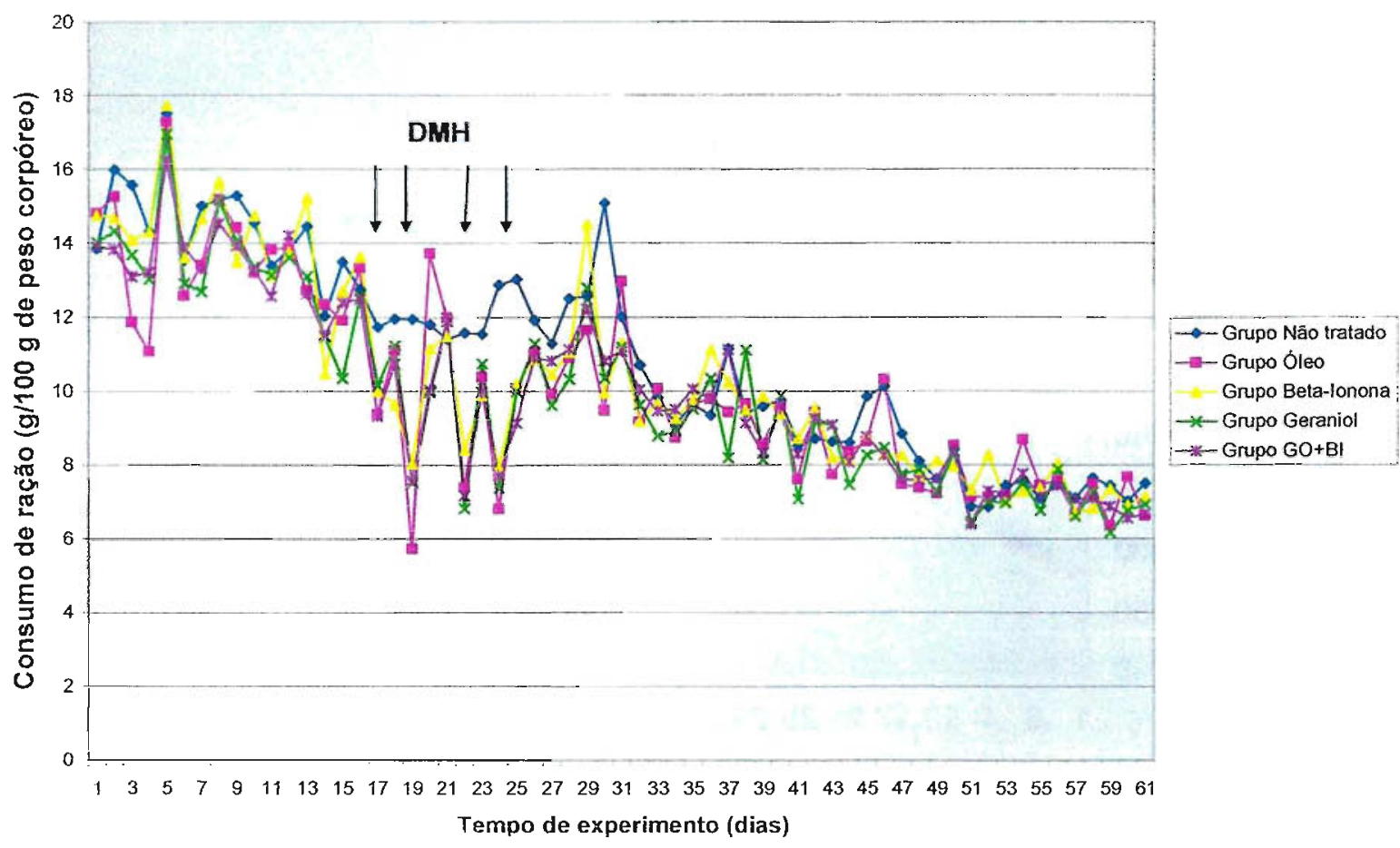

Figura 11. Consumo de ração de ratos Wistar sem tratamento ou tratados com $\mathrm{OM}, \mathrm{GO}, \mathrm{Bl}$ ou $\mathrm{GO}+$ $\mathrm{BI}$ durante as etapas de iniciação e pós-iniciação de modelo de carcinogênese de cólon

\subsection{Pesquisa de Focos de Criptas Aberrantes (FCAs)}

O cólon de cada animal foi corado com azul de metileno e, então. analisadó quanto ao número total, à multiplicidade (FCAs < ou $\geq 4$ criptas) e localização (cólon proximal ou distal) de focos contendo criptas maiores, com camada epitelial mais espessa, abertura luminal alongada e coradas mais intensamente que aquelas a seu redor, assim denominados de Focos de Criptas Aberrantes (FCAs) (Figura 12). 
Geraniol, mas não beta-ionona ou associação desses isoprenóides, possui atividade quimiopreventiva em ratos submetidos a modelo de carcinogênese de cólon.

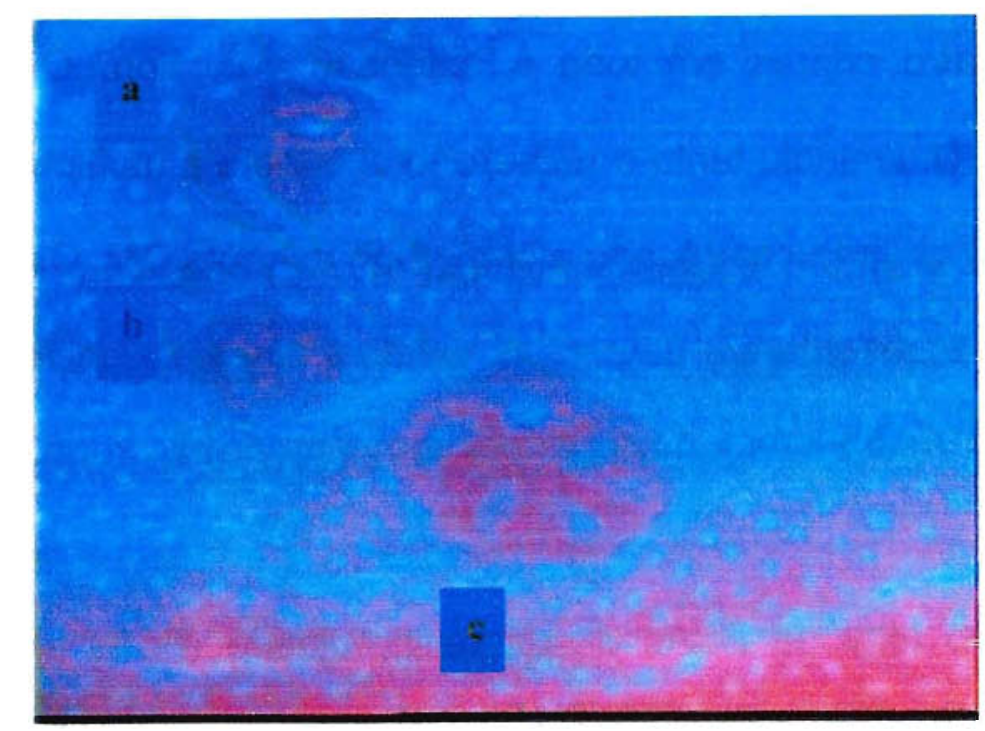

Figura 12: Focos de Criptas Aberrantes contendo 3 (a), 4(b) e 6 (c) criptas, respectivamente. de cólon de rato Wistar submetido ao modelo de carcinogênese induzida por DMH quando corado com Azul de Metileno (Objetiva 40X).

Tabela 2: Número total de FCAs e sua multiplicidade (FCAs $<$ ou $\geq 4$ criptas) presentes em cólons de ratos Wistar tratados com OM, GO, BI ou GO + Bl durante as etapas de iniciação e pós-iniciação de modelo de carcinogênese de cólon.

\section{Extensão Completa do Cólon}

\begin{tabular}{lcccc}
\hline Grupos & $\mathbf{n}$ & $\mathbf{n}^{\circ}$ FCAs totais & $\mathbf{n}^{\circ}<\mathbf{4}$ & $\mathbf{n}^{\circ} \geq \mathbf{4}$ \\
OM & $\mathbf{8}$ & $123 \pm 30$ & $103 \pm 48$ & $21 \pm 9$ \\
GO & $\mathbf{1 1}$ & $92 \pm 35^{\mathrm{a}}$ & $80, \pm 34$ & $12 \pm 6^{\mathrm{a}}$ \\
BI & $\mathbf{1 2}$ & $120 \pm 45$ & $104 \pm 37$ & $19 \pm 13$ \\
BI + GO & $\mathbf{1 1}$ & $1256 \pm 23$ & $103 \pm 19$ & $23 \pm 9$ \\
\hline
\end{tabular}

$\mathrm{n}=$ número de animais;

$O M=$ óleo de milho (controle) $(n=8) ; G O=$ geraniol $(n=11) ; B I=$ beta-ionona $(n=12) ; G O+B I(n=11)$; $\mathrm{DP}=$ desvio padrão; FCAs $=$ Focos de Criptas Aberrantes

${ }^{a}$ diferença estatisticamente significante em relação ao grupo OM (controle) $(p \leq 0,05)$, segundo o teste $t$ de Student para amostras não pareadas 
Geraniol, mas não beta-ionona ou associação desses isoprenóides, possui atividade quimiopreventiva em ratos submetidos a modelo de carcinogénese de cólon.

A Tabela 2 apresenta o número de FCAs contendo número menor e maior ou igual do que quatro criptas em toda a extensão do cólon. Observa-se que o tratamento com GO diminuiu tanto o número total quanto a multiplicidade dos FCAs (FCAs $\geq 4$ criptas) quando comparado a seu grupo controle $\mathrm{OM}$. Os grupos $\mathrm{BI}$ e $\mathrm{BI}+$ GO ( $p>0,05)$ não apresentaram diferenças estatisticamente significantes quanto ao número total de FCAs e FCAs $\geq 4$ criptas em comparação ao grupo controle OM.

Tabela 3: Número total de FCAs e sua multiplicidade (FCAs $<$ ou $\geq 4$ criptas) presentes no cólon distal de ratos Wistar tratados com OM, GO, BI ou GO + BI durante as etapas de iniciação e pós-iniciação de modelo de carcinogênese de cólon

\section{Cólon Distal}

\begin{tabular}{|c|c|c|c|c|}
\hline Grupos & $\mathbf{n}$ & $n^{\circ}$ FCAs totais & $n^{0}<4$ & $n^{\circ} \geq 4$ \\
\hline OM & 8 & $103 \pm 24$ & $86 \pm 21$ & $17 \pm 8$ \\
\hline GO & 11 & $66 \pm 43^{a}$ & $58 \pm 41$ & $9 \pm 5^{a}$ \\
\hline BI & 12 & $91 \pm 38$ & $77 \pm 29$ & $14 \pm 11$ \\
\hline $\mathrm{BI}+\mathrm{GO}$ & 11 & $96 \pm 17$ & $77 \pm 14$ & $19 \pm 8$ \\
\hline
\end{tabular}

$\mathrm{n}=$ número de animais;

$\mathrm{OM}=$ óleo de milho (controle) $(n=8) ; \mathrm{GO}=$ geraniol $(n=11) ; B I=$ beta-ionona $(n=12) ; \mathrm{GO}+\mathrm{BI}(\mathrm{n}=11)$; $\mathrm{DP}=$ desvio padrão; FCAs $=$ Focos de Criptas Aberrantes

a diferença estatisticamente significante em relação ao grupo $\mathrm{OM}$ (controle) $(p \leq 0,05)$, segundo o teste $t$ de Student para amostras não pareadas

De acordo com a Tabela 3 observa-se que o tratamento com GO diminuiu $(p \leq 0,05)$ tanto o número total quanto o número de $F C A s \geq 4$ criptas quando comparado a seu grupo controle $\mathrm{OM}$ no cólon distal. Os grupos $\mathrm{BI}$ e $\mathrm{GO}+\mathrm{BI}$ $(p>0,05)$ não apresentaram diferenças estatisticamente significantes quanto ao 
número total de FCAs e FCAs $\geq 4$ criptas no cólon distal em comparação ao grupo controle OM.

Tabela 4: Número total de FCAs e sua multiplicidade (FCAs < ou $\geq 4$ criptas) presentes no cólon proximal de ratos Wistar tratados com $\mathrm{OM}, \mathrm{GO}, \mathrm{BI}$ ou $\mathrm{GO}+\mathrm{BI}$ durante as etapas de iniciação e pós-iniciação de modelo de carcinogênese de cólon

\begin{tabular}{lcccc}
\hline \multicolumn{5}{c}{ Cólon Proximal } \\
Grupos & $\mathbf{n}$ & $\mathbf{n}^{\mathbf{0}}$ FCAs totais & $\mathbf{n}^{\circ}<4$ & $\mathbf{n}^{\mathbf{0}} \geq \mathbf{4}$ \\
\hline OM & $\mathbf{8}$ & $21 \pm 12$ & $17 \pm 10$ & $3 \pm 3$ \\
GO & $\mathbf{1 1}$ & $26 \pm 18$ & $23 \pm 16$ & $4 \pm 3$ \\
BI & 12 & $29 \pm 13$ & $25 \pm 11$ & $4 \pm 3$ \\
BI + GO & 11 & $29 \pm 16$ & $26 \pm 13$ & $4 \pm 3$ \\
\hline
\end{tabular}

$n=$ número de animais;

$\mathrm{OM}=$ óleo de milho (controle) $(n=8) ; \mathrm{GO}=$ geraniol $(\mathrm{n}=11) ; \mathrm{BI}=$ beta-ionona $(\mathrm{n}=12) ; \mathrm{GO}+\mathrm{BI}(\mathrm{n}=11)$; $\mathrm{DP}=$ desvio padrão; FCAs = Focos de Criptas Aberrantes

Teste-t de Student para amostras não pareadas $(p \leq 0,05)$.

Já de acordo com a Tabela 4 observa-se que os grupos $\mathrm{GO}, \mathrm{Bl}$ e $\mathrm{Bl}+\mathrm{GO}$ $(p>0,05)$ não apresentaram diferenças estatisticamente significantes quanto ao número total de FCAs e FCAs $\geq 4$ criptas em relação ao grupo controle OM no cólon proximal. 
Geraniol, mas não beta-ionona ou associação desses isoprenóides, possui atividade quimiopreventiva em ratos submetidos a modelo de carcinogênese de cólon.

4.3 Concentração plasmática de colesterol total de animais tratados com geraniol ou beta-ionona, isoladamente ou em associação, durante as etapas de iniciação e pós-iniciação de modelo de carcinogênese de cólon

A Tabela 5 apresenta os resultados referentes às concentrações plasmáticas de colesterol total de ratos Wistar sem tratamento ou tratados com $\mathrm{OM}, \mathrm{GO}, \mathrm{BI}$ ou $\mathrm{GO}+\mathrm{BI}$ durante as etapas de iniciação e pós-iniciação de modelo de carcinogênese de cólon.

De acordo com a Tabela 5 , verifica-se que a concentração plasmática de colesterol total foi mais elevada $(p \leq 0,05)$ no grupo OM (controle) em comparação ao grupo N.

Já em comparação ao grupo OM, o grupo Bl, mas não os grupos GO e GO + BI, apresentou menor concentração plasmática de colesterol total $(p \leq 0,05)$. 
Tabela 5 - Concentração de Colesterol Plasmático Total de ratos Wistar sem tratamento ou tratados com OM, GO, BI ou GO+BI durantes as etapas de iniciação e pós-iniciação de modelo de carcinogênese de cólon

Grupos n

\section{Colesterol Plasmático Total ${ }^{\star}(\mathrm{mg} / \mathrm{dL})$}

\begin{tabular}{|c|c|c|}
\hline $\mathbf{N}$ & 6 & $43 \pm 2$ \\
\hline OM & 8 & $62 \pm 15^{a}$ \\
\hline GO & 10 & $51 \pm 8$ \\
\hline BI & 11 & $47 \pm 7^{b}$ \\
\hline $\mathrm{GO}+\mathrm{BI}$ & 11 & $59 \pm 7$ \\
\hline \multicolumn{3}{|c|}{$\begin{array}{l}\mathrm{n}=\text { número de animais; } \\
\mathrm{N}=\text { não tratado; } \mathrm{OM}=\text { óleo de milho (controle); } \mathrm{GO}=\text { geraniol; } \mathrm{BI}=\text { beta-ionona, } \mathrm{GO}+\mathrm{BI} \\
{ }^{*} \text { média e desvio-padrão }\end{array}$} \\
\hline
\end{tabular}


Geraniol, mas năo beta-ionona ou associação desses isoprenóides, possui atividade quimiopreventiva em ratos submetidos a modelo de carcinogênese de cólon.

\begin{abstract}
4.4 Avaliação de Danos no DNA em mucosas colônicas de animais tratados com geraniol ou beta-ionona, isoladamente ou em associação, durante as etapas de iniciação e pós-iniciação de modelo de carcinogênese de cólon.
\end{abstract}

A Tabela 6 apresenta o comprimento dos "nucleóides" em $\mu$ m de amostras da mucosa colônica dos ratos Wistar tratados com OM, GO, BI ou GO + Bl durante as etapas de iniciação e pós-iniciação de modelo de carcinogênese de cólon e, também, das mucosas de ratos normais $(\mathrm{N})$ tratados ou não com peróxido de hidrogênio (controles positivo e negativo, respectivamente). 
Geraniol, mas năo beta-ionona ou associaçăo desses isoprenóides, possui atividade quimiopreventiva em ratos submetidos a modelo de carcinogénese de cólon.

Tabela 6. Comprimento dos "nucleóides" de amostras de mucosas colônicas de ratos Wistar tratados com OM, GO, BI ou GO + Bl durante as etapas de iniciação e pós-iniciação de modelo de carcinogênese de cólon e, também, das mucosas de ratos normais $(\mathrm{N})$, tratados ou não com peróxido de hidrogênio $(\mathrm{PH}$ - Controle Positivo).

\begin{tabular}{lcc} 
Grupos & n & $\begin{array}{c}\text { Comprimento dos "nucleóides" } \\
(\mu \mathrm{m})^{\star}\end{array}$ \\
\hline (PH) & 6 & $86 \pm 7$ \\
$M$ & 6 & $178 \pm 11^{\mathrm{a}}$ \\
& 8 & $114 \pm 5^{\mathrm{a}}$ \\
& 11 & $90 \pm 6^{\mathrm{b}}$ \\
& 12 & $89 \pm 6^{\mathrm{b}}$ \\
$\mathrm{O}+\mathrm{BI}$ & 11 & $88 \pm 4^{\mathrm{b}}$
\end{tabular}

$\mathrm{n}=$ número de animais;

$\mathrm{N}$ = comprimento dos nucleóides de amostras de mucosa colônica de ratos não submetidos ao modelo e não tratadas com peróxido de hidrogênio (controle negativo da técnica do cometa).

$N(\mathrm{PH})=$ comprimento dos nucleóides de amostras de mucosa colónica de ratos não submetidos ao modelo e tratadas com peróxido de hidrogênio (controle positivo da técnica do cometa).

$\mathrm{OM}=$ óleo de milho (controle); GO (geraniol); BI (beta-ionona); GO + BI

*média \pm desvio-padräo da média.

${ }^{a}$ diferença estatisticamente significante em relação ao grupo $\mathbf{N}$ (não submetido a qualquer tratamento) $(p<0,05)$, segundo o teste $t$ de Student para amostras năo pareadas.

'diferença estatisticamente significante em relação ao grupo OM (controle) $(p \leq 0,05)$, segundo o teste $t$ de Student para amostras não pareadas.

É possivel observar que amostras de mucosas colônicas de ratos não submetidos ao modelo tratadas com peróxido de hidrogênio [grupo $\mathrm{N}(\mathrm{PH})$ ], controles positivos da técnica do "cometa", apresentaram "nucleóides" de maior comprimento 
Geraniol, mas não beta-ionona ou associação desses isoprenóides, possui atividade quimiopreventiva em ratos submetidos a modelo de carcinogênese de cólon.

$(p<0,05)$ quando comparadas àquelas não tratadas com o agente oxidante em questão (grupo N, controle negativo da técnica do cometa).

O grupo OM (controle), quando comparado ao grupo $\mathrm{N}$, apresentou "nucleóides" de maior comprimento $(p<0,05)$. Já os grupos $\mathrm{GO}, \mathrm{BI}$ e $\mathrm{GO}+\mathrm{BI}$, quando comparados ao grupo OM (controle), apresentaram "nucleóides" de menor comprimento $(p<0,05)$.

Exemplos dos nucleóides observados encontram-se apresentados na Figura 13.
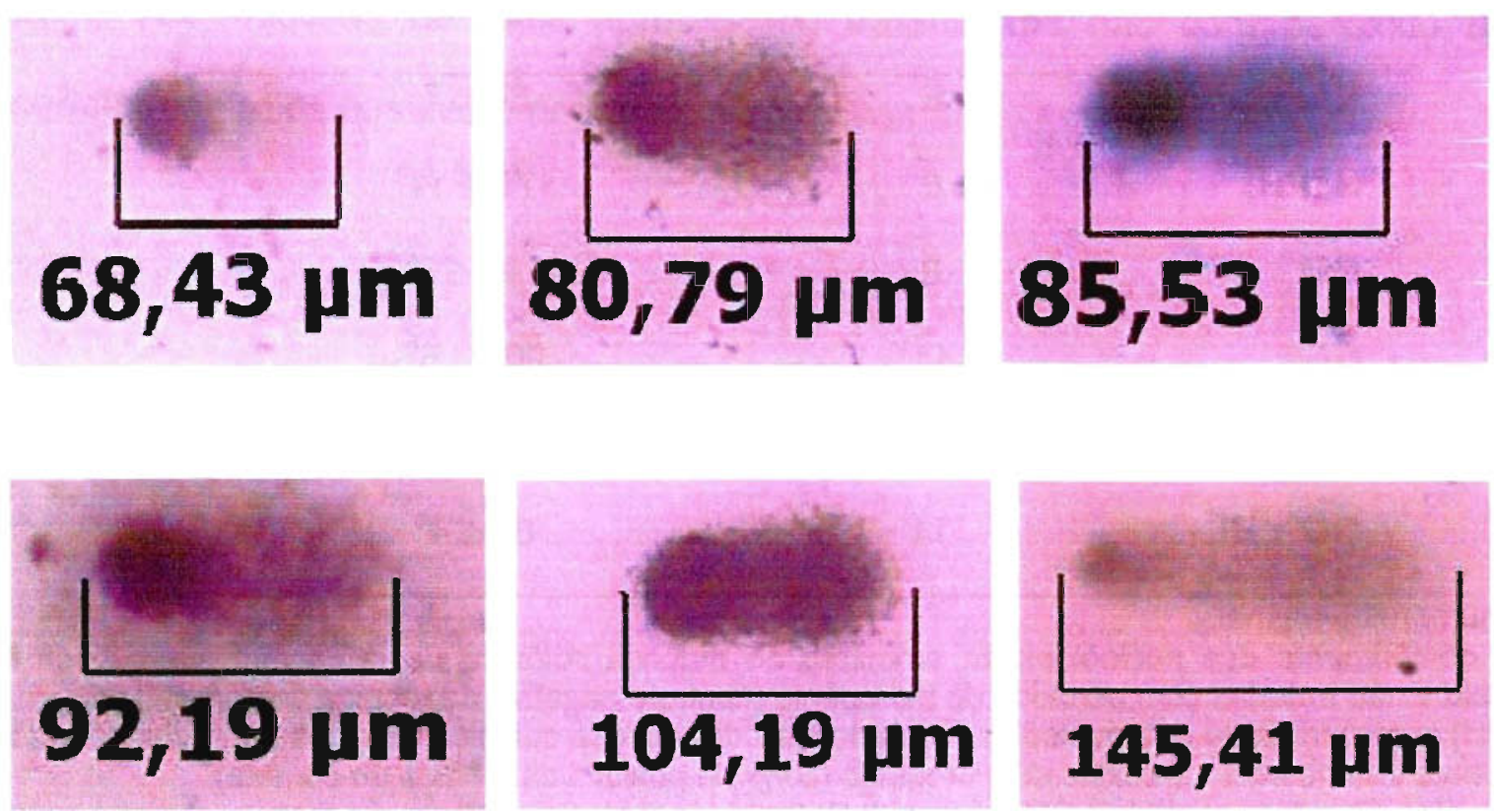

Figura 13: Exemplos de "cometas" de células de mucosa colônica de ratos Wistar e submetidos a modelo de carcinogênese de cólon com os diferentes tratamentos. [Objetiva de 10X] 
4.5 Expressão de $\mathrm{Bcl}-2$ de extratos citoplasmáticos de mucosa colônica de animais tratados com geraniol ou beta-ionona, isoladamente ou em associação, durante as etapas de iniciação e pós-iniciação de modelo de carcinogênese de cólon

A avaliação da expressão de $B c /-2$ foi realizada por meio da técnica de "Western Blotting". Foram realizados 3 "imunoblots", cada um contendo amostras de proteínas de extratos citoplasmáticos da mucosa colônica de 2 animais de cada grupo (com exceção do grupo não submetido ao modelo). Assim, no total, a expressão de $\mathrm{Bcl}-2$ foi analisada em 6 animais por grupo.

A figura 14 ilustra o resultado de 1 dos 3 "imunoblots" realizados, em que se observa a banda de interesse com $27 \mathrm{KDa}$, referente à proteína anti-apoptótica $\mathrm{Bcl}$ 2.

A leitura da intensidade das bandas foi efetuada por meio de densitometria. Os valores obtidos foram normalizados de acordo com a quantidade de proteina de extrato citoplasmático carregada nos respectivos géis. Os resultados finais foram expressos em unidades densitométricas arbitrárias e graficamente visualizados na Figura 15. 
Geraniol, mas não beta-ionona ou associação desses isoprenóides, possui atividade quimiopreventiva em ratos submetidos a modelo de carcinogènese de cólon.

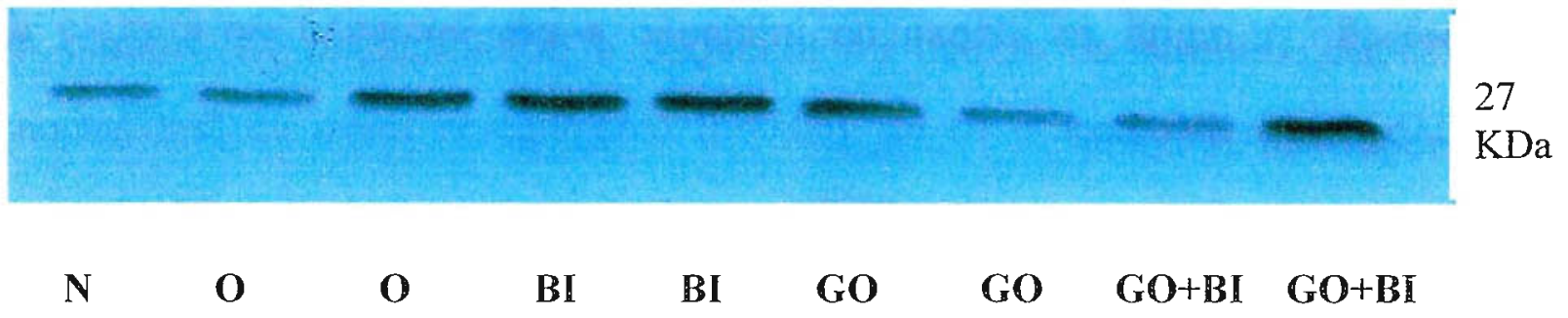

Figgura 14. Expressão de $B c /$-2 avaliada por "western blot" utilizando-se amostras de proteínas de extratos citiplasmáticos de mucosas colônicas de ratos Wistar sem tratamento ou tratados com OM, $\mathrm{BI}, \mathrm{GO}$ ou $\mathrm{GO}+\mathrm{Bl}$ durante as etapas de iniciação e pós-iniciação de modelo de carcinogênese de cólon

$\mathrm{N}=$ não tratados; $\mathrm{OM}=$ óleo de milho (controle); $\mathrm{GO}=$ geraniol; $\mathrm{Bl}$ = beta-ionona; $\mathrm{GO}+\mathrm{BI}=$ geraniol e beta-ionona ( $n=6$ animais em todos os grupos).

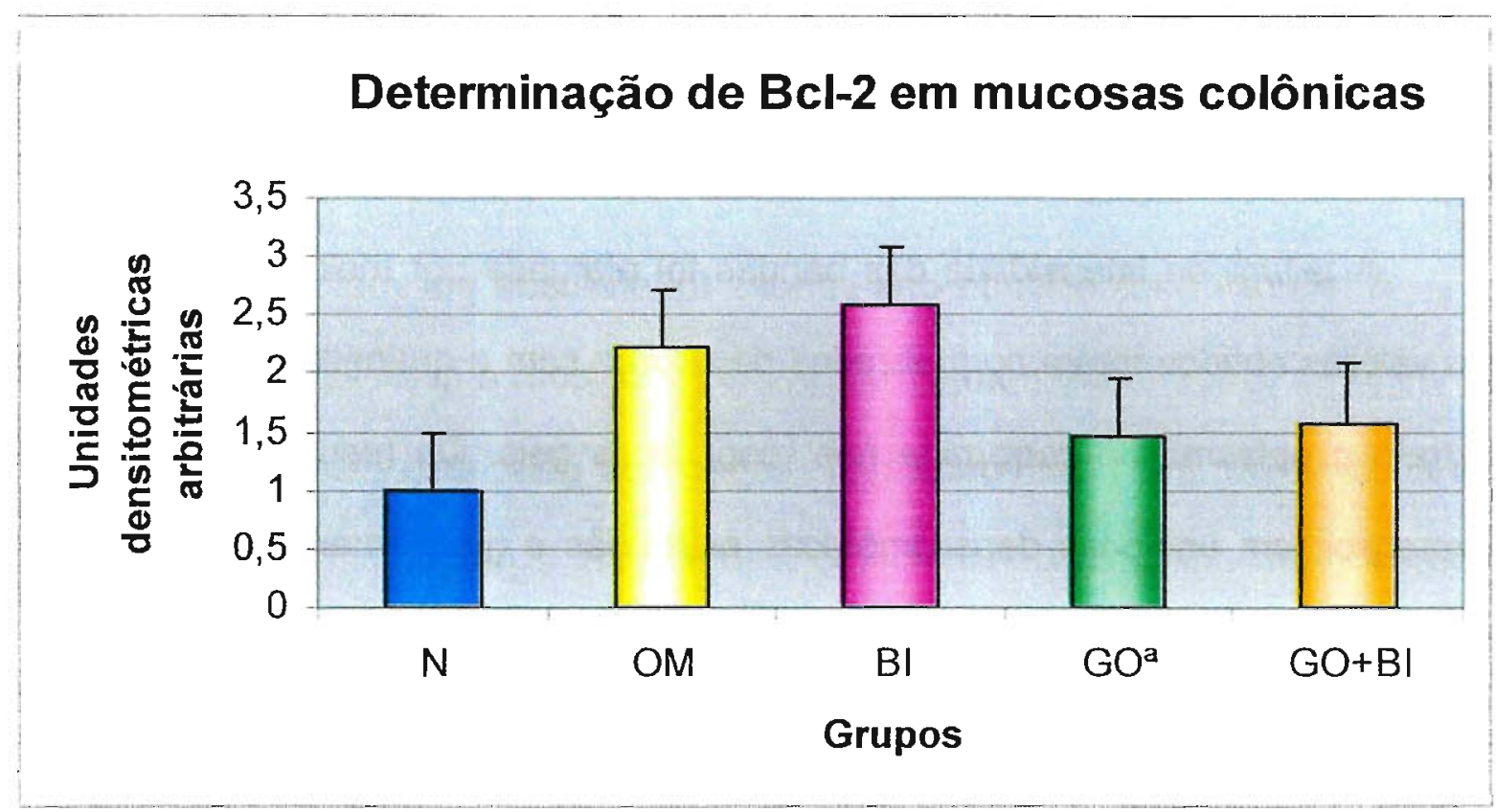

Figura 15. Expressão normalizada dos valores obtidos por meio de "western blotting" para a proteína $\mathrm{BCl}-2$ entre nos diferentes grupos. Os valores (média \pm desvio padrão) estão expressos em unidades densitométricas arbitrárias dos grupos submetidos ao modelo de carcinogênese de cólon em relação ao grupo N, considerado como 1.

adiferença estatisticamente significante em relação ao grupo $O M$ (não submetido a qualquer tratamento) $(p \leq 0,05)$, segundo o teste $t$ de Student para amostras não pareadas. 
$\mathrm{N}=$ não tratados; $\mathrm{OM}=$ óleo de milho (controle); $\mathrm{GO}=$ geraniol; $\mathrm{BI}=$ beta-ionona; $\mathrm{GO}+\mathrm{BI}=$ geraniol $\mathrm{e}$ beta-ionona ( $n=6$ animais em todos os grupos).

Detectou-se a expressão de $B c /-2$, em nivel de proteína, em ratos sem tratamento ou tratados com $\mathrm{OM}, \mathrm{BI}, \mathrm{GO}$ ou $\mathrm{BI}+\mathrm{GO}$ durante as fases de iniciação e pós-iniciação de modelo de carcinogênese de cólon.

Após normalização das expressões de $\mathrm{Bcl}-2$ de acordo com a quantidade de proteína carregada no gel e ajuste dos resultados como porcentagem de expressão de $B c l-2$ em relação à expressão observada no grupo não tratado $(100 \%)$, foi observada menor expressão no tratamento com GO em comparação ao grupo controle OM. 
Geraniol, mas não beta-ionona ou associação desses isoprenóides, possui atividade quimiopreventiva em ratos submetidos a modelo de carcinogénese de cólon.

\section{V- Discussão:}

Estudos epidemiológicos e experimentais têm sugerido que o consumo de frutas e hortaliças está inversamente associado ao risco de desenvolvimento de câncer, principalmente o de cólon (SURH, 2003, MATHEW, 2004; BARTH, 2005). Muitos dos efeitos protetores desses alimentos têm sido atribuídos aos metabólitos secundários biologicamente ativos de plantas (BARTH, 2005), com importante destaque aos derivados da via do mevalonato, também chamados isoprenóides (MO; ELSON, 2004).

Assim, o principal objetivo desse estudo foi o de avaliar se os isoprenóides $\mathrm{GO}$, presente em óleos de plantas aromáticas, e $\mathrm{BI}$, presente em uvas e vinhos, teriam efeito quimiopreventivo quando administrados isoladamente ou em associação a ratos Wistar, durante as etapas de iniciação e pós-iniciação de modelo de carcinogênese de cólon.

As doses dos isoprenóides utilizadas no presente estudo foram escolhidas a partir de trabalhos anteriores de nosso grupo, nos quais foram administrados $\mathrm{GO}$ e BI durante as fases de iniciação e promoção inicial da hepatocarcinogêse em ratos (ONG et al., 2005; ESPÍNDOLA et al., 2005). Apesar da existência de alguns trabalhos na literatura demonstrando a atividade anti-neoplásica desses compostos in vitro, não há relatos sobre a ação dessas substâncias especificamente em modelo de carcinogênese de cólon in vivo.

Inicialmente, é importante destacar que não houve, quando da aplicação do modelo, diferenças no crescimento e consumo de ração dos animais dos grupos $\mathrm{GO}, \mathrm{Bl}$ e GO + BI em comparação aos animais do grupo OM (controle) (Tabela 1 e 
Geraniol, mas năo beta-ionona ou associação desses isoprenóides, possui atividade quimiopreventiva em ratos submetidos a modelo de carcinogênese de cólon.

Figuras 10 e 11). Isso sugere que não houve maior toxicidade e os diferentes efeitos constatados por parte do GO e BI nesse experimento, e discutidos a seguir, não devem estar relacionados a um menor consumo de calorias por parte dos animais.

FCAs estão presentes em roedores tratados com DMH e também em humanos com adenomas elou adenocarcinomas de cólon e, assim, são amplamentes aceitos como lesões pré-neoplásicas (BIRD; GOOD, 2000). Considera-se que FCAs precedem o desenvolvimento de adenomas (precursores do câncer de cólon) e que essas lesões representem estágios iniciais da carcinogênese de cólon. A transição FCA-adenoma é bem aceita devido ao fato destas lesões apresentarem mutações genéticas comuns entre si. Além disso, displasia, um marcador que identifica maior risco de progressão ao câncer, e alterações bioquímicas têm sido observadas tanto em FCAs induzidos por AOM ou DMH como também em FCAs humanos (MAURIN et al, 2006). Ainda, a indução e o desenvolvimento de FCAs podem ser inibidos por agentes quimiopreventivos e, com isso, oferecer informações importantes que possibilitem que moduladores da carcinogênese sejam identificados (BIRD, 1995, BIRD; GOOD, 2000).

No presente estudo foi avaliada a incidência de FCAs no cólon de ratos submetidos ao modelo de carcinogênese experimental induzida por DMH tendo-se observado (Tabelas 2, 3 e 4) que o tratamento com GO reduziu o número de FCAs totais (de diferentes tamanhos) e aqueles com número maior ou igual do que 4 criptas no cólon distal.

Modelos que utilizam o carcinógeno $\mathrm{DMH}$ revelam que o número de FCAs aumenta com decorrer do tempo. Isso sugere que alguns deles se desenvolvem 
Geraniol, mas não beta-ionona ou associação desses isoprenóides, possui atividade quimiopreventiva em ratos submetidos a modelo de carcinogênese de cólon.

mais rapidamente do que outros. Esses focos também podem sofrer processo de remodelação, sendo que os menores (focos contendo 1, 2 ou 3 criptas) regridem $e$ os maiores (focos contendo 4 ou mais criptas) progridem para o câncer. É muito importante considerarmos que existem diferenças biológicas naqueles FCAs que exibem diferentes multiplicidades, que estes são regulados diferencialmente e que a transição de microadenomas para adenocarcinomas pode ser retardada por compostos presentes na alimentação. FCAs com maior número de criptas por foco representam lesões mais avançadas e agressivas e apresentam menor capacidade em responder a agentes quimiopreventivos ou quimioterapêuticos (MCLELLAN; BIRD, 1991; BIRD, 1995, RONCUCCI, 2000).

FCAs aumentam seu tamanho por um mecanismo denominado de fissão da cripta. Quando o indice de proliferação na região das células-tronco supera um determinado limiar, a cripta ramifica-se a partir de sua base gerando duas novas criptas (RONUCCl et al, 2000). Com isso, o número de criptas presentes em cada foco, também chamado de multiplicidade, pode ser um importante parâmetro para avaliação do crescimento e progressão de FCAs (CHENG et al, 2003). Dessa forma, focos contendo maior número de criptas estão envolvidos com o desenvolvimento de neoplasias no cólon, já que a maioria dos FCAs regride e somente grandes focos persistem, aumentam sua multiplicidade e desenvolvem-se em adenocarcinomas (RONUCCl et al, 2000, VOLATE et al, 2005). Assim, o número de criptas por foco é um indicativo da transformação maligna e têm sido observadas evidências de neoplasias que se originam de grandes FCAs em carcinogênese de cólon induzida por AOM ou DMH (MAURIN et al, 2006). 
Estudos envolvendo a administração de ácido cólico (ácido biliar primário conhecido como promotor da carcinogênese de cólon) demonstraram que a multiplicidade de FCA está mais relacionada com a incidência de neoplasias do que o número total de FCAs (SHIRTLIFF; BIRD, 1996). Surpreendentemente, os animais alimentados com ração contendo ácido cólico apresentaram menor número de FCAs em comparação ao grupo controle mas, por outro lado, desenvolveram maior número de neoplasias colônicas. Entretanto, foi observado que a maior proporção dos FCAs do grupo alimentado com ácido cólico exibiram maior multiplicidade. Com isso, acredita-se que esse ácido biliar tenha induzido especificamente FCAs com fenótipo de crescimento avançado (FCAs de maiores multiplicidades), inibindo e/ou remodelando os FCAs de menores multiplicidades. Esses achados demonstram que FCAs de maior multiplicidade são fenotipicamente diferentes daqueles menores (FCAs contendo de 1-3 criptas) e essa heterogeneidade morfológica pode indicar estágios biológicos e características de crescimento diferentes em cada uma dessas lesões (à medida que FCAs $\geq 4$ ou $<4$ criptas apresentam respostas distintas a um mesmo agente modulador da carcinogênese) (SHIRTLIFF; BIRD, 1996). Dessa forma, FCAs $\geq 4$ criptas foram menos sensiveis ao efeito da ração contendo ácido cólico e, com isso, tornaram-se mais propensos a progredirem à formação de neoplasias. Assim, esses resultados suportam a noção que FCAs com maior multiplicidade representam lesões com aumento do potencial neoplásico (BIRD; GOOD, 2000).

FCAs aparecem mais rápida e precocemente no cólon distal do que no cólon proximal (BIRD, 1995). Dados epidemiológicos, fisiológicos e embriológicos sugerem que o cólon proximal e o cólon distal podem ser considerados duas entidades 
Geraniol, mas não beta-ionona ou associação desses isoprenoides, possui atividade quimiopreventiva em ratos submetidos a modelo de carcinogênese de colon

anatômica e funcionalmente distintas. Diferenças entre segmentos colônicos normais favorecem a progressão através de diferentes caminhos no processo de desenvolvimento do câncer de cólon. Eles incluem análise de riscos associados com diversos fatores ambientais e genéticos que diferem nos cânceres de cólon proximal e do cólon distal (IACOPETTA et al., 2002). Carcinomas que se originam em cada um destes segmentos colônicos exibem diferenças de incidências também de acordo com a região geográfica, idade e sexo. Além disso, observações de síndromes hereditárias, como Câncer Colorretal Hereditário sem Polipose que ocorrem predominantemente no cólon proximal (caracterizada pela presença de instabilidade de microssatélites) e Polipose Adenomatosa Familial que ocorrem em maior proporção no cólon distal (caracterizada pela presença de instabilidade cromossômica), podem indicar a existência de duas categorias de neoplasias baseadas no sítio de origem no intestino grosso onde existem alterações genéticas distintas (IACOPETTA et al., 2002; GERVAZ et al., 2004). Também foram observadas diferenças entre os padrões de proliferação em criptas do cólon proximal e distal (por meio de imunoistoquímica para 5-bromo-2-desoxiuridina), onde a localização da região de células-tronco e a direção da migração do colonócito é diferente em cada uma das regiões. O cólon distal apresenta maior índice de proliferação e aumento do tamanho da zona proliferativa de suas criptas quando comparado ao proximal. Este fato pode estar associado com o aumento da susceptibilidade ao desenvolvimento de neoplasias na região distal (MA et al., 2002).

Da mesma forma, um estudo de carcinogênese de cólon induzida quimicamente em ratos demonstrou possibilidades distintas: uma delas envolveu a formação de neoplasia sem passar pelo estágio pré-neoplásico de FCA e resultou 
Geraniol, mas não beta-ionona ou associação desses isoprenóides, possui atividade quimiopreventiva em ratos submetidos a modelo de carcinogênese de cólon.

no desenvolvimento de carcinomas mucinosos pouco diferenciados no cólon proximal; enquanto a outra já envolveu a seqüênica FCA-adenoma-adenocarcinoma no cólon transverso e, principalmente, no distal. Essas diferentes possibilidades podem refletir as diferenças biológicas existentes entre as duas porções do cólon e representam caminhos separados da carcinogênese. Além disso, esses achados sugerem que FCA é um estágio intermediário da carcinogênese de cólon somente no caso de neoplasias bem diferenciadas encontradas no cólon distal e não daquelas pouco diferenciadas (como carcinomas secretores de mucinas), encontradas no cólon proximal (PARK et al, 1997). Cameron et al, reportaram que nenhum FCA foi encontrado no cólon proximal de 1 a 5 semanas após a administração de DMH. Com isso, os autores concluíram que carcinomas que se desenvolvem nessa região não se originaram a partir de um FCA e que, conseqüentemente, a localização, o número e o tamanho dos FCAs que são formados logo após à exposição de DMH nâo se correlacionam com a localização nem com a incidência de carcinomas que eventualmente se originam no cólon proximal. Dessa maneira, FCAs são mais restritos ao cólon distal em modelo de carcinogênese de cólon utilizando $\mathrm{DMH}$, onde as lesões neoplásicas têm mostrado seguir a seqüência FCA-adenoma-carcinoma. Assim, seria interessante que estudos futuros pudessem relacionar a incidência de FCA com a porção do cólon encontrada e com o tipo histológico de neoplasia presente em cada uma delas (PARK et al, 1997).

Dessa forma, tanto a formação de FCA quanto o desenvolvimento de câncer de cólon ocorrem em maior proporção na região do cólon distal de ratos tratados com o carcinógeno DMH, o que representa os mesmos eventos biológicos vistos em 
seres humanos (RODRIGUES et al., 2002) e que também pode ser observado no presente trabalho.

Isoprenóides já foram testados em cultura de células e em roedores, a maioria deles, neste último caso, durante ou após a administração do carcinógeno de cólon (WARGOVICH et al., 2000).

Em estudos in vitro observou-se que tratamento com BI inibiu a proliferação de células de adenocarcinomas de cólon Caco-2, resultando em bloqueio do ciclo celular em G1 e em estímulo da apoptose. Além disso, BI também foi capaz de inibir a proliferação de fibroblastos (CCD-18Co) de cólon humanos induzindo apoptose, bloqueando células na fase $\mathrm{G} 1$ do ciclo celular $\mathrm{e}$, ainda, inibindo a atividade da enzima HMGCoA redutase (MO; ELSON, 1999).

Baseando-se em seus efeitos na proliferação da linhagem celular Caco-2 de adenocarcinoma de cólon humano, verificou-se que tratamento com GO causou inibição da proliferação celular, com acúmulo de células na fase $\mathrm{S}$ do ciclo celular e, simultaneamente, inibição da síntese de DNA (CARNESECCHI et al., 2001).

Em estudos prévios com animais de experimentação, foi observada ação inibitória do álcool perilílico em modelo de carcinogênese de cólon induzida pelo azoximetano em ratos F-344 machos associada à indução de apoptose nas neoplasias de cólon (REDDY et al., 1997).

Da mesma forma, ração contendo $1 \%$ de esqualeno também foi capaz de inibir a indução e multiplicidade de FCAs em ratos F344 iniciados com azoximetano (RAO et al., 1998).

Também foi observada atividade quimiopreventiva por parte do farnesol em modelo de carcinogênese de cólon. Assim, ratos F-344 foram tratados com esse 
isoprenóide $(0,8 \mathrm{~g}$ e 1,6 g/100 g de ração) 1 semana antes da administração de azoximetano e 4 semanas após. Em ambas as concentrações na ração, o farnesol inibiu FCAs $\geq 4$ criptas (WARGOVICH et al., 2000).

Em estudo semelhante, a administração de farnesol a 1,5\% e lanosterol a 1\% na ração de ratos $F-344,1$ semana antes da iniciação da carcinogênese com azoximetano e 9 semanas após, resultou em redução da incidência e multiplicidade de FCAs (FCAs $\geq 4$ criptas) no cólon (RAO et al., 2002).

Além disso, foi verificado que pequenas doses de beta-caroteno (molécula da qual a beta-ionona é formada) e luteína inibiram a formação de FCAs em cólons de ratos F344 induzidos por azoximetano. Porém a formação dessas lesões aumentou quando as mesmas substâncias foram administradas em doses mais elevadas (RAJU et al., 2005).

Assim, diversos trabalhos demonstram a importância da análise de FCA para se estudar carcinógenos específicos para o cólon e moduladores do processo carcinogênico como os isoprenóides (BIRD; GOOD, 2000).

Diante dos vários trabalhos já citados demonstrando a ação anti-neoplásica de isoprenóides, alguns autores investigaram seus possíveis efeitos quando administrados em associação. He et al. (1997) avaliaram a ação da BI, um isoprenóide cíclico, associada ao gama-tocotrienol, um isoprenóide misto. Estas substâncias foram administradas nas doses de $2 \mathrm{mmol} / \mathrm{kg}$ de ração a camundongos após transplante com células B16 de melanoma e resultaram na supressão do crescimento neoplásico, evidenciando um efeito aditivo e potencialmente sinérgico desses isoprenóides quando associados. Em cultura de células, a associação entre esses dois isoprenóides - o gama-tocotrienol e a $\mathrm{BI}$ - demonstrou uma possivel ação 
Geraniol, mas não beta-ionona ou associaçăo desses isoprenóides, possui atividade quimiopreventiva em ratos submetidos a modelo de carcinogénese de cólon.

sinérgica dessas substâncias (HE et al.,1997; MO; ELSON 1999). Entretanto, a associação entre $\mathrm{BI}$ e carvacrol, dois isoprenóides cíclicos, quando administrados à cultura de células B16 de melanoma, demonstrou uma atividade supressora do crescimento inferior à esperada (He et al., 1997). Já Mo e Elson (1999) verificaram a possibilidade de uma ação sinérgica entre 2 isoprenóides acíclicos (um análogo do farnesol e um análogo do geraniol), em cultura de células de melanoma B16, obtendo um resultado também inferior ao esperado. Assim, estes autores sugeriram que uma associação entre isoprenóides somente cíclicos ou acíclicos não resulta em ação sinérgica, uma vez que, possivelmente, o membro menos potente da associação poderia estar atenuando a ação de supressão tumoral do membro mais potente (HE et al.,1997; MO; ELSON, 1999).

Nesse contexto, é importante destacar que não existem, até o momento, dados disponiveis na literatura em que se demonstrou in vivo a associação dos isoprenóides GO (acíclico) e Bl (cíclico) na carcinogênese, bem como a atuação destes durante as fases de iniciação e pós-iniciação de modelo de carcinogênese de cólon.

Com isso, os resultados do presente estudo revelam que o $\mathrm{GO}$, mas não $\mathrm{BI}$, é um agente quimiopreventivo na carcinogênese de cólon, pois este reduziu a formação de FCAs. Entretanto, ao avaliar a atividade protetora do geraniol e betaionona quando associados, não se observou uma atividade sinérgica ou aditiva, mas, eventualmente, uma possivel atenuação da atividade do membro mais potente por aquele menos potente (HE et al., 1997; MO; ELSON, 1999).

Diversos isoprenóides, tais como o farnesol (CORELL et al., 1994; MEIGS et al., 1997; ONG et al., 2005), GO (YU et al., 1994), tocotrienóis (PARKER et al., 
1993), beta-caroteno (MORENO et al., 1995), BI (ELSON, 1995, ESPINDOLA et al., 2005), limoneno (QURESHI et al., 1998), mentol (CLEGG et al., 1982) e geranilgeraniol (SEVER et al., 2003; ESPINDOLA et al., 2005) apresentam a capacidade de inibir in vitro e in vivo a enzima HMGCoA redutase por meio de mecanismos pós-transcricionais (ELSON et al., 1994; 1995), dentre os quais se destaca o estímulo da degradação da enzima (PARKER et al., 1993; ELSON et al., 1999). Em vários casos, a inibição da HMGCoA redutase resultou em reduções modestas dos níveis de colesterol plasmático total (CROWELL, 1999; ELSON et al., $1994 ; 1995 ; 1999)$.

GO e $\mathrm{BI}$, mais especificamente, inibem a atividade de HMGCoA redutase hepática (ELSON, 1995), reduzem o desenvolvimento de diversas linhagens celulares de câncer in vitro (CARNESECCHI et al., 2001; LIU et al., 2004) além de neoplasias mamárias em roedores (ELSON, 1995; YU et al; 1995).

No presente estudo, constatou-se menor concentração de colesterol plasmático total $(\mathrm{mg} / \mathrm{dl})$ nos ratos Wistar do grupo experimental $\mathrm{BI}(p \leq 0,05)$ em comparação ao grupo controle $\mathrm{OM}$, enquanto os tratamentos com GO e GO + BI não resultaram em qualquer efeito nesse sentido (Tabela 5).

Devido ao fato de estudos indicarem a $\mathrm{BI}$ como um potente inibidor da atividade da HMGCoA redutase (YU et al., 1994; YU et al., 1995; ELSON, 1999), a redução da concentração plasmática de colesterol pode ser consequência do impacto que esse isoprenóide apresenta na supressão dessa enzima (YU et al., 1994). Em um estudo com diferentes isoprenóides, houve pronunciada redução na concentração plasmática de colesterol total pelo tratamento com $\mathrm{BI}$, sendo que esta foi maior que a de d-limoneno e GO em modelo de carcinogênese mamária (YU et 
Geraniol, mas não beta-ionona ou associação desses isoprenóides, possui atividade quimiopreventiva em ratos submetidos a modelo de carcinogênese de cólon.

al., 1995). Isso indica que a diminuição da concentração de colesterol pode ser considerada uma medida indireta da redução da atividade de HMGCoA-redutase e conseqüente inibição da via do mevalonato (ESPINDOLA et al, 2005). Com isso, estaria limitada a disponibilidade de colesterol e dos isoprenóides intermediários dessa via, os quais são necessários para o processamento pós-traducional (prenilação) de proteínas relacionadas à proliferação celular e apoptose, importantes para a transformação neoplásica.

Por outro lado, no presente estudo, o tratamento com $\mathrm{BI}$ não reduziu o número de lesões pré-neoplásicas (FCAs) na mucosa colônica.

Sabendo-se que produtos intermediários do metabolismo do mevalonato parecem ser críticos para a proliferação de muitas células, inibidores de HMGCoA redutase (como estatinas) têm apresentado efeitos benéficos em diversas neoplasias, porém esse efeito parece ser independente da redução da concentração de colesterol plasmático total (MASSY et al., 1996). Talvez, por esse motivo, mesmo que o tratamento com $\mathrm{BI}$ tenha diminuído a atividade de HMGCoA-redutase e, assim, a concentração de colesterol plasmático total, ele não apresentou atividade quimiopreventiva, ou seja, não reduziu o número de FCAs. Ou, ainda, o tratamento com $\mathrm{BI}$ pode ter inibido somente HMGCoA-redutase hepática (já que o colesterol total foi medido no plasma) sem conseqüências para a carcinogênese de cólon especificamente.

Além disso, a inibição da biossíntese de colesterol também pode ter ocorrido na conversão de lanosterol a colesterol em uma etapa da via do mevalonato posterior à HMGCoA-redutase, ou seja, sem alterar a atividade da enzima (CROWELL, 1999; BURKE et al., 1997). 
Por outro lado, estudos indicam que a BI não inibiu a HMGCoA redutase, embora tenha reduzido a proliferação de células de câncer de mama MCF-7. Esses resultados sugerem que os efeitos inibitórios na proliferação celular por esse isoprenóide também podem ser independentes do metabolismo do mevalonato (DUNCAN et al., 2004).

Quanto à ação anticarcinogênica do GO, ela pode ser principalmente atribuida à inibição da atividade da enzima HMGCoA redutase, levando à limitação dos intermediários da via do mevalonato necessários ao processamento póstraducional de proteinas envolvidas na carcinogênese (CARNECECCHI et al., 2001; ELSON, 1995).

Entretanto, o tratamento com GO não resultou em redução da concentração plasmática de colesterol total em comparação ao grupo controle. Isto sugere que a inibição da formação de lesões pré-neoplásicas no cólon pelo tratamento com GO pode ser devida a mecanismos não relacionados com a via do mevalonato e com a inibição da atividade de HMGCoA-redutase (ONG et al., 2005), tais como a inibição da atividade da ornitina descarboxilase, enzima-chave na biossintese de poliamina, que está mais expressa na carcinogênese e também relacionada com a prenilação da proteína oncogênica Ras (CARNESECCHI et al., 2001).

Trabalhos anteriores realizados por nosso grupo podem confirmar essa hipótese. A administração de GO (25 mg/100g rato) durante 8 semanas nas fases de iniciação e promoção, também não modificou as concentrações plasmáticas de colesterol total, apesar de ter inibido a proliferação celular e induzido a apoptose em ratos submetidos a modelo de hepatocarcinogênese (ONG et al., 2005). Dessa forma, a atividade quimiopreventiva do GO não foi relacionada, nesse caso, à 
Geraniol, mas não beta-ionona ou associação desses isoprenóides, possui atividade quimiopreventiva em ratos submetidos a modelo de carcinogénese de cólon.

inibição de HMGCoA-redutase. Já a administração de $\mathrm{BI}$ na dose de $16 \mathrm{mg} / 100 \mathrm{~g}$ rato, nas mesmas fases da hepatocarcinogênese, diminuiu as concentrações plasmáticas de colesterol total, levando também à inibição da proliferação celular. Já nesse outro caso, a atividade quimiopreventiva da BI poderia estar relacionada à inibição da via do mevalonato pela redução da atividade enzimática de HMGCoAredutase (ESPÍNDOLA et al., 2005), fato que não ocorreu no presente trabalho.

Demonstrou-se, ainda, que o monoterpeno geraniol inibe a HMGCOA redutase por meio da modulação da estabilidade das moléculas de mRNA da HMGCoA redutase, ou seja, por mecanismos pós-transcricionais (PEFFLEY E GAYEN, 2003), de forma semelhante ao sugerido para o beta-caroteno, um isoprenóide cíclico com 40 carbonos (MORENO et al., 1995). Contudo, descreve-se que a capacidade do GO de inibir a HMGCoA redutase é menor do que a da betaionona (YU et al., 1995). Assim, embora se relate a inibição da atividade da HMGCoA redutase pelo geraniol em animais de experimentação (FITCH et al., 1989), com redução concomitante dos níveis de colesterol plasmático (YU et al., 1994), descreve-se, por outro lado, que em indivíduos hipercolesterolêmicos esse isoprenóide não apresentou, nesse sentido, qualquer impacto (Wahlqvist et al., 1992).

Além disso, em estudos envolvendo outros isoprenóides além do GO e BI, observou-se atividades quimiopreventivas por parte do farnesol, lanosterol e esqualeno, em modelo de carcinogênese de cólon experimental induzida por AOM, as quais não foram acompanhadas de redução das concentrações plasmáticas de colesterol total (RAO et al, 1998; 2002). 
Geraniol, mas não beta-ionona ou associação desses isoprenóides, possui atividade quimiopreventiva em ratos submetidos a modelo de carcinogénese de collon.

Assim, os resultados sugerem que, neste trabalho, o colesterol não foi o fator determinante para o desenvolvimento de lesões pré-neoplásicas, mas sim os derivados isoprênicos envolvidos com a prenilação de proteínas relacionadas à carcinogênese.

Para se avaliar outro possível modo de ação por parte dos isoprenóides decidiu-se por utilizar o método do "cometa", no contexto experimental em questão, para verificar se a atividade quimiopreventiva por parte do geraniol poderia estar eventualmente relacionada a uma inibição de danos no DNA.

Desde que o dano no DNA foi reconhecido como evento inicial da carcinogênese, o seu bloqueio poderia ser uma resposta de defesa contra o desenvolvimento de neoplasias causadas por carcinógenos. Acredita-se que mecanismos pelos quais certas substâncias químicas podem causar a carcinogênese sejam mediados por radicais livres. DMH pode produzir espécies reativas de oxigênio (ERO), induzir danos no DNA e desenvolvimento de neoplasias, sendo que essas alterações podem ser evitadas pela neutralização de radicais livres. Com isso, há evidências indiretas do envolvimento desses radicais livres na carcinogênese de cólon (RAJESHKUMAR; KUTTAN, 2003; SENGOTTUVELAN et al., 2006). Dessa forma, por serem capazes de danificar biomoléculas como o DNA, EROs podem causar mutações em genes como os supressores de tumor e/ou protooncogenes e, dessa forma, estimular a formação de neoplasias (SHEN; ONG, 1996).

O teste do "Cometa" pode ser usado para se avaliar danos no DNA em órgãos individuais de roedores expostos a carcinógenos. Essa análise é baseada na capacidade de fragmentos de DNA desnaturados migrarem de seus núcleos formando caudas de cometas durante a eletroforese, em condições alcalinas 
Geraniol, mas não beta-ionona ou associação desses isoprenóides, possui atividade quimiopreventiva em ratos submetidos a modelo de carcinogénese de cólon.

$(\mathrm{pH}=12,6)$, e tem sido usada para examinar a eficácia de agentes quimiopreventivos nos estágios iniciais da carcinogênese (NOZAWA et al., 2004).

Nesse estudo, os cometas (Figura 13) foram corados com nitrato de prata devido a vantagens como: obter o registro permanente das lâminas, evitar problemas relacionados à fluorescência (como o seu decaimento) e a possibilidade de utilização de um simples microscópio de luz (TOLEDO et al., 2003; ONG et al., 2005; ESPÍNDOLA et al., 2005).

Foi possivel se constatar que os comprimentos dos "cometas" observados no grupo controle óleo de milho foram maiores do que os observados no grupo não submetido a qualquer tratamento (Tabela 6). Nesse sentido, esses dados sugerem que a ocorrência de danos no DNA representa evento precoce na carcinogênese de cólon. Além disso, tanto a iniciação como a pós-iniciação caracterizam-se por um estado oxidativo com grande potencial de ser modulado por agentes quimiopreventivos contra o câncer (NAKAE et al., 1997). Assim, foram observados nos tratamentos com GO, $\mathrm{BI}$ e $\mathrm{GO}+\mathrm{BI}$ "cometas" de menor comprimento em comparação ao grupo controle, indicando que os danos no DNA da mucosa colônica foram significativamente reduzidos pela administração destes isoprenóides.

O teste do "Cometa" alcalino possibilita a avaliação de quebras nas fitas simples e a formação de sítios álcali lábeis no DNA que serão convertidos em quebras durante a eletroforese alcalina (COLLINS, 2004). O dano no DNA foi iribido por todos os tratamentos realizados nesse estudo, $\mathrm{GO}, \mathrm{Bl}$ e $\mathrm{GO}+\mathrm{BI}$. Isso pode sugerir que a inibição dos danos no DNA por esses compostos poderia envolver propriedades antioxidantes, indução do sistema de reparo de DNA, inibição da 
Geraniol, mas não beta-ionona ou associação desses isoprenóides, possui atividade quimiopreventiva em ratos submetidos a modelo de carcinogénese de cólon.

formação de adutos no DNA ou, simplesmente, ser um reflexo de uma inibição do processo carcinogênico (ESPINDOLA et al., 2005, ONG et al., 2005).

Compostos químicos com propriedades antioxidantes possuem a capacidade de inibir a carcinogênese de cólon induzida por DMH ou AOM e danos no DNA em modelos com animais de experimentação (LIMA et al, 2005) e têm sido muito utilizados em estudos de quimiopreveção do câncer (SENGOTTUVELAN et al., 2006). O exato mecanismo de ação desses compostos ainda não foi totalmente elucidado, mas existem sugestões de que eles possam eliminar metabólitos de carcinógenos e alterar o sistema enzimático responsável pela ativação de procarcinógenos (TANAKA; MORI et al., 1996), no caso do presente estudo, diminuindo a carcinogenicidade da DMH.

Com isso, de acordo com Hierro et al., 2004, a inibição da ocorrência de danos no DNA pelo GO poderia estar eventualmente relacionada à sua capacidade antioxidante. In vitro, o monoterpeno apresentou ações antioxidantes mais potentes quando comparado a outros isoprenóides presentes em óleos essenciais de frutas cítricas, tais como o limoneno, citral e citronelol. Nesse caso, descreveu-se que o GO exerceu suas ações seqüestrando radicais livres (CHOI et al., 2000). Da mesma forma He et al. indicaram que a BI possui estrutura química semelhante a compostos com propriedades antioxidantes. Além disso, Bl é uma das moléculas formadas em maiores proporções a partir da clivagem do beta-caroteno (MO; ELSON, 1999; SIMKIN et al., 2004), uma molécula com atividade antioxidante ponunciada (RAJU et al., 2005). Assim, Bl poderia ter exercido seu efeito na diminuição de danos no DNA também através da neutralização de EROs. Portanto, embora essa atividade antioxidante por parte do GO e BI, no presente trabalho, seja apenas sugestiva e 
Geraniol, mas não beta-ionona ou associação desses isoprenóides, possui atividade quimiopreventiva em ratos submetidos a modelo de carcinogênese de cólon.

não totalmente conclusiva, mais estudos seriam necessários para esclarecer os exatos efeitos dessas substâncias na redução de danos no DNA, como por exemplo, o uso de endonucleases, enzimas que reconhecem um tipo particular de dano e que cliva o DNA em regiōes com lesões específicas contendo bases nitrogenadas oxidadas (COLLINS, 2004).

Além disso, GO e BI poderiam também ter eventualmente inibido os danos no DNA via indução de seu reparo, conforme descrito por outros agentes quimiopreventivos, como a epigalocatequina (ESPINDOLA et al, 2005; GLEI; POOLZOBEL, 2006) já que enzimas de reparo são susceptiveis à inibição por espécies reativas de oxigênio e que a diminuição de radicais livres através da exposição a agentes antioxidantes resultaria em maiores índices de reparo (GLEl; POOL-ZOBEL, 2006). Os isoprenóides poderiam também ter atuado na atividade de enzimas destoxificantes (como a glutationa-S-transferase por exemplo), as quais possuem atividades anticarcinogênicas inibindo tanto o estágio de iniciação quanto o estágio de promoção da carcinogênese (MANJU; NALINI et al, 2005).

De qualquer forma, os dados observados em relação ao método do "cometa" demonstram que os isoprenóides foram capazes de reduzir os danos no DNA em modelo de carcinogênese de cólon. Por outro lado, essa redução pelo tratamento com $\mathrm{BI}$ e $\mathrm{GO}+\mathrm{Bl}$ talvez não tenha sido suficiente para a inibição da formação de FCAs.

Outro mecanismo estabelecido de desenvolvimento de neoplasias no cólon é o desequilibrio entre a proliferação celular e apoptose que resulta na alteração da homeostase e da cinética normal das células do epitélio colônico conduzindo a um crescimento epitelial descontrolado e progressão neoplásica (BUTLER et al., 1999). 
Poucos estudos in vitro estudaram a capacidade de modulação da apoptose pelos isoprenóides GO e BI. Duncan et al. (2004) não observaram atividade proapoptótica por parte do GO e da BI em células MCF-7 de carcinoma de mama. Por outro lado, o GO foi capaz de induzir a apoptose em células de carcinoma de pâncreas (BURKE et al., 2002) e a Bl em células SGC-7901 de adenocarcinoma gástrico (LIU et al., 2004a), células B16 de melanoma e HL-60 de leucemia (MO; ELSON, 1999). Convém ressaltar que não foram encontrados na literatura estudos avaliando a modulação da morte celular pela associação dos isoprenóides GO e BI. De forma semelhante ao presente estudo, em trabalho prévio de nosso grupo, constatou-se uma indução da apoptose em LPN quando o GO foi administrado continuamente durante as fases de iniciação e promoção da hepatocarcinogênese no modelo do RH (ONG et al., 2005). A partir disso, tornou-se interessante avaliar se GO, BI ou GO+BI teriam alguma ação nesse sentido.

Proteínas da familia Bcl-2, composta por membros pró e anti-apoptóticos, são importantes por regularem a via intrínseca da apoptose. Nesse contexto, estudos vêm demonstrando grande aumento de expressão de Bcl-2 (um membro antiapoptótico dessa família) em adenomas colônicos. Isso demonstra que a expressão de $B c /-2$ já está alterada em fases precoces da seqüência adenoma-carcinoma da carcinogênese de cólon (HUERTA et al., 2006). Assim, a maior expressão de Bcl-2 em lesões pré-neoplásicas é considerada evento inicial na transformação maligna nesse órgão. Isso facilita a sobrevivência de células anormais à medida que estas não são mais controladas pelo mecanismo regulatório da morte celular programada e, dessa forma, favorece o acúmulo de mutações genéticas adicionais observadas em adenocarcinomas colônicos (NAKAMURA et al., 1996). 
Geraniol, mas năo beta-ionona ou associaçăo desses isoprenóides, possui atividade quimiopreventiva em ratos submetidos a modelo de carcinogénese de cólon.

A expressão de $B c l-2$ diminui à medida que as células normais do epitélio do cólon migram ao longo da cripta. Assim, há maior expressão de $B c l-2$ na base das criptas do cólon, sendo que mínimas quantidades são encontradas no topo da cripta. Isso indica que essa proteína inibe a morte celular programada para que as células da base da cripta continuem a se dividir. A falta de capacidade de essas células sofrerem apoptose quando algum estresse genotóxico está presente acabaria aumentando a susceptibilidade destas à transformação maligna (HUERTA et al., 2006).

Sabe-se que compostos bioativos presentes em frutas e hortaliças diminuem a expressão de $\mathrm{Bcl}-2$ em células humanas de câncer de cólon (HT-29), aumentando o indice de apoptose (RAJU et al., 2004; SONG et al., 2005, VOLATE et al, 2005).

Em trabalhos prévios com isoprenóides e membros da familia de proteínas Bcl-2, foi observada indução da proteína pró-apoptótica Bak com a administração de álcool perilílico em cultura de células pancreáticas malignas (BxPC3) (STAYROOK, et al., 1997). Posteriormente, verificou-se que animais tratados com dietas contendo farnesol e álcool perilílico apresentaram maior expressão de Bak e menor expressão de Bcl-xl (membro anti-apoptótico da família Bcl-2) (BURKE et al., 2002).

Tratamento com geranilgeraniol, composto derivado da via do mevalonato, e células de hepatoma humano (HuH-7) diminuiu a expressão de $B c l-x l$. Por outro lado, essas células não expressaram $B c /-2$ e não mostraram diferenças na expressão de Bak no tratamento com esse isoprenóide (TAKEDA et al., 2001).

Sabe-se também que inibidores de HMGCoA-redutase, como a lovastatina, induzem apoptose em células de câncer de cólon por inibição de isoprenilação de proteínas envolvidas com transduções de sinais relacionados à proliferação celular, 
diferenciação e morte celular (AGARWAL, 1999; KANEKO, 2007). Dessa forma, tratamento com lovastatina resultou em diminuição da expressão de $B c l-2$ e aumentou a expressão de Bax (pró-apoptótico) em linhagens celulares de câncer de cólon. Essas alterações podem explicar o aumento da susceptibilidade dessas células à apoptose (AGARWAL, 1999).

Dessa forma, detectou-se a expressão de $\mathrm{Bcl}-2$, em nivel de proteína, em ratos sem tratamento ou tratados com $\mathrm{OM}, \mathrm{BI}, \mathrm{GO}$ ou $\mathrm{BI}+\mathrm{GO}$ durante as fases de iniciação e pós-iniciação de modelo de carcinogênese de cólon. Observou-se redução na expressão colônica de $\mathrm{Bcl}-2$ no grupo tratado com GO quando comparados ao grupo controle OM. Com isso, o tratamento com geraniol pode ter reduzido a formação de lesões pré-neoplásicas no cólon nesses animais por meio da indução de apoptose.

Assim, no presente estudo, constatou-se que o tratamento com GO apresentou atividade quimiopreventiva continuamente durante as etapas de iniciação e pós-iniciação de modelo de carcinogênese de cólon induzida por DMH inibindo a formação de lesões pré-neoplásicas em cólon de ratos tratados com esse isoprenóide.

De uma forma geral, a partir de dados da literatura e dos resultados obtidos neste trabalho, podemos notar que a determinação da relevância na alimentação e da ação protetora dos isoprenóides requer estimativas de sua ingestão, expansão da lista dos isoprenóides promissores e uma confirmação de que eles tenham efeitos aditivos. De qualquer maneira, uma alimentação com alto consumo de frutas e hortaliças (onde está a maior fonte de isoprenóides) é fundamental para a diminuição do risco de desenvolvimento de câncer (TATMAN; MO, 2002). 
Geraniol, mas não beta-ionona ou associaçăo desses isoprenóides, possui atividade quimiopreventiva em ratos submetidos a modelo de carcinogénese de cólon.

\section{VI- Conclusões:}

- A administração de $\mathrm{GO}$, mas não de $\mathrm{BI}$, durante as etapas de iniciação e pós-iniciação de modelo de carcinogênese de cólon induzida por DMH resultou em atividade quimiopreventiva por meio da redução da formação de Focos de Criptas Aberrantes, considerados lesões pré-neoplásicas nesse modelo de carcinogênese.

- A associação de GO e BI não resultou em atividade aditiva ou sinérgica na quimioprevenção da carcinogênese de cólon não apresentando qualquer efeito na redução de FCAs.

- Tratamento com BI diminuiu a concentração plasmática de colesterol total.

- Tratamentos com $\mathrm{GO}, \mathrm{BI}$ ou $\mathrm{GO}+\mathrm{BI}$ reduziram os danos no DNA.

- Tratamentos com GO e GO+BI reduziram a expressão de $B c l-2$ em mucosas colônicas, embora os resultados não tenham atingido diferença estatisticamente significante. 


\section{VII- Referências Bibliográficas:}

AGARWAL, B., BHENDWAL, S., HALMOS, B., MOSS, S. F, RAMEY, W. G, HOLT, $P$. R. Lovastatin augments apoptosis induced by chemotherapeutic agents in colon cancer cells. Clin Cancer Res. v. 5(8), p. 2223-9, 1999.

AGGARWAL, B. B., SHISHODIA, S. Molecular targets of dietary agents for prevention and therapy of cancer. Biochem Pharmacol. v. 71(10), p.1397-421. 2006.

BANERJEE, A., QUIRKE, P. Experimental models of colorectal. Dis. Colon Rectum, Philadelphia, v. 41, p. 490-505, 1998.

BARKOVICH R. AND LIAO J. C. Metabolic Engineering of Isoprenoids. Metabolic Engineering. v. 3, p. 27-39, 2001.

BARTH, S. W., FAHNDRICH, C., BUB A., DIETRICH H., WATZL B., WILL F., BRIVIBA K., RECHKEMMER G. Cloudy apple juice decreases DNA damage, hyperproliferation and aberrant crypt foci development in the distal colon of DMHinitiated rats. Carcinogenesis, v.26 no.8 pp.1414--1421, 2005.

BAZO A. P., MARCHESAN M. A., SFORCIN J. M., VIANA J. L., RIBEIRO L. R., SALVADORI D. M. F., Protective action of propolis on the rat colon carcinogenesis. Teratogenesis, Carcinogenesis, Mutagenesis, v.22, p.183-194, 2002.

BIRD, R.P. Observation and quantification of aberrants cryptas in the murine colon treated with a colon carcinogenesis: preliminary findings. Cancer Lett., v. 37, p.147$51,1987$.

BIRD, R. P. Role of aberrant crypt foci in understanding the pathogenesis of colon cancer. Cancer Lett., v. 51, p. 55-71, 1995

BIRD R. P., SALO D., LASKO C., GOOD C. A novel methodological approach to study the level of specific protein and gene expression in aberrant crypt foci putative preneoplastic colonic lesions by Western blotting and RT-PCR. Cancer Lett., v.116, p.15-19, 1997. 
Geraniol, mas nāo beta-ionona ou associação desses isoprenóides, possui atividade quimiopreventiva em ratos submetidos a modelo de carcinogênese de cólon.

BIRD R. P., GOOD C. K. The significance of aberrant crypt foci in understanding the pathogenesis of colon cancer. Toxicol. Lett. v.112-113, p. 395-402, 2000.

BLAKEY D. H., DUNCAN A. M. V., WARGOVICH M. J., GOLDBERG M., BRUCE T. W. R., AND J. A. HEDDLE. Detection of Nuclear Anomalies in the Colonie Epithelium of the Mouse. Cancer Res. v. 45, p. 242-249, 1985.

BURKE, Y. D., STARK, M. J., ROACH, S. L., SEM, S. E., CROWELL, P. L. Inhibition of pancreatic cancer growth by the dietary isoprenoids farnesol and geraniol. Lipids, v. 32, p. 151-156, 1997.

BURKE, Y. D., AYOUBI, A. S., WERNER, S. R., MCFARLAND, B. C., HEILMAN, D. K., RUGGERI, B. A., CROWELL, P. L. Effects of the isoprenoids perillyl alcohol and farnesol on apoptosis biomarkers in pancreatic cancer chemoprevention. Anticancer Res., v. 22, p. 3127-3134, 2002.

BUTLER, L. M., HEWETT, P. J, FITRIDGE, R. A., COWLED, P. A. Deregulation of apoptosis in colorectal carcinoma: theoretical and therapeutic implications. Aust. N. Z. J. Surg. v. 69(2), p. 88-94, 1999.

CADERNI, G., FEMIA, A.P., GIANNINI, A., FAVUZZA, A., LUCERI, C., SALVADORI, M., DOLARA, P. Identification of mucin-depleted foci in the unsectioned colon of azoxymethane-treated rats: correlation with carcinogenesis. Cancer Res. v.63(10), p. 2388-92, 2003.

CAMERON. I. L.. GARZA. J., AND HARDMAN. W. E. Distribution of lymphoid nodules, aberrant crypt foci and tumours in the colon of carcinogen-treated rats. Br. J. Cancer. v. 73, p. 893-898, 1996.

CARNESECCHI, S., SCHNEIDER, Y., CERALINE, J., DURANTON, B., GOSSE, F., et al. Geraniol, a component of plant essential oils, inhibits growth and polyamine biosynthesis in human colon cancer. J. Pharmacol. Exp. Ther., v. 298, p. 197-200, 2001.

CARNESECCHI, S., BRAS-GONÇALVES, R., BRADAIA, A., ZEISEL, M., GOSSÉ, F., POUPON M-F., RAUL, F. Geraniol, a component of plant essential oils, modulate DNA synthesis and potentiates 5-fluorouracil efficacy on human colon tumor xenografts. Cancer Lett. v. 215, p.53-59, 2004. 
CHANG, W-C. L., CHAPKIN, R. S., LUPTON, J. R. Predictive value of proliferation, differentiation and apoptosis as intermediate markers for colon tumorigenesis. Carcinogenesis. v. $18\left(n^{\circ} 4\right)$, p. 721-730, 1997.

CHENG, L., LAI, M. D. Aberrant crypt foci as microscopic precursors of colorectal cancer. World J Gastroenterol. v. 9(12), p. 2642-9, 2003.

CHOI, H. S., SONG, H. S., UKEDA, H., SAWAMURA, M. Radical-scavenging activities of citrus essential oils and their components: detection using 1,1-diphenyl-2picrylhydrazyl. J. Agric. Food Chem., v. 48, p. 4156-4161, 2000.

CLEGG, R. J.; MIDDLETON, B.; BELL, G. D., WHITE, D. A. The mechanisms of cyclic monoterpene inhibition of 3-hydroxi-3methylglutaryl coenzyme A reductase in vivo in the rat. J. Biol. Chem., v. 257, p.2294-99, 1982.

COLLINS, A.R. The Comet Assay for DNA Damage and Repair. Molec. Biotechnology. v. 26, p. 249-261, 2004.

COOPER H. K., BUECHELER J., AND KLEIHUES P. DNA Alkylation in Mice with Genetically Different Susceptibility to 1,2-Dimethylhydrazine-induced Colon Carcinogenesis. Cancer Res. v. 38, p. 3063-3065, 1978.

CORPET, D. E, PIERRE, F. How good are rodent models of carcinogenesis in predicting efficacy in humans? A systematic review and meta-analysis of colon chemoprevention in rats, mice and men. Eur J Cancer. v. 41(13), p.1911-22, 2005

CORRELL, C. C., NG, L., EDWARDS, P. A. Identification of farnesol as the nonsterol derivative of mevalonic acid required for the accelerated degradation of 3-hydroxi-3methylglutaryl-coenzyme A reductase. J. Biol. Chem., v. 269, p. 17390-17393, 1994

CROWELL, P. L. Prevention and therapy of cancer by dietary monoterpenes. J. Nutr., v.129, p.775S-78S, 1999.

DAVIS, C.D.; MILNER, J. Frontiers in nutrigenomics, proteomics, metabolomics and cancer prevention. Mutat. Res., v. 551, n.1-2, p.51-64, 2004. 
DAVIDSON, L. A, BROWN, R. E., CHANG W-C. L., MORRIS, J. S., WANG, N., CARROL, R. J., TURNER, N. D., LUPTON, J. R., CHAPKIN, R. S. Morphodensitometric analysis of protein kinase $\mathrm{C}$ Bll expression in rat colon: modulation by diet and relation to in situ cell proliferation and apoptosis. Carcinogenesis, v. 21, (8), p. 1513-1519, 2000.

DE FLORA S.; FERGUSON, L.R. Overview of mechanisms of cancer chemopreventive agents. Mutat. Res., v. 591, n.1, 2, p.8-15, 2005.

DIAS M.C., SPINARDI-BARBISAN, A. L. T., RODRIGUES, M. A. M., DE CAMARGO, J. L. V., TERA'N, E., BARBISAN, L.F. Lack of chemopreventive effects of ginger on colon carcinogenesis induced by 1,2-dimethylhydrazine in rats. Food Chem. Toxicol. v. 44, p. 877-884, 2006.

DIPPLE, A. DNA adducts of chemical carcinogenesis. Carcinogenesis, v. 16, p.437$441,1995$.

DOLL, R. Symposium on "Diet and cancer". Proc. Nutr. Soc., v. 49, p.119-131, 1990.

DOLL, R. The lessons of life: Keynote address of the nutrition and cancer conference. Cancer Res., v. 52, p.2024s-2029s, 1992.

DUNCAN, R. E., LAU, D., EL-SOHEMY, A., ARCHER, M. C. Geraniol and $\beta$-ionona inhibit proliferation, cell cycle progression, and cyclin-dependent kinase 2 activity in MCF-7 breast cancer cells independent of effects on HMG-CoA reductase activity. Biochem. Pharmacol. v. 68, p. 1739-1747, 2004.

ELSON, C. E., MALTZMAN, T. H., BOSTON, J. L., TANNER, M. A., GOULD, M. N. Anti-carcinogenic activity of d-limonene during the initiation and promotion/progression stages of DMBA-induced rat mammary carcinogenesis. Carcinogenesis, v. 9, p.331-332, 1988.

ELSON, C. E.; YU, S. G. The chemoprevention of cancer by mevalonate-derived constituents of fruits and vegetables. J. Nutr., v.124, p. 607-14, 1994. 
ELSON, C. E. Supression of mevalonate pathway activities by dietary isoprenoids: Protective roles in cancer and cardiovascular disease. J. Nutr., v. 125, p. 1666s-72s, 1995.

ELSON, C. E., PEFFlEY, D. M., HENTOSH, P., MO, H. Isoprenoid-mediated inhibition of mevalonate synthesis: Potential application to cancer. Proc. Soc. Exp. Biol. Med., v. 221, p.294-311, 1999.

ESPINDOLA, R. D., MAZZANTINI, R. P., ONG, T. P., CONTI, A D., HEIDOR, R., MORENO, F. S. Geranylgeraniol and beta-ionone inhibit hepatic preneoplastic lesions, cell proliferation, total plasma cholesterol and DNA damage during the initial phases of hepatocarcinogenesis, but only the former inhibits NF-kappaB activation. Carcinogenesis, 2005.

FARBER, E.; SARMA, D.S.R. Hepatocarcinogenesis: a dinamic cellular perspective. Lab. Invest., v.56(1), p.4-22, 1987.

FEARON, E. R., VOGELSTEIN, B. A genetical model for colorectal tumorigenesis. Cell, v. 61. p. 759-767, 1990.

FITCH, M. E.; MANGELS, A. R.; ALTMANN, W. A.; EL HAWRY, M.; QURESHI, A. A.; ELSON, C. E. Microbiological screening of mevalonate-supressive minor plant constituents. J. Agric. Food. Chem., v.37, p.687-91, 1989.

FORMAN, M.R.; HURSTING, S.D.; UMAR, A.; BARRETT, J.C. Nutrition and cancer prevention: A multidisciplinary perspective on human trials. Annu. Rev. Nutr., v.24, p.223-254, 2004.

FUHRMAN, B.; ELIS, A.; AVIRAM, M. Hypocholesterolemic effect of lycopene and $\beta$ carotene is related to supression of cholesterol synthesis and augmentation of LDL receptor activity in macrophages. Biochem. Biophys. Res. Commun., v. 233, p.658-662, 1997.

FRIEDBERG, E.C. DNA damage and repair. Nature, v. 421, p.436-440, 2003.

GERVAZ, P., BUCHER, P., MOREL, P. Two Colons-Two Cancers: Paradigm Shift and Clinical Implications. J. Surg.Oncol. v. 88, p. 261-266, 2004. 
GILL, C. I., ROWLAND, I. R. Diet and cancer: assessing the risk. Br. J. Nutr. v. 88 , p. $573-87,2002$.

GLEI, M., POOL-ZOBEL, B. L. The main catechin of green tea, $($-epigallocatechin3-gallate (EGCG), reduces bleomycin-induced DNA damage in human leucocytes. Toxicol. in Vitro. v. 20, p. 295-300, 2006.

GOLDSTEIN, J. L.; BROWN, M.S. Regulation of the mevalonate pathway. Nature, v. 343, p.425-30, 1990.

GUSTIN D. M., BRENNER D. E. Chemoprevention of colon cancer: Current status and future prospects. Cancer Metastasis Rev., v. 21, p. 323-348, 2002.

HANAHAN, D.; WEINBERG, R.A. The hallmarks of cancer. Cell, v.100, p.57-70, 2000.

HE, L.,MO, H., HADISUSILO, S., QURESHI, A. A., ELSON C. E. Isoprenoids supress the growth of murine B16 melanomas in vitro and in vivo. J. Nutr., v.127, p.668-674, 1997.

HEMMINKI, K. DNA adducts, mutations and cancer. Carcinogenesis, v. 14 (10):2007-12, 1993.

HIERRO, I., VAlERO, A., PEREZ, P., GONZALEZ, P., CABO, M. M., MONTILLA, M. P., NAVARRO, M. C. Action of different monoterpenic compounds against Anisakis simplex L3 larvae. Phytomedicine, v. 11, p. 77-82, 2004

HUERTA, S. M. D., GOULET, B.S.E.J., LIVINGSTON, E.H. M.D., F.A.C.S. Colon cancer and apoptosis. Am. J. Surg.. v.191 p. 517-526, 2006.

IACOPETTA, B. Are There Two Sides To Colorectal Cancer? Int. J. Cancer. v. 101, p. $403-408,2002$

JOHNSON, I. T. Anticarcinogenic effects of diet-related apoptosis in the colorectal mucosa. Food Chem. Toxicol., v. 40, p. 1171-1178, 2002. 


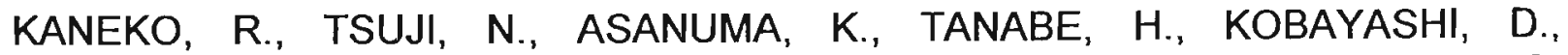
WATANABE, N. Survivin down-regulation plays a crucial role in 3-hydroxy-3methylglutaryl coenzyme $A$ reductase inhibitor-induced apoptosis in cancer. $J$ Biol Chem. v. 282(27), p.19273-81, 2007

KIZZILIAN, N., WILKINS, R. C., REINHARDT, P., FERRAROTTO, C., MCLEAN, J. R. N., et al. Silver-stained comet assay for detection of apoptosis. Biotechniques, v. 27, p. 926-930, 1999.

KLAUNIG, J. E., KAMENDULIS, L. M., XU, Y. Epigenetic mechanisms of chemical carcinogenesis. Hum. Exp. Toxicol., v. 19, p. 543-555, 2000.

KLIGERMAN, J. Estimativas sobre a incidência e mortalidade por câncer no Brasil 2002. Rev. Bra. Cancerologia, v.48, p.175-179, 2002.

KOB-EK-LARSEN, M., CHRISTENSEN, L., P., VACH, W., RITSKES-HORTIGA, J., BRANDT, K., Inhibitory effects of feeding with carrots or (-) falcorinol on development of azoximethane-induced preneoplastic lesions in the rat colon. J. Agric. Food Chem, p. 1823-1827, 2005.

LEE, B. M.; PARK, K. K. Beneficial and adverse effects of chemopreventive agents. Mutation Res., v. 523, p.265-278, 2003.

LIMA, R. O A, BAZO A P., SAID, R. A, SFORCIN, J. M., BANKOVA, V., DARROS, B. R., SALVADORI, D. M. F., Modifying effect of propolis on dimethyllhydrazineinduced DNA damage but no colonic aberrant crypt foci in rats., Environ. Mol. Mutagen. v. 45(1), p. 8-16, 2005.

LIU, J. R., CHEN, B. Q., YANG, B. F., DONG, H. W., SUN, C. H., WANG, Q., SONG, G., SONG, Y. Q. Apoptosis of human gastric adenocarcinoma cells induced by $\beta$ ionone. World J. Gastroenterol., v. 10, p.348-351, 2004.

LOEB, L. A., LOEB, K. R., ANDERSON, J. P. Multiple mutations and cancer. Proc. Nat. Acad. Sci., v. 100, p. 776-781, 2003. 

submetidos a modelo de carcinogénese de cólon.

LOTA, M-L., DE ROCCA SERRA, D., TOMI, F. L., JACQUEMOND, C., CASANOVA, J. Volatile components of peel and leaf oils of lemon and lime species. J. Agric. Food Chem., v. 50, p. 796-805, 2002.

MA Q-Y., WILLIAMSON K. E., ROWLANDS B. J. Variability of cell proliferation in the proximal and distal colon of normal rats and rats with dimethylhydrazine induced carcinogenesis. World J. Gastroenterol, v. 8, p. 847-852, 2002.

MANJU, V., NALINI, N. Chemopreventive efficacy of ginger, a naturally occurring anticarcinogen during the initiation, post-initiation stages of 1,2 dimethylhydrazineinduced colon cancer. Clinica Chimica Acta. v. 358, p. 60-67, 2005.

MASKENS A. P. Histogenesis and Growth Pattern of 1,2-Dimethylhydrazine induced Rat Colon Adenocarcinoma. Cancer Res. v. 36, p. 1585-1592, 1976.

MASSY, Z. A., KEANE, W. F., KASISKE, B. L. Inhibition of the mevalonate pathway: benefits beyond cholesterol reduction? Lancet. v. 347, p. 102-103, 1996.

MATHERS, J. C. The biological revolution - towards a mechanistic understanding of the impact of diet on cancer risk. Mutation Res. v. 551 p. 43-49, 2004.

MATHEW A., PETERS U., CHATTERJEE N., KULLDORFF M., and SINHA R. Fat, fiber, fruits, vegetables, and risk of colorectal adenomas. Int. J. Cancer, v. 108, p. 287-292, 2004.

MAURIN, N., FORGUE-LAFITTE, M.E., LEVY, P., ZIMBER, A., BARA, J. Progression of tumors arising from large ACF is associated with the MUC5AC expression during rat colon MNNG carcinogenis. Int. J. Cancer. v. 120, p. 477-483 2006.

MCLLELLAN, E A., MEDLINE A., BIRD R. P. Sequential analyses of the growth and morphological characteristics of aberrant crypt foci: putative preneoplastic lesions. Cancer Res., v. 51, p. 5270, 1991.

MEIGS, T. E., SIMONI, R. D. Farnesol as a regulator of HMG-CoA reductase degradation: Characterization and role of farnesyl pyrophosphatase. Arch. Biochem. Biophys., v. 345, p.1-9, 1997. 
Geraniol, mas năo beta-ionona ou associação desses isoprenóides, possui atividade quimiopreventiva em ratos submetidos a modelo de carcinogénese de cólon.

MINISTÉRIO DA SAÚDE. INSTITUTO NACIONAL DO CÂNCER - INCA. Estimativas da incidência e mortalidade por câncer. INCA, Rio de Janeiro, 2006, 92p.

MO, H., ELSON, C. E. Apoptosis and cell-cycle arrest in human and murine tumor cells are initiated by isoprenoids. J. Nutr., v. 129, p. 804-813, 1999.

MO, H., ELSON C. E. Studies of the isoprenoid-mediated inhibition of mevalonate synthesis applied to cancer chemotherapy and chemoprevention. Exp. Biol. Med. v. 229(7), p. 567-85, 2004.

MORENO, F. S., RIZZI, M. B. S. L., DAGLI, M. L. Z., PENTEADO, M. V .C. Inhibitory effects of beta-carotene on preneoplastic lesions induced in Wistar rats by the resistant hepatocyte model. Carcinogenesis, v. 12, p. 817-822, 1991.

MORENO, F. S., ROSSIELO, M. R., MANJESHWAR, S., NATH, R., RAO, P. M., RAJALAKSHMI S., SARMA, D. S. R. Effect of $\beta$-caroteno on the expression of 3hydroxi-3-mehyglutaryl coenzyme A reductase in rat liver. Cancer Lett., v. 96, p. 201-208, 1995.

NAKAE, D., KOBAYASHI, Y., AKAI, H., ANDOH, N., SATOH, H., OHASHI, K., TSUTSUMI, M., KONISHI, Y. Involvement of 8-hydroxyguanine formation in the initiation of rat liver carcinogenesis by low dose levels of $\mathrm{N}$-nitrosodiethylamine. Cancer Res., v. 57, p. 1281-1287, 1997.

NAKAMURA, T., NOMURA, S., SAKAI, T., NARIYA, S. Expression of bcl-2 Oncoprotein in Gastrointestinal and Uterine Carcinomas and Their Premalignant Lesions. Human Pathol. v. 28(3), p. 309-315, 1997.

NEWELL, L. E., HEDDLE J. A. The potent colon carcinogen, 1,2-dimethylhydrazine induces mutations primarily in the colon. Mutation Res., v. 564, p. 1-7, 2004.

NOZAWA, H., YOSHIDA, A., TAJIMA, O., KATAYAMA, M., SONOBE, $H_{\text {., }}$ WAKABAYASHI, $K$. and KONDO, K. Intake of beer inhibits azoxymethane-induced colonic carcinogenesis in male fischer 344 rats. Int. J. Cancer v. 108, p. 404-411, 2004. 
OMS. Programas Nacionales de lucha contra el cáncer: directrices sobre política y géstion. Ginebra; 1995.

OMS. Global strategy on diet, physical activity and health. WHO, 2004.

OHIZUMI, H., MASUDA, Y., NAKAJO, S., SAKAI, I., OHSAWA, S., NAKAYA, K. Geranylgeraniol is a potent inducer of apoptosis in tumor cells. J. Biochem., v. 117, p. 11-13, 1995.

ONG, T.P.; HEIDOR, R.; DE CONTI, A.; DAGLI, M.L.Z.; MORENO, F.S. Farnesol and geraniol chemopreventive activities during the initial phases of hepatocarcinogenesis involve similar actions on cell proliferation and DNA damage, but distinct actions on apoptosis, plasma cholesterol and HMGCoA reductase. Carcinogenesis, v.27(6), p.1194-1203, 2006.

PARKER, R. A., PEARCE, B. C., CLARK, R. W., GORDAN, D. A., WRIGHT, J. J. K. Tocotrienols regulate cholesterol production in mammalian cells by posttranscriptional suppression of 3-hydroxi-3-methylglutaryl-coenzyme A reductase. J. Biol. Chem., v. 268, p. 11230-11238, 1993.

PARK, H. S., GOODLAD, R. A., WRIGHT, N. A. The Incidence of Aberrant Crypt Foci and Colonie Carcinoma in Dimethylhydrazine-treated Rats Varies in a Sitespecific Manner and Depends on Tumor Histology. Cancer Res. v. 57, p. 4507-4510, 1997.

PARMIGIANI, R. B.; CAMARGO, A. A. O genoma humano e o câncer. In: FERREIRA, C. G.; ROCHA, J. C. Oncologia Molecular. São Paulo: Atheneu, 2004.

PAUlSEN, J. E. , LOBERG, E. M. , OlSTORN, H. B., KNUTSEN, H., STEFFENSEN, I. L, ALEXANDER, J. Flat dysplastic aberrant crypt foci are related to tumorigenesis in the colon of azoxymethane-treated rat. Cancer Res. v.65(1), p.1219, 2005.

PEFFLEY, D. M., GAYEN, A. K. Plant-derived monoterpenes suppress hamster kidney cell 3-hydroxy-3-methylglutaryl coenzyme a reductase synthesis at the posttranscriptional level. J. Nutr., v. 133, p. 38-44, 2003. 
PITOT, H. C., DRAGAN, Y. P, TEEguaRDEN, J., HSIA, S., CAMPBELL, H. Quantitation of multiestage carcinogenisis in rat liver. Toxicol. Pathol., v.24, p.119128, 1996.

PITOT, H. C. Pathway of progression in hepatocarcinogenesis. Lancet, v. $358, p$. 859-860, 2001.

POIRIER, M.C. Chemical-induced DNA-damage and human cancer risk. Nat. Rev. Cancer, v.4(8), p.630-637, 2004.

POTTEN, C. S., WILSON, J. W., BOOTH, C. Regulation and significance of apoptosis in the stem cells of the gastrointestinal epithelium. Stem Cells., v. 15, p. 82-93, 1997.

PRETLOW, T. P., BARROW, B. B., ASHTON, W. S. O'RIORDAN, M. A., PRETLOW, T. G., JURCISEK, J. A., STELLATO, T. A. Aberrant crypts: putative preneoplastic foci in human colonic mucosa. Cancer Res., v. 51, p.1564-1567, 1991.

QURESHI, A. A., MANGELS, W. R., DIN, Z. Z., ELSON, C. E. Inhibition of mevalonate biosynthesis by the monoterpene d-limonene. J. Agric. Food. Chem., v. 36, p. $1220-1224,1998$

RAJESHKUMAR, N. V., KUTTAN, R. Modulation of carcinogenic response and antioxidant enzymes of rats administered with 1,2-dimethylhydrazine by Picroliv. Cancer Lett., v. 191, p. 137-143, 2003.

RAJU J., PATLOLLA, J. M. R., SWAMY, M. V., RAO, C. V. Diosgenin, a Steroid Saponin of Trigonella foenum graecum (Fenugreek), Inhibits Azoxymethane-Induced Aberrant Crypt Foci Formation in F344 Rats and Induces Apoptosis in HT-29 Human Colon Cancer Cells. Cancer Epidemiol Biomarkers Prev; v. 13(8), p. 1392-1398, 2004.

RAJU J., SWAMY M. V., COOMA I., PATLOLLA J. M. R., PITTMAN B., REDDY B S., STEELE V. E., RAO C.V. Low doses of _-carotene and lutein inhibit AOM-induced rat colonic ACF formation but high doses augment ACF incidence. Int. J. Cancer., v. 113, p. 798-802, 2005. 
Geraniol, mas nåo beta-ionona ou associaçăo desses isoprenóides, possui atividade quimiopreventiva em ratos submetidos a modelo de carcinogênese de cólon.

RAO, C. V., NEWMARK, H. L., REDDY, B. S. Chemopreventive effect of squalene on colon cancer. Carcinogenesis, v. 19, p. 287-290, 1998.

RAO, C. V., NEWMARK, H. L., REDDY, B. S. Chemopreventive effect of farnesol and lanosterol on colon carcinogenesis. Cancer Detect. Prev., v. 26, p.419-425, 2002.

REDDY, B. S., WANG, C. X., SAMAHA, H., LUBET, R.'STEELE, V. E., KELLOFF, G. J., RAO, C. V. Chemoprevention of colon carcinogenesis by dietary perillyl alcohol. Cancer Res., v. 57, p. 420-25, 1997.

RENEHAN, A. G., O'DWYER, S. T, HABOUBI, N. J., POTTEN, C. S. Early cellular events in colorectal carcinogenesis. Colorectal Disease, v. 4, p. 76-89, 2001.

RODRIGUES, M. A. M., SILVA, L. A. G., SALVADORI, D. M. F. CAMARGO, J. L. V., MONTENEGRO, M. R. Aberrant crypt foci and colon cancer: comparison between a short-and-medium-term bioassay for colon carcinogenesis using dimethylhydrazine in Wistar rats. Braz. J. Med. Biol. Res., v. 35, p. 351-355, 2002.

ROGERS K. J. AND PEGG A. E. Formation of 06-Methylguanine by Alkylation of Rat Liver, Colon, and Kidney DNA following Administration of 1,2 dimethylhydrazine. Cancer Res, v. 37. p. 4082-4087, 1977

RONCUCCI, L., PEDRONI M., VACCINAF., BENATTI P., MARZONA L., DE POL A. Aberrant crypt foci in colorectal carcinoigenesis. Cell and crypt dynamics, Cell Prolif., v. 33, p. 1-18, 2000.

RUPNARAIN, C., DLAMINI, Z., NAICKER, S., BHOOLA, K. Colon cancer: genomics and apoptotic events. Biol Chem. v. 385(6), p. 449-64, 2004.

SENGOTTUVELAN, M., VISWANATHAN, P., NALINI M. Chemopreventive effect of trans-resveratrol - a phytoalexin against colonic aberrant crypt foci and cell proliferation in 1,2-dimethylhydrazine induced colon carcinogenesis. Carcinogenesis., v. 27(5), p. 1038-1046, 2006.

SEVER, N., SONG, B-L, YABE, D., GOLDSTEIN, J. L., BROWN, M. S., et al. Insigdependent ubiquitination and degradation of mammalian 3-hydroxy-3-methylglutaryl 
Geraniol, mas năo beta-ionona ou associaçăo desses isoprenóides, possui atividade quimiopreventiva em ratos submetidos a modelo de carcinogénese de cólon.

CoA reductase stimulated by sterols and geranylgeraniol. J. Biol. Chem., v. 278, p. 52479-52490, 2003.

SHANMUGATHASAN, M., JOTHY, S. Apoptosis, anoikis and their relevance to the pathobiology of colon câncer. Pathol Int. v. 50(4), p. 273-9, 2000.

SHEN, H. M., AND ONG, C. N. Mutations of the p53 tumor suppressor gene and ras oncogenes in aflatoxin hepatocarcinogenesis. Mutat. Res., v. 366, p. 23-44, 1996.

SHIRTLIFF, N., BIRD, R. Growth features of aberrant crypt foci that resist modulation by cholic acid. Carcinogenesis. v.17 (9) p.2093-2096, 1996

SHOFF, S. M., GRUMMER, M., YATVIN. M. B., ELSON, C. E. Concentrationdependent increase of murine P388 and B16 population doubling time by the acyclic monoterpene geraniol. Cancer Res., v.51, p. 37-42, 1991.

SIMKIN. A.J., UNDERWOOD B. A., AULDRIDGE, M., LOUCAS H. M., SHIBUYA, K., SCHMELZ. E., CLARK. D. G., AND KLEE, H. J. Circadian Regulation of the PhCCD1 Carotenoid Cleavage Dioxygenase Controls Emission of beta-lonone, a Fragrance Volatile of Petunia Flowers. Plant Physiology, v. 136, p. 3504-3514, 2004.

SING, V. N., GABY, S. K. Premalignant lesions: role of antioxidant vitamins and $\beta$ carotene in risk reduction and prevention of malignant transformation. Am. J. Clin. Nutr., v.53, p. 386s-90s, 1991.

SONG, G., MAO, Y. B., CAI, F., YAO, L. M., OUYANG, G. L., BAO, S. D. Curcumin induces human HT-29 colon adenocarcinoma cell apoptosis by activating p53 and regulating apoptosis-related protein expression. Braz J Med Biol Res. v. 38(12), p. 1791-1798, 2005.

SOHN, O. S., FIALA, E. S., REQUEIJO, S. P., WEISBURGER, J. H., GONZALEZ, F. $J$. Differential effects of CYP2E1 status on the metabolic activation of the colon carcinogens azoxymethane and methylazoxymethanol. Cancer Res. v. 61(23), p. $8435-40,2001$

SPORN, M. B., DUNLOP, N. M., NEWTON, D. L., SMITH, J. M. Prevention of chemical carcinogenesis by vitamin $A$ and its synthetic analogs (retinoids). Fedn. Proc., v. 35, p. 1332-1338, 1976. 
STAYROOK, K. R., MCKINZIE, J. H., BURKE, Y. D., BURKE, Y. A., CRONE!!, D Induction of the apoptosis-promoting protein Bak by perillyl alcohol in pancreatic ductal adenocarcinoma relative to untransformed ductal epithelial cells. Carcinogenesis v.18(8), p.1655-1658, 1997.

SUÁREZ, Y., FERNÁNDEZ, C., LEDO, B., MARTÍN, M., GÓMEZ-CORONADO, D., LASUNCIÓN, M. A. Sterol stringency of proliferation and cell cycle progression in human cells. Biochim Biophys Acta. v. 1734(2), p. 203-13.

SURH, Y. J. Cancer chemoprevention with dietary phytochemicals. Nature Reviews Cancer. v. 3, p. 768-780, 2003

TAKEDA Y, NAKAO K, NAKATA K, KAWAKAMI A, IDA H, ICHIKAWA T, SHIGENO M, KAJIYA Y, HAMASAKI K, KATO Y, EGUCHI K. Geranylgeraniol, an intermediate product in mevalonate pathway, induces apoptotic cell death in human hepatoma cells: death receptor-independent activation of caspase-8 with down-regulation of Bcl-xL expression. Jpn. J. Cancer Res. v. 92(9), p. 918-25, 2001.

TANAKA, T. AND MORI,H. Inhibition of colon carcinogenesis by nonnutritive constituents in foods. J. Toxicol. Pathol., v. 9, p. 139-149, 1996.

TATMAN, D., MO, H. Volatile isoprenoid constituents of fruits, vegetables and herbs. cumulatively suppress the proliferation of murine b16 melanoma and human HL-60 leukemia cells. Cancer Lett., v.175, p. 129-139, 2002.

TOLEDO, L. P., ONG, T. P., PINHO, A. L. G., JORDĀO Jr, A. A., VANUCCHI, H., MORENO, F. S. Inhibitory effects of lutein and lycopene on placental glutathione Stransferase positive preneoplastic lesions and DNA strand breakage induced in Wistar rats by the resistant hepatocyte model of hepatocarcinogenesis. Nutr. Cancer, v. 47, p. 62-69, 2003.

THIERY-VUILLEMIN A., NGUYEN T., PIVOT $X$., SPANO J. P., DUFRESNNE A., SORIA J. C., Molecularly targeted agents: Their promise as cancer chemopreventive interventions. Eur. J. Cancer v.41, p. 2003-2015, 2005

VANAMALA, J., LEONARDI, T., PATIL, B. S., TADDEO, S. S., MURPHY M. E., PIKE, L. M., CHAPKIN, R. S. LUPTON, J. R., TURNER, N. D. Suppression of colon 
carcinogenesis by bioactive compounds in grapefruit. Carcinogenesis., v. 27, n. 6 , p. $1257-1265,2006$

VENITT, S. Mechanisms of carcinogenesis and individual susceptibility to cancer. Clin. Chem., v.40, p. 1421-1425, 1994.

VOLATE, S. R., DAVENPORT, D. M., MUGA, S. T., WARGOVICH, M. J. Modulation: of aberrant crypt foci and apoptosis by dietary herbal supplements (quercetin, curcumin, silymarin, ginseng and rutin). Carcinogenesis., v. 26(8), p. 1450-1456, 2005.

VOZIYAN, P. A., HAUG, J. S., MELNYKOVYCH, G. Mechanisms of farnesol cytotoxicity: Further evidence for the role of PKC-dependent signal transduction in farnesol - induced apoptotic cell death. Biochem. Biophys. Res. Commun., v. 212, p. $479-486,1995$.

WALI R. K., KHARE S., TRETIAKOVA M., COHEN G., NGYEN L., HART J., WANG J., WEN M., RAMASWAMY a, JOSEPH L., SITRIN M., BRASITUS T. and BISSONNETTE M. Ursodeoxycholic Acid and F6-D3 Inhibit Aberrant Crypt Proliferation in the Rat Azoxymethane Model of Colon Cancer: Roles of Cyclin D1 and E-Cadherin, Cancer Epidemiology, Biomarkers, Prevention, v. 11, 1653$1662,2002$.

WARGOVICH, M. J., JIMENEZ, A., MCKEE, K., STEELE, V. E., VELASCO, M., WOODS J., PRICE, R., GRAY, K., KELLOFF G. J. Efficacy of potential chemopreventive agents on rat colon aberrant crypt formation and progression. Carcinogenesis, v. 21, p. 1149-1155, 2000.

WONG, C. S. M., GIBSON, P. R. The trophic effect of dietary fibre is not associated with a change in total crypt number in the distal colon of rats. Carcinogenesis., v. 24(2), p. 343-348, 2003.

WU, B., IWAKIRI, R., OOTANI, a , TSUNADA, S., FUJISE, T., SAKATA, Y., SAKATA, H., TODA, S., FUJIMOTO, K. Dietary corn oil promotes colon cancer by inhibiting mitochondria-dependent apoptosis in azoxymethane-treated rats. Exp. Biol. Med. 229:1017-1025, 2004.

YOUNG, M. R., YANG, H-S., COLBURN, N. H. Promising molecular targets for cancer prevention: AP-1, NF-kB and Pdcd4. Trends in Molec. Med.., v. 9., p. 36-41, 2003. 
YU, S. G., ABUIRMEILEH, N. M., QURESHI, A. A., ELSON, C. E. Dietary $\beta$-ionone suppresses hepatic 3-hidroxy-3-methylglutaryl coenzyme A reductase activity. J. Agric. Food. Chem., v. 42, p. 1493-1496, 1994.

YU, S. G., ANDERSON, P. J., ELSON, C. E. Efficacy of $\beta$-ionone in the chemoprevention of rat mammary carcinogenesis. J. Agric. Food. Chem., v. 43, p. 2144-2147, 1995.

YU, S. G., HILDEBRANDT, L. A., ELSON, C. E. Geraniol, an inhibitor of mevalonate biosynthesis, supress the growth of hepatomas e melanomas transplanted to rats and mice. J. Nutr., v. 125, p. 2763-2767, 1995.

ZHENG Y., KRAMER M., LUBET R.A., STEELE V. E., KELLOFF G. J., PEREIRA M. A. Effect of retinoids on AOM-induced colon cancer in rats: modulation of cell proliferation, apoptosis and aberrant crypt foci. Carcinogenesis, v. 20, p. 255-260, 1999. 
Geraniol, mas năo beta-ionona ou associaçăo desses isoprenóides, possui atividade quimiopreventiva em ratos submetidos a modelo de carcinogénese de cólon.

\section{VIII- ANEXOS OBRIGATÓRIOS}




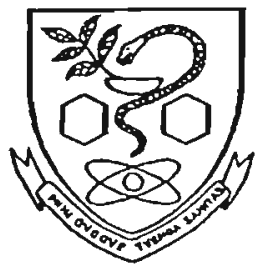

UNIVERSIDADE DE SÃO PAULO

Faculdade de Ciências Farmacêuticas Comissão de Ética em Experimentação Animal

\section{DEE $\underline{E} \underline{\operatorname{A}} \underline{\mathrm{R}} \underline{\mathrm{A}} \underline{\mathrm{A}} \underline{\mathrm{A}} \underline{\mathrm{V}}$}

Declara, para os devidos fins, que a projeto "Avaliaçáa da eventual atividade quimiapreventiva das isoprenáides $\beta$-innona $e$ geranial quanda administrados isaladamente ou em conjunto em ratos Wistar durante as etapas de iniciação de pós-iniciaçáo de madela de carcinagênese de cólon" (Protıcolo CEEA n 75), da(o) pesquisadar(a) Alessandra Vieira, sab orientação de Fernando Salvador Moreno, está tramitando junto à Comissão de Ética em Experimentação Animal da Faculdade de Ciências Farmacêuticas da Universidade de Sãa Paulo.

São Paula, 06 de julho de 2005.

$$
\text { Elfiede baceli }
$$

Profa. Assuc. Elfriede Marianne Bacchi

Presidente da Camissãa de Ética em Experimentaçãa Animal FCF/USP 